\title{
A Global Institution on Animal Protection
}

\author{
Carolina Fumagalli \\ Master in Animal Law and Society (UAB) \\ ORCID: 0000-0001-5706-2753
}

Received: February 2020

Accepted: May 2020

Recommended citation. FUMAGALLI, C., A Global Institution on Animal Protection, dA. Derecho Animal (Forum of Animal Law Studies) 11/2 (2020). - DOI https://doi.org/10.5565/rev/da.482

\begin{abstract}
This work addresses the need for a global public institution in favour of animals. In particular, it focuses on the design of a new international organization on animal protection by taking into consideration three models: the EU Platform on Animal Welfare, the United Nations Environment Programme (UNEP) and the United Nations Forum on Forests (UNFF). Referring to these models, the mandate of the organization on animal protection is drafted, membership and participation criteria are considered, as well as its mechanisms of functioning. The collaboration with other international organizations is foreseen, and common fields of interest are identified. Particular attention is dedicated to the transition towards an economic and sustainability model that considers animals as sentient living beings with fundamental interests in the preservation of their life and dignity, rather than as exploitable resources. In order to address the current global challenges related to animal protection, and progress towards effective universal rights (not only for humans), the creation of a public international institution on animal protection is needed.
\end{abstract}

Key words: animal protection; international organizations; global governance; animal rights.

Resumen - Una institución pública global a favor de los animales

Este trabajo aborda la necesidad de una institución pública global a favor de los animales. En particular, se centra en la definición de una nueva organización internacional para la protección de los animales teniendo en cuenta tres modelos: la Plataforma de la UE sobre Bienestar Animal, el Programa de las Naciones Unidas para el Medio Ambiente (PNUMA) y el Foro de las Naciones Unidas sobre los Bosques (UNFF). En referencia a estos modelos, se redacta el mandato de la organización sobre protección animal, se consideran los criterios de membresía y participación, así como sus mecanismos de funcionamiento. Además, se prevé la colaboración con otras organizaciones internacionales y se identifican campos de interés comunes. Se presta especial atención a la transición hacia un modelo económico y sostenible donde los animales son considerados seres vivos con intereses fundamentales en la preservación de su vida y dignidad, en lugar de recursos explotables. Para abordar los desafíos globales actuales relacionados con la protección animal y avanzar hacia unos derechos universales efectivos (no sólo para los seres humanos), se necesita la creación de una institución pública global a favor de los animales.

Palabras clave: protección animal; organización internacional; gobernanza global; derechos de los animales. 


\section{Index of abbreviations}

\begin{tabular}{|c|c|}
\hline $\mathrm{BRC}$ & British Retail Consortium \\
\hline B2B & Business to Business \\
\hline $\mathrm{B} 2 \mathrm{C}$ & Business to Consumers \\
\hline CBD & Convention on Biological Diversity \\
\hline CITES & Convention on International Trade in Endangered Species of Wild Fauna and Flora \\
\hline CMS & Convention on the Conservation of Migratory Species of Wild Animals \\
\hline $\mathrm{CoE}$ & Council of Europe \\
\hline $\mathrm{COP}$ & Conference of the Parties \\
\hline $\mathrm{CPF}$ & Collaborative Partnership on Forests \\
\hline CSD & Commission on Sustainable Development \\
\hline DELC & Division of Environmental Law and Conventions \\
\hline DPI & Department of Public Information \\
\hline DSB & Dispute Settlement Body of the World Trade Organization \\
\hline ECOSOC & United Nations Economic and Social Council \\
\hline ESES & Environmental, Social and Economic Sustainability Framework \\
\hline EU & European Union \\
\hline FAO & Food and Agriculture Organization of the United Nations \\
\hline GATT & General Agreement on Tarif and Trade \\
\hline GEO & Global Environmental Outlook \\
\hline GFSI & Global Food Safety Initiative \\
\hline GlobalG.A.P. & Global Good Agricultural Practices \\
\hline IARC & International Agency for Research on Cancer \\
\hline ICRW & International Convention for the Regulation of Whaling \\
\hline IFC & International Finance Corporation \\
\hline IFF & Intergovernmental Forum on Forests \\
\hline IFS & International Featured Standards \\
\hline IHR & International Health Regulations \\
\hline IPCC & Intergovernmental Panel on Climate Change \\
\hline IPF & Intergovernmental Panel on Forests \\
\hline MAD & Mutual Acceptance of Data \\
\hline MEA & Multilateral Environmental Agreement \\
\hline MOP & Meeting of the Parties \\
\hline NCP & National Contact Point \\
\hline NFACC & National Farm Animal Care Council \\
\hline OECD & Organisation for Economic Co-operation and Development \\
\hline OIE & World Organisation for Animal Health \\
\hline PETA & People for the Ethical Treatment of Animals \\
\hline PVS & Performance of Veterinary Services \\
\hline SDGs & Sustainable Development Goals \\
\hline SPS & Agreement on the Application of Sanitary and Phytosanitary Measures \\
\hline SQF & Safe Quality Food \\
\hline TNC & Transnational Corporation \\
\hline UDAW & Universal Declaration on Animal Welfare \\
\hline UN & United Nations \\
\hline UNEP & United Nations Environment Programme \\
\hline UNEO & United Nations Environmental Organization \\
\hline UNFF & United Nations Forum on Forests \\
\hline VISC & Voluntary Indicative Scale of Contributions \\
\hline WHO & World Health Organization \\
\hline WTO & World Trade Organization \\
\hline
\end{tabular}




\section{Table of contents}

1. Introduction

2. An international institution to respond to the need for a holistic, centralized, global approach to animal protection

3. Existing reference models

4. A Global institution for animal protection

5. Conclusions

\section{Introduction}

Animal protection is often associated with animal welfare, species conservation, rules about the use of animals in research, welfare and health of animals used in food production. Those are components of a wider and deeper concept of protection which, in analogy with human rights, is intended as protection of animals' dignity and interest in the preservation of their life and fundamental rights. ${ }^{1}$ The philosophical approaches rejecting speciesism and overcoming the anthropocentric dogma in ethics provide a solid ground for extending the legal protection of fundamental rights to animals, and for considering animals' interests as morally relevant issues in the public discourse. Although many states have progressive regulations and relatively high standards on animal protection, ${ }^{2}$ others do not take animals in any consideration. ${ }^{3}$ At national law level, there is a very diverse and non-homogeneous set of rules about animals; that means that among states there is no consensus on the legal status of animals, nor on minimum standards of protection of their fundamental rights and dignity. This is reflected in international law, where the few existing instruments on animals are limited to specific aspects, for example species conservation, ${ }^{4}$ animal health and zoonosis, ${ }^{5}$ transport of live animals, ${ }^{6}$ etc. A

\footnotetext{
${ }^{1}$ Animals are living beings with an interest in self-preservation (both as species as well as single individuals) and in self-determination according to their natural and ethological inclinations. Recalling Schweizter concept of "life that wills to live", Tom Regan defines animals as "subjects of a life" with the same degree of "inherent value" which should be respected, see REGAN, T., The case for animal rights (Berkeley 1983) 241- 243.

${ }^{2}$ For example Switzerland has recognized the protection of dignity of living beings as a federal constitutional principle. Article 120 , para. 2 of the Swiss Federal Constitution was approved in 1992 and reads as follow: "The Confederation shall legislate on the use of reproductive and genetic material from animals, plants and other organisms. In doing so, it shall take account of the dignity of living beings as well as the safety of human beings, animals and the environment, and shall protect the genetic diversity of animal and plant species". For further information about dignity protection in Switzerland see BOLLIGER, G., Animal Dignity Protection in Swiss Law - Status Quo and Future Perspectives (Zürich, Basel, Geneva 2016).

${ }^{3}$ About the different national legislations regulating animal related issues see Global Animal Law Project Database Legislation. Webpage: https://www.globalanimallaw.org/database/national/index.html [Retrieved July 13, 2019].

${ }^{4}$ See Convention on International Trade in Endangered Species of Wild Fauna and Flora (CITES) (adopted March 3, 1973) 993 UNTS 243; Convention on the Conservation of Migratory Species of Wild Animals (CMS) (adopted June 23, 1979) 1651 UNTS 333.; Convention on Biological Diversity (CBD) (adopted June 5, 1992) 1760 UNTS 79.

${ }^{5}$ The original mandate of the International Organization for Animal Health (OIE) focused on animal health and the prevention of the spread of animal diseases to humans. It was later expanded to animal welfare, see OIE, Global Animal Welfare Strategy. Webpage: http://oie.int/en/for-the-media/press-releases/detail/article/adoption-of-the-first-oie-global-strategy-on-animal-welfare [Retrieved April 19, 2020]. OIE also support the "One Welfare" initiative, which aims to "highlight the interconnections between animal welfare, human wellbeing and the environment. It fosters interdisciplinary collaboration to improve human and animal welfare internationally." ONE WELFARE, About One Welfare. Webpage: https://www.onewelfareworld.org/about.html [Retrieved October 2, 2019]. About the involvement of OIE in "One Welfare" see OIE, Bulletin, Animal welfare: an Asset for Livestock Production (2017). Webpage: https:/www.oie.int/fileadmin/Home/eng/Publications_\&_Documentation/docs/pdf/bulletin/Bull_2017-1-ENG.pdf [Retrieved October 2, 2019].

${ }^{6}$ OIE, Terrestrial Animal Health Code. Webpage: http://www.oie.int/en/standard-setting/terrestrial-code/access-online/ [Retrieved June 20, 2019]; Council of Europe, European Convention for the Protection of Animals during International Transport (Revised) (adopted November 6, 2003) ETS No.193.
}

64 Derecho Animal. Forum of Animal Law Studies, vol. 11/2 
consensus about animal welfare ${ }^{7}$ as a general principle of international law is emerging. ${ }^{8}$ However, a overarching treaty or declaration about the core principles of animal protection is lacking when it is most needed. The impellent necessity of a wider regulation beyond domestic jurisdiction ${ }^{9}$ and affirmation of principles of protection is due to the fact that animal protection is intrinsically a global phenomenon deeply intertwined with economic interests. Animal protection faces challenges that, in the current globalised society and economic model, transcend territorial borders. ${ }^{10}$ Transnational Corporations (TNCs) operating in the food supply chain consider animals as units of production ${ }^{11}$ to which apply the economic principle of efficiency, rather than the legal and ethical value of protection. In order to maximise efficiency and consequently profits, TNCs tend to invest where regulations are more permissive and social and cultural consideration of animals is weak. ${ }^{12}$ This situation prompts states to compete with each other to obtain TNCs' investments on their territory at the cost of lowering animal protection standards with consequent dumping effect and a typical race to the bottom. ${ }^{13}$ Charlotte Blattner in her book "Protecting Animals Within and Across Borders: Extraterritorial Jurisdiction and the Challenges of Globalization" has investigated the use of extraterritorial jurisdiction as a way to address animal law issues across borders and guarantee animal protection in a globalized society. ${ }^{14}$ This thesis proposes a complementary strategy to face the demand for a global response to animal protection challenges: the creation of a global institution for animal protection. An institution with a global or international dimension could be defined as "formally agreed sets of rules regulating cooperation and conflict among state and non-state global actors, some of which also provide for the creation of international organisations (IOs) and/or are applied by IO bureaucracies". ${ }^{15}$ According to this definition, international institutions could take the form of less structured international regimes, formally negotiated treaties, or stable international organisations. ${ }^{16}$ This work focuses on the establishment of a global institution in the form of an international organization. ${ }^{17}$

This study introduces the creation of a global institution for animal protection as a new topic of research. Whilst the academic debate focuses mainly on animal law, this work suggests an "animal protection

\footnotetext{
${ }^{7}$ OIE, Terrestrial Animal Health Code. Art. 7.1.1 of OIE Terrestrial Animal Health Code provides the following definition of animal welfare: "Animal welfare means how an animal is coping with the conditions in which it lives. An animal is in a good state of welfare if (as indicated by scientific evidence) it is healthy, comfortable, well nourished, safe, able to express innate behaviour, and if it is not suffering from unpleasant states such as pain, fear, and distress. Good animal welfare requires disease prevention and veterinary treatment, appropriate shelter, management, nutrition, humane handling and humane slaughter/ killing. Animal welfare refers to the state of the animal; the treatment that an animal receives is covered by other terms such as animal care, animal husbandry, and humane treatment". OIE, Supra note 6.

${ }^{8}$ BLATTNER, C. E., Protecting Animals Within and Across Borders: Extraterritorial Jurisdiction and the Challenges of Globalization (New York 2019) 76-77. Anti-cruel and animal welfare laws are in place in many legal systems across the world with a very diverse degree of protection and limitation of human treatment of animals. A Canadian court has defined anti-cruelty law as a "rule of civilization", see Court of Appeal of Alberta, Reece v. Edmonton (City), 238 (CanLII) (Aug 04, 2011), para. 56. Webpage: https://www.canlii.org/en/ab/abca/doc/2011/2011abca238/2011abca238.html\#_ftn28 [Retrieved: 19 April 2019]. Some scholars argue that animal welfare constitutes "a 'general principle of law' in the sense of Article 38 of the Statute of the International Court of Justice”, see PETERS, A., Global Animal Law: What It Is and Why We Need It, Transnational Environmental Law, 5(1) (2016), 9-23, p. 12. DOI: https://doi.org/10.1017/S2047102516000066.

${ }^{9}$ Ibid. PETERS, at 13.

${ }^{10}$ PETERS, A., Introduction to Symposium on Global Animal Law (Part I): Animals Matter in International Law and International Law Matters for Animals, AJIL Unbound, 111 (2017), 252-256, p. 254. DOI: https://doi.org/10.1017/aju.2017.70; BLATTNER, C. E., The Potential and Potential Limits of International Law in Regulating Animal Matters, 3 Mid-Atlantic Journal on Law and Public Policy, 10 (2015), 10-55, p. 23-24. As Blattner has noted: "It generally can be stipulated that there are two main factors accounting for the categorization of animal matters on either level of regulation - namely the nature of the problem and the nature of the animal. [...]The nature of the problem [..] hints at the internationalization of how animals are bred, raised, slaughtered, processed, packaged, etc. The nature of the animal, on the other hand, sparks international attention, as animals may be migratory or otherwise considerably moved around by humans. The two factors are closely related as they bring about global character to the issue at hand: Global goods require global regulation".

${ }^{11}$ See KELCH, T. G., Globalization and Animal Law: Comparative Law, International Law, and International Trade (Alphen aan den Rijn 2011) 23.

12 BLATTNER, supra note 8 , at 53.

${ }^{13}$ Ibid., at 3; PETERS, supra note 8 , at 18 .

14 Ibid., BLATTNER, at 55.

${ }^{15}$ FEHL, C., FREISTEIN, K., (Un)making Global Inequalities: International Institutions in a Stratified International Society, Journal of International Relations and Development, (2020). DOI: https://doi.org/10.1057/s41268-020-00190-z.

16 Ibid.

${ }^{17}$ An international organization is an intergovernmental organization usually created by states through a founding treaty. KLABBERS, J., International Law (Cambridge 2017) 90. According to Alvarez, some of the defining features of IOs are: genuine international aims, composed by states, which contribute to the budget; membership with full voting rights open to states; single national groups should not exert control over others; existence of governing bodies, independent officers of different nationalities and a permanent headquarters; IO should act independently and elect its own officials; evidence of its activities must be available. ALVAREZ, J., International Organizations as Law-makers (Oxford 2005) 4-6. About the constitutive elements of IOs see SCHERMERS, H.G., BLOKKER, N.M., International Institutional Law: Unity within Diversity (Leiden 2011) 37.
} 
governance" approach complementary to the legal discourse. Animal protection has a peculiar global dimension ${ }^{18}$ that urges an adequate governance structure. ${ }^{19}$ At present, animals interests are underrepresented in IOs. The existing international institutions dealing with animals lack an overarching approach to fundamental principles of protection of animal dignity, rights and interests. The proposal for the establishment of a global institution on animal protection would strengthen the animal governance tools currently available. Gradually, the work of the proposed organization could change the cultural consideration of animals on a global level by creating the conditions for a new shared conception of animals as living beings whose life, dignity, and fundamental interests are worthy of protection and representation in public institutions. The final goal is to concretely provide mechanisms of protection through the establishment of a stable institutional apparatus and set of rules specifically for this purpose.

The question that will guide the investigation is how a global institution for animal protection could be created in legal and governance terms. In the first part of the work, the global dimension of animal protection and the need for a dedicated international organization will be clarified. The second part will analyse the reference models of three existing institutions: the EU Platform on Animal Welfare, UN Environment Programme (UNEP), and UN Forum on Forests (UNFF). In the third part, the characteristics of the proposed organization in favour of animals will be outlined, and its mandate and goals will be defined, as well as the possible competences, structure, members and partners, and mechanisms of functioning.

\section{An international institution to respond to the need for a holistic, centralized, global approach to animal protection}

Animal protection is an interdisciplinary concept ${ }^{20}$ characterized by complex and interdependent components, that should be approached from a global, comprehensive, and holistic standpoint. Such an approach does not exist today. Various aspects of animal protection have been developed independently of each other without any common guiding principle. A new comprehensive perspective has to be found, one that could match the complexity of the topic and provide tools of governance and legal regulation to adequately respond to existing global challenges. The creation of a global institution capable to create order and indicate fundamental general principles appears imperative in order to deal in an effective manner with this multifaceted topic. International animal protection norms are quite fragmented. Moreover, the actions of the several actors involved in the various components of animal protection are uncoordinated and their effectiveness is not maximized. This fragmentation is due to the absence at international level of a leading institution on animal protection governance, that could act as hub for initiatives in favour of animals, provide an overarching approach to animal protection fundamental principles focusing on dignity and rights, guarantee technical support, centralize coordination, and encourage cooperation among all actors involved.

Why global? Because animal related issues do not know borders or states' limitations, ${ }^{21}$ and economic interests behind the exploitation of animals in various industry sectors are intrinsically global phenomena whose environmental and social consequences affect the entire world. Livestock sector has huge negative consequences on habitat and ecosystems conservation, pollution and climate change, ${ }^{22}$ land degradation, use

\footnotetext{
${ }^{18}$ BLATTNER, supra note 10 , at 24 .

${ }^{19}$ As it will be clarified in section 2, animal protection is a global governance issue. According to the definition provided by Karen Mingst: "Global governance encompasses activities at all levels of human interaction that have international repercussions. It implies examination of various governance activities, from formal to informal, from law to rules to understandings, at a variety of locales. [..] New forms of global governance are emerging as prominent pieces of international relations. Such forms include nongovernmental organizations, transgovernmental coalitions, members of various expert communities, and participants in international regimes". MINGST, K., Essentials of International Relations (New York 2001) 241. Animal protection has a transnational feature and international repercussions, it is regulated by formal laws, treaties, but also by principles and soft law rules, moreover a plurality of transnational non-state actors are involved. About the recent debate on the definition of global governance see KASPER, A.E.P., Global Governance 2.0. In: M. HOSLI, J. SELLESLAGHS (eds) The Changing Global Order. United Nations University Series on Regionalism, vol 17 (2020). Springer, Cham. DOI https://doi.org/10.1007/978-3-030-21603-0 14.

${ }^{20}$ Some of the disciplines involved in animal protection are: law (legal protection and consideration of animals as potential holders of rights and interests), economy (trade, use of animals in many economic sectors and its balance with a certain standards of animal welfare), health (consequences of the consumption of animals, food security, new diseases derived from animal germs, antimicrobial resistance), sustainable development and environment (impact of animal exploitation in terms of pollution, exploitation of resources, impact on ecosystems), biology, and philosophical, sociological and psychological aspects of the relation between human and nonhuman animals (violence, use of media, anthropocentrism and speciesism).

${ }^{21} \mathrm{KELCH}$, supra note 11 ; BLATTNER, supra note 10.

${ }^{22}$ Livestock contributes to air and water pollution and to greenhouse gas emissions through digestive process, manure, and indirectly through the livestock supply chain (production and transportation of feed, animals transportation to slaughterhouses, cooling, storage and processing of livestock products). The use of pesticides in production of feed also contributes to pollution and environmental risks. STEINFELD, H., GERBER, P., WASSENAAR, T., CASTEL, V., ROSALES, M., \& DE HAAN, C., Livestock's Long Shadow, Environmental Issues and Options, (2006), chapter 3 and 4. Webpage: http://www.fao.org/3/a0701e/a0701e00.htm [Retrieved July 8, 2019]. FAO, Shaping the Future of Livestock Sustainably, Responsibly, Efficiently (The 10th Global Forum for Food and Agriculture 66 Derecho Animal. Forum of Animal Law Studies, vol. 11/2
} 
of water, land and waste of resources, ${ }^{23}$ deforestation and loss of biodiversity, ${ }^{24}$ not to mention the public health considerations ${ }^{25}$ about antibiotic resistance, ${ }^{26}$ and the health consequences of consumption of meat, ${ }^{27}$ dairy products ${ }^{28}$ and eggs. In many regions of the world, especially in south America and Sub-Saharan Africa, the intensive production of forage for animal farming contributes to land grabbing and degradation to the detriment of forests and biodiversity and with negative consequences for small farmers. ${ }^{29}$ Economic interests of TNCs controlling food industry and the use of animals in research are two aspects of animal protection particularly concerned with the possibility of being outsourced from countries with high animal protection standards to countries where animal protection is underregulated. ${ }^{30}$ In order to promote animal protection, avoiding economic, ethical and social dumping effects and forestalling an economic race to the bottom, the approach has to be as wide as possible. Domestic or regional initiatives and regulations can be very useful in addressing peculiar problems of a specific territory and can contribute to spread and enhance the value of animal protection locally. However, they do not solve the problem of regulatory competition among different juridical systems toward a "lower common denominator" or race to the bottom. ${ }^{31}$ Considering the complexity of the topic and the interdependency of our globalized society, the ultimate solution has to be global in order to properly address the need for a comprehensive and coherent approach. A global institution in favour of animals could help in filling the current gaps in international animal law and governance. This institution would contribute to the promotion of international agreements among its members and it would be a permanent forum for debate, participation, coordination, negotiation, enhancement of knowledge and expertise. It could resume and coordinate initiatives such as the private business governance formats on animal welfare and the various Non-Governmental Organizations (NGOs) declarations ${ }^{32}$ and projects. ${ }^{33}$ Animal

GFFA), (2018, January), p.9. Webpage: http://www.fao.org/3/i8384en/I8384EN.pdf [Retrieved August 17, 2019].

${ }^{23}$ The production of $1 \mathrm{~kg}$ of meat requires in average $3 \mathrm{~kg}$ of cereals and $16000 \mathrm{l}$ of water, see NELLEMANN, C., MACDEVETTE, M., MANDERS, T., EICKHOUT, B., SVIHUS, B., PRINS, A. G., \& KALTENBORN, B. P., The Environmental Food Crisis - The Environment's Role in Averting Future Food Crises. A UNEP Rapid Response Assessment. United Nations Environment Programme, GRID-Arendal, (2009), p 26; see also FAO, supra note 22. The use of land for feed production competes with the production of food for human consumption. Livestock sector (including feed crop production) alone was using $30 \%$ of ice-free world land, this percentage is expected to grow given that the demand and consumption of products derived from animal farming will increase by $70 \%$ by 2050 according to FAO forecasts. See STEINFELD, supra note 22, at 4; FAO, Livestock and the Environment. Webpage: http://www.fao.org/livestock-environment/en/ [Retrieved July 7, 2019].

${ }^{24}$ Agriculture is the second cause of biodiversity loss after overexploitation; in particular crop and livestock farming are the sectors with the greatest impact. Habitat change, climate change, invasive alien species, overexploitation and pollution are major biodiversity loss drivers. Livestock contributes to all these drivers. STEINFELD, supra note 22, at 4-6, 24, 182, and 187; MAXWELL, S. L., FULLER, R. A., BROOKS, T. M., WATSON, J. E., Biodiversity: The Ravages of Guns, Nets and Bulldozers, (2016, August 10). Webpage: https://www.nature.com/news/biodiversity-the-ravages-of-guns-nets-and-bulldozers-1.20381 [Retrieved August 17, 2019]. ${ }^{25}$ Public health is affected by the use of animals for food production because of the risks of zoonotic diseases (such as the swine fever and avian influenza) and antimicrobial resistance. FAO, supra note 22, at 7.

${ }^{26}$ MARSHALL, B. M., LEVY, S. B., Food Animals and Antimicrobials: Impacts on Human Health. Clinical Microbiology Reviews, 24(4) (2011) 718-733, DOI: https://doi.org/10.1128/CMR.00002-11; WHO, Antimicrobial Resistance. Webpage: https://www.who.int/en/news-room/fact-sheets/detail/antimicrobial-resistance. [Retrieved October 7, 2019].

27 The International Agency for Research on Cancer (IARC) classifies red meat as probably carcinogenic to humans (class 2A) and processed meat as carcinogenic to humans (class 1). IARC, Monographs on the Identification of Carcinogenic Hazards to Humans, (2019). Webpage: https://monographs.iarc.fr/list-of-classificationsm [Retrieved August 10, 2019]. In particular IARC affirms that there are sufficient evidences to associate the consumption of processed red meat with the colon and rectum cancer, see IARC, List of Classifications by Cancer Sites with Sufficient or Limited Evidence in Humans, Volumes 1 to 124, (2019, July 8). Webpage: https://monographs.iarc.fr/wp-content/uploads/2019/07/Classifications by cancer site.pdf [Retrieved October 7, 2019]. About carcinogenicity of red meat and processed meat see BOUVARD, V., LOOMIS, D., GUYTON, K. Z., GROSSE, Y., GHISSASSI, F., BENBRAHIM-TALLAA, L., \& al., Carcinogenicity of Consumption of Red and Processed Meat, Lancet Oncology, 16, (2015), 15991600. DOI: https://doi.org/10.1016/S1470-2045(15)00444-1. Processed meat is linked to higher risk of coronary heart disease, stroke and type 2 diabetes, see MICHA, R., WALLACE, S. K., \& MOZAFFARIAN, D., Red and Processed Meat Consumption and Risk of Incident Coronary Heart Disease, Stroke, and Diabetes Mellitus: A Systematic Review and Meta-Analysis, Circulation, 121 (2010), 2271-2283. DOI: https://doi.org/10.1161/CIRCULATIONAHA.109.924977.

28 WILlETT, W. C., LUDWIG, D. S., Milk and Health, New England Journal of Medicine, 382 (2020), 644-54. DOI: https://doi.org/10.1056/NEJMra1903547.

${ }^{29}$ ALEXANDER, S., DUDLEY, N., The Global Land Outlook. Bonn: United Nations Convention to Combat Desertification, (2017), p. 8 .

${ }^{30}$ BLATTNER, supra note 8, at 59-60 and 65-66.

${ }^{31}$ Ibid.

${ }^{32}$ See the Declaration of Animal Rights proclaimed in 1978 by the International League of Animal Rights at the UNESCO headquarters in Paris; NEUMANN, J.M., The Universal Declaration of Animal Rights or the Creation of a New Equilibrium Between Species, Animal Law (19) (2012), 91-109. Another project is the Universal Declaration on Animal Welfare (UDAW), see Global Animal Law Project Draft Declaration on Animal Welfare at Universal Level UDAW Proposal. Webpage: https://www.globalanimallaw.org/database/universal.html [Retrieved August 28, 2019]. Other initiatives are the Declaration for Cetaceans Rights and the Great Apes Project.

${ }^{33}$ The Non-human Rights Project seeks to obtain recognition of legal personhood for animals and enforcement of some of their fundamental rights, see Non-human Rights Project. Webpage: https://www.nonhumanrights.org/ [Retrieved April 19, 2019$].$ 
protection has recently gained consideration in many International Organizations (IOs) such as the World Trade Organization (WTO), ${ }^{34}$ the World Organisation for Animal Health (OIE),${ }^{35}$ the Food and Agriculture Organization (FAO) of the United Nations, and the World Health Organization (WHO). ${ }^{36}$ The main focus of WTO, FAO and WHO is clearly not on animals, therefore they are not apt to take over the responsibility to properly represent animal interests. An institution specialized on animal protection would better coordinate the efforts of other IOs whose mandate is not directly related to animals but which have collateral activities or interests affecting animal protection. OIE and the proposed organization on animal protection might be perceived has having overlapping area of work, however their scope and type of actions are different. OIE focuses on technical aspects of animal health and welfare, which can be considered components, among others, of animal protection. Animal protection is a broader concept that includes animal health and welfare but it is not entirely reducible to them. OIE mandate does not extend beyond these two themes and its actions do not engage in discussion about general principles of protection and representation of animal interests.

The global approach concerns also the types of actors involved. This institution would respond to the need for concerted actions and collaboration among all actors that are somehow involved with the various components of animal protection. States play a key role in the international arena since they hold the constitutive power in international law. ${ }^{37}$ Non-state actors such as IOs, NGOs, civil society movements, and business representatives are gaining more and more influence in current international relations, and are today new active players in defining international policies and norms. ${ }^{38}$ The proposed institution for animal protection would support multilateral cooperation among state and non-state actors for the definition of a global unitary framework of socio-legal rules, principles, and values of animal protection. ${ }^{39}$ This institution aims to provide a point of reference for other international agencies that are somehow concerned with animal related issues. It would also advance animal advocacy by raising public awareness and influencing changes in the cultural attitude towards animals at domestic and regional level. ${ }^{40}$

In May 2018 the EU Parliament adopted a resolution asking for a global ban on cosmetic testing on animals by 2023. The resolution calls Member States "to use their diplomatic networks and act with determination in every possible bilateral and multilateral negotiating forum to build a strong and broad coalition in support of a global ban on animal testing in the cosmetics sector" ${ }^{41}$ Since 2009 , finished cosmetic products and cosmetics ingredients tested on animals have been forbidden in the EU market. ${ }^{42}$ However, animal testing for cosmetics is common practice in $80 \%$ of countries of the world, ${ }^{43}$ and in some countries, like China ${ }^{44}$, it is even a mandatory requirement for the commercialization of imported products. The existence of a strict regulation on animal testing for cosmetics in Europe, although it has improved the standards and encouraged alternative methods, has not been effective because many ingredients have been tested on animals

\footnotetext{
${ }^{34}$ According to the Dispute Settlement Body (DSB) of the WTO, animal welfare can justify a restriction on trade because it concerns public morality. See WTO Appellate Body Report, European Communities - Measures Prohibiting the Importation and Marketing of Seal Products, WTO Doc. WT/DS400/AB/R and WT/DS401/AB/R (adopted June 18, 2014) [EC - Seal Products, AB Report]. See also SYKES, K., Globalization and the Animal Turn: How International Trade Law Contributes to Global Norms of Animal Protection. Transnational Environmental Law, 5(1) (2016), 55-79. DOI: https://doi.org/10.1017/S2047102516000054.

${ }^{35}$ See OIE, supra note 5 .

${ }^{36} \mathrm{FAO}$ and WHO collaborate in the definition of the guidelines of the Codex Alimentarius which takes into consideration principles of animal welfare in animal feeding for livestock.

${ }^{37}$ About the role of states as fundamental subjects of international law and the crisis of this traditional model, see DOMINGO, R., The New Global Law (Cambridge 2010).

${ }^{38}$ Ibid., at 59, 66 and 109. Domingo recognizes the emergence of new global actors in the international scene that are social agents and makers of the "nonstate law"; this "indispensable pluralism of a global society clashes with the nation-state's pretense of exclusivity". About the role of IOs see ALVAREZ, supra note 17, at 1. For a general overview on non-state actors in international law, see KLABBERS, supra note 17, at 90-97. See also DARIAN-SMITH, E., Law and Societies in Global Contexts: Contemporary Approaches (New York 2013).

39 ALVAREZ, supra note 17, at 218.

${ }^{40}$ About the cultural perception of animals and values of animal protection see SYKES, K., 'Nations Like Unto Yourselves': An Inquiry into the Status of a General Principle of International Law on Animal Welfare. 49 Canadian Yearbook of International Law, (2011), 3-49, p.35. DOI: https://doi.org/10.1017/S0069005800010316; KELCH, T. G., Towards Universal Principles for Global Animal Advocacy. Transnational Environmental Law, 5(1) (2016), 81-111, p.83. DOI: https://doi.org/10.1017/S2047102515000308.

${ }^{41}$ European Parliament Resolution of 3 May 2018 on a Global Ban to End Animal Testing for Cosmetics (2017/2922(RSP)).

${ }^{42}$ EUROPEAN PARLIAMENT, Why MEPs Want a Global Ban on Animal Testing for Cosmetics (2018, February 21). Webpage: http://www.europarl.europa.eu/news/en/headlines/society/20180216STO98005/why-meps-want-a-global-ban-on-animal-testing-forcosmetics [Retrieved May 20, 2019].

43 EUROPEAN PARLIAMENT, Testing Cosmetics on Animals: MEPs Call for Worldwide Ban (2018, May 3). Webpage: http:/www.europarl.europa.eu/news/en/press-room/20180426IPR02613/testing-cosmetics-on-animals-meps-call-for-worldwide-ban [Retrieved May 20, 2019].

${ }^{44}$ TAYLOR, K., REGO ALVAREZ, L., Regulatory Drivers in the Last 20 Years Towards the Use of in Silico Techniques as Replacements to Animal Testing for Cosmetic-Related Substances, Computational Toxicology, 13 (2020), 100112, p. 1. DOI: https://doi.org/10.1016/j.comtox.2019.100112.
}

68 Derecho Animal. Forum of Animal Law Studies, vol. 11/2 
outside the EU and then re-tested in the EU using alternative methods ${ }^{45}$ Although animal testing for scientific research is still allowed in Europe ${ }^{46}$ the 2018 resolution recognizes the public demand for an overall ban of animal testing. ${ }^{47}$ This example demonstrates that, in order to guarantee effectiveness of domestic regulation, the global dimension of animal protection has to be properly considered, otherwise local or regional advanced regulations protecting animals are compromised. The call of the European Parliament for a diplomatic effort to build a coalition for a global ban, albeit in its form of nonbinding resolution, demonstrates that European authorities are aware of the impasse ${ }^{48}$ of animal protection in the globalised society and that they are committed to find a global solution.

Inspired by the EU Parliament resolution, in November 2018, three NGOs - Organizzazione Internazionale Protezione Animali (OIPA), ${ }^{49}$ Association Suisse pour l'Abolition de la Vivisection (ATRA) ${ }^{50}$ and Ligue Suisse Contre la Vivisection (LSCV) ${ }^{51}$ - proposed the creation of a UN agency dedicated to animals. OIPA has suggested that this organization should provide a solid strategy for the development of animal protection by promoting the adoption of regulations protecting animals, establishing an information desk that could address issues concerning animal law presented by member states, and providing information to NGOs and actors involved in animal protection. ${ }^{52}$ The creation of an international organization for animal protection is an ambitious project that could have an important impact on the definition of global policies in favour of animals, and, in the long run, on the consideration of animals as subjects of law and rights holders in international law. A better definition of the goals, institutional form, members, components, and mechanisms of functioning of this institution is necessary.

\section{Existing reference models}

At the moment, there is no international model organization that could provide an adequate single reference template to be adopted as it is for the proposed organization on animal protection. Various options will be evaluated to look for possible models and existing mechanisms of functioning that can be adapted and used in designing the organization on animal protection. In this section three different institutions will be presented and analysed: the EU Platform on Animal Welfare, UNEP, and UNFF. The EU Animal Welfare Platform has significant thematic affinity with the proposed global organization on animal protection. The analysis dedicated to the EU Animal Welfare Platform will focus on the organization of the work of the Platform around relevant animal protection themes. The model of UNEP is interesting because of the ongoing debate about its status and the proposal to upgrade UNEP to a specialized agency. The case of UNEP is useful to ponder the advantages and disadvantages of different types of organization: programme $v s$ specialized agency. UNFF represents a unicum in the UN system. At present, a clear proposal or project has not been defined by the three NGOs that promoted the idea of a UN agency on animal protection. However, during informal discussions, the model of UNFF has been taken into consideration by OIPA as a possible model for the future organization. While the first three subchapters are descriptive, in the last part of this section points of strength and weakness of the three reference models will be assessed considering the needs of animal protection.

\subsection{European Union Animal Welfare Platform}

Given the rise of public concern for animal welfare ${ }^{53}$ and protection, Europe has witnessed the

\footnotetext{
45 European Parliament resolution of 3 May 2018, supra note 41.

46 The central legal document in this respect is Directive 2010/63 of the European Parliament and of the Council of 22 September 2010 on the protection of animals used for scientific purposes, OJ L 276, 20.10.2010, 33-79. Paragraph 10 of the preamble affirms that "the use of live animals continues to be necessary to protect human and animal health and the environment. However, this Directive represents an important step towards achieving the final goal of full replacement of procedures on live animals for scientific and educational purposes as soon as it is scientifically possible to do so".

${ }^{47}$ European Parliament resolution of 3 May 2018, supra note 41.

${ }^{48}$ BLATTNER, supra note 8 , at 52-54.

${ }^{49}$ OIPA, "L’ONU Apra agli Animali": le Associazioni Animaliste Riunite Presso la Sede delle Nazioni Unite a Ginevra Chiedono l'Apertura di un' Agenzia ONU per i Diritti Animali (2018, November 14). Webpage: https://www.oipa.org/italia/conferenza-ginevra/ [Retrieved April 16, 2020].

${ }^{50}$ ATRA, Une Agence de l'ONU Pour les Droits des Animaux. Webpage: https://www.atra.info/index.php/fr/396-une-agence-de-1onu-pour-les-droits-des-animaux [Retrieved June 16, 2019].

${ }^{51}$ FOURNIER, L., Une Agence pour Défendre les Droits des Animaux à l'ONU, Nullius in Verba LSCV, 62 (2018, December), p. 3.

52 OIPA, supra note 49.

53. According to the results of the Special Eurobarometer 442, an "absolute majority of Europeans (94\%) are of the view it is important to protect the welfare of farmed animals. More than half of respondents (57\%) consider it to be "very important" and 37\% to be "somewhat important" to protect the welfare of farmed animals. Only a very small proportion (4\%) of respondents do not consider the welfare of farmed animals to be important". The conclusions of the survey show that "animal welfare is a very important issue
} 
establishment of specific policies and governance apparatus on this topic. The EU Platform on Animal Welfare was established in 2017 by the EU Commission ${ }^{54}$ in the framework of the animal welfare policy and as part of the EU Animal Welfare Strategy 2016-2020, which has been supported by the European Parliament ${ }^{55}$ and the European Council. ${ }^{56}$

The purpose of the Commission was to create a multi-stakeholder group of experts that could provide assistance to the Commission on issues related to animal welfare. ${ }^{57}$ The competences of the Platform are extended also to broader matters such as health, trade, food safety, scientific research, and environment when they deal with aspects that concern animal welfare. With the purpose of enhancing dialogue among stakeholders and in order to deal with such a multiplicity of topics, the commission has guaranteed that different types of actors with specialised expertise can participate in the Platform. The Platform counts 75 members ${ }^{58}$ which include representatives of all Member States of the EU plus Norway, Iceland, and Liechtenstein as parties of the European Economic Area (EEA), business organizations that operate with food animal products and farming, civil society organizations, independent experts, representatives of academic and research institutes working on animal welfare as protectors of the public interests, IOs such as OIE, FAO, the World Bank, ${ }^{59}$ and the European Food Safety Authority (EFSA). The members of the Platform have been selected with the aim of representing different sectors and interests. Through their dialogue, they exchange knowledge and information on policies, new standards, scientific innovations, guidelines, and best practices that can contribute to a better enforcement and understanding of existing EU legislation on animal welfare. ${ }^{60}$ The Platform should also facilitate businesses' voluntary commitments to animal welfare ${ }^{61}$ and promote EU animal welfare standards at global level. ${ }^{62}$

Since the scope and the field of work of the Platform are quite broad, technical subgroups have been created by the Director-General for Health and Food Safety in order to focus on more specific priorities in a very practical and concrete approach. ${ }^{63}$ In 2017, the subgroup on animal transport ${ }^{64}$ was established, followed in 2018 by a subgroup on welfare of pigs. ${ }^{65}$ Other workgroups on horses, cats and dogs, farmed fish, and pullets have been created on voluntary initiative of some of the Platform's Members. ${ }^{66}$ Meetings of the Platform are scheduled at least twice a year and at the request of the EU Commission. While performing their activities, the members should also invite and take into consideration the work of external forums ${ }^{67}$ and networks on animal welfare, for example the European Food Safety Authority (EFSA) network or the OIE Regional Platform on Animal Welfare for Europe. ${ }^{68}$

for Europeans" and that it deserves better protection. EUROPEAN COMMISSION, Special Eurobarometer 442: Attitudes of Europeans Towards Animal Welfare, (2016, March), p. 4, 9 and 60

${ }^{54}$ Commission Decision of 24 January 2017 Establishing the Commission Expert Group 'Platform on Animal Welfare' (Text with EEA relevance), C/2017/0280, OJ C 31, 31.1.2017, 61-66.

${ }^{55}$ European Parliament Resolution of 26 November 2015 on a New Animal Welfare Strategy for 2016-2020 (2015/2957(RSP)), OJ C $366,27.10 .2017,149-150$.

${ }^{56}$ COUNCIL OF THE EUROPEAN UNION, Outcome of The Council Meeting, 3464th Council meeting Agriculture and Fisheries. Brussels, (2016, 17 May), p. 5-6.

${ }^{57}$ Commission Decision, supra note 54, at Preamble para. (8) p. 61. For a definition of animal welfare see OIE, supra note 7.

${ }^{58}$ Ibid. Commission Decision, at art. 4 p. 62-63.

${ }^{59}$ EUROPEAN COMMISSION, Launch of the EU Platform on Animal Welfare: Q\&A on Animal Welfare policy (2017, June 6). Webpage: http://europa.eu/rapid/press-release MEMO-17-1426_en.htm [Retrieved June 15, 2019].

${ }^{60}$ Commission Decision, supra note 54, at art. 2 p. 62 . The mission of the Platform is: "to exchange information, scientific knowledge, and best practices related to animal welfare between Member States and all relevant stakeholders. This forum will promote animal welfare standards internationally and improve the enforcement of existing legislation on animal welfare", see EUROPEAN COMMISSION, Register of the Commission Expert Groups and Other Similar Entities, EU Platform on Animal Welfare. Webpage: https://ec.europa.eu/transparency/regexpert/index.cfm?do=groupDetail.groupDetail\&groupID=3504 [Retrieved April 20, 2020].

${ }^{61}$ Ibid. Commission Decision, at art. 2(b) p. 62

${ }^{62}$ The Platform shall "contribute to the promotion of Union standards on animal welfare as to valorise the market value of Union products at global level". Ibid., at art. 2(c) p. 62.

${ }^{63}$ Ibid., at art. 8 p. 64; regarding the identification of EU priorities in animal welfare, see ANDRIUKAITIS, V., Speech by Commissioner for Health and Food Safety Vytenis Andriukaitis at the European Parliament's Intergroup on the Welfare and Conservation of Animals in Strasbourg, France (2018, December 13). Webpage:

https://ec.europa.eu/commission/commissioners/2014-2019/andriukaitis/announcements/speech-commissioner-health-and-foodsafety-vytenis-andriukaitis-european-parliaments-intergroup_en [Retrieved June 14, 2019].

64 EUROPEAN PLATFORM ON ANIMAL WELFARE, Subgroup on Animal Transport. Webpage: $\mathrm{https://ec.europa.eu/food/animals/welfare/eu-platform-animal-welfare/thematic-sub-groups/animal-transport} \mathrm{en} \mathrm{[Retrieved} \mathrm{June} \mathrm{08,}$ 2019].

${ }^{65}$ EUROPEAN PLATFORM ON ANIMAL WELFARE, Subgroup on Pigs. Webpage: https://ec.europa.eu/food/animals/welfare/euplatform-animal-welfare/thematic-sub-groups/pigs_en [Retrieved June 08, 2019].

${ }^{66}$ ANDRIUKAITIS, supra note 63.

${ }^{67}$ EUROPEAN COMMISSION, supra note 59.

${ }^{68}$ Commission Decision, supra note 54, at preamble para. (9) p. 61.

70 Derecho Animal. Forum of Animal Law Studies, vol. 11/2 


\subsection{United Nations Environment Programme}

The creation of UNEP was decided during the United Nations Conference on the Human Environment held in Stockholm in 1972. ${ }^{69}$ The principal tasks of UNEP are: the promotion of international cooperation and the definition of policies and international instruments on environmental issues, monitoring and evaluating the environmental situation, and coordinating initiative for environmental protection. ${ }^{70}$

UNEP's executive director leads the Senior Management Team composed by the directors of UNEP divisions and heads of regional offices. ${ }^{71}$ UNEP counts eight divisions: science, corporate services, communication, policy and programme, law, governance affairs, ecosystems, economy. ${ }^{72}$ Rather than being organised on the base of key environmental themes, UNEP divisions have been created on the base of their function. As a consequence, a specific environmental issue is not addressed exclusively by one single leading division in charge of formulating a comprehensive policy on that topic; rather, the competence and the organization of the work is divided among several departments each addressing and focusing on a particular aspect of the problem. ${ }^{73}$ In 2012, following the Rio Conference, UNEP was reformed and the original Governing council was replaced by the Environment Assembly based on an universal membership with 193 member states whose representatives meet every two years to define the global environmental agenda. ${ }^{74}$ Representatives of IOs with an interest in the field of environment can take part in Environment Assembly meetings without the right to vote. ${ }^{75}$ Decisions of the Environment Assembly are taken by majority of the present members. ${ }^{76}$ Accredited NGOs are granted observer status. Upon invitation of the president and approval of the Assembly, NGOs' representatives can make oral statements. ${ }^{77}$ The involvement of civil society within UNEP is regulated through the Global Major Groups and Stakeholders Forum, which gathers representatives of nine major groups of civil society organizations and stakeholders: farmers, women, the scientific and technological community, children and youth, indigenous peoples and their communities, workers and trade unions, business and industry, non-governmental organizations, and local authorities. The Global Major Groups and Stakeholders Forum acts as a platform where civil society representatives are informed about UNEP policies, exchange opinions, and create synergies and common views to be presented to the Environment Assembly. ${ }^{78}$ Inter-sessional works of the Assembly are managed by the Committee of Permanent Representatives, formed by 118 members which provide advice and support in the preparation of the Assembly's agenda, contribute to the development of policies and draft decisions that will be submitted for adoption to the Environment Assembly. ${ }^{79}$ Every two years the Committee of Permanent Representatives

\footnotetext{
${ }^{69}$ Following the Stockholm declaration, the UN General Assembly established UNEP by Resolution 2997 of 15 December 1972. UNGA Resolution 2997 (XXVII) Institutional and Financial Arrangements for International Environmental Cooperation, UN Doc. A/RES/2997(XXVII) (15 December 1972), preamble.

${ }^{70}$ Ibid.; see also UNEP, What We Do. Webpage: https://www.unenvironment.org/about-un-environment/what-we-do [Retrieved July 4, 2019].

${ }^{71}$ UNEP, Structure and Leadership. Webpage: https://www.unenvironment.org/about-un-environment/why-does-un-environmentmatter/structure-and-leadership [Retrieved July 4, 2019].

72 UNEP, UN Environment Divisions. Webpage: https://www.unenvironment.org/about-un-environment/why-does-un-environmentmatter/un-environment-divisions [Retrieved August 1, 2019].

${ }^{73}$ This organizational structure has caused fragmentation and inefficiencies, as it has been stated in 1997 by the Report of the SecretaryGeneral on the activities of the Office of Internal Oversight Services which reviewed UNEP: "The functional responsibilities of various major departments are not entirely clear, and there seems to be no clear delegation of authority. The internal instruments for collective guidance are cumbersome, dilute responsibility and impede efficiency. Furthermore, there is no coherent and comprehensive presentation in the programme budget of the global involvement of UNEP in environmental matters. Oversight of implementation and assessment of results is fragmented, making it hard to develop clear and coherent policies for the allocation of resources or to ascertain that resources are being utilized efficiently". See UN, Review of the United Nations Environment Programme and the Administrative Practices of Its Secretariat, Including the United Nations Office in Nairobi (UNON). Report of the Secretary-General on the activities of the Office of Internal Oversight Services. (A/51/810) (1997), p. 3. Ivanova has noted that "UNEP does not have divisions on Water, Air, Climate Change, or Biodiversity. Rather, the divisions are organized in a functional chain - early warning and assessment, policy development and law, policy implementation, etc. The organizational structure across functional lines has resulted in many overlapping mandates and has scattered issue expertise across the organization. It has led to excessive competition among divisions and between UNEP and other institutions taking UNEP away from its comparative strengths and putting unnecessary burden on its human and financial capacity". See IVANOVA, M., Assessing UNEP as Anchor Institution for the Global Environment: Lessons for the UNEO Debate, Yale Center for Environmental Law \& Policy, Working Paper No. 05/01, (2005), p.18.

${ }^{74}$ UNEP, UN Environment Assembly and Governing Council. Webpage: http://web.unep.org/environmentassembly/un-environmentassembly-and-governing-council [Retrieved July 8, 2019].

${ }^{75}$ UNEP, Rules of Procedure of The United Nations Environment Assembly of The United Nations Environment Programme. Webpage: https://www.unenvironment.org/cpr/environment-assembly-rules-procedure [Retrieved May 4, 2019], rule 69 p. 16.

${ }^{76}$ Ibid., at rule 49 p. 13.

${ }^{77}$ Ibid., at rule 70 p. 17.

${ }^{78}$ UNEP, Why Civil Society Matters. Webpage: https://www.unenvironment.org/civil-society-engagement/why-civil-society-matters [Retrieved August 20, 2019].
}

${ }^{79}$ UNEP, supra note 74 . 
elects five members of the Bureau, the governing body of the Committee. The work of the Environment Assembly and the Committee of Permanent Representatives is regulated through the Rules of Procedure of the United Nations Environment Assembly of UNEP. According to this document, at each session, committees can be created by the Environment Assembly to address specific questions, and if requested subcommittees and subgroups can also be established. ${ }^{80}$ The assembly may set up permanent or ad hoc subsidiary organs and expert groups to report on specific themes and make recommendations. ${ }^{81}$

UNEP is funded through voluntary contributions of member states. To manage the donations the Environment Fund has been created. Since 2002, the Voluntary Indicative Scale of Contributions (VISC) has defined the amount of contribution of each state on the basis of its economic and social circumstances. This tool aims to increase and encourage voluntary contribution by taking into account criteria of fairness. ${ }^{82}$

UNEP is involved in the development of international environmental law and hosts the secretariat of several Multilateral Environmental Agreements (MEAs). ${ }^{83}$ Among these, the Convention on Biological Diversity (CBD), ${ }^{84}$ the Convention on International Trade in Endangered Species of Wild Fauna and Flora (CITES), ${ }^{85}$ and the Convention on the Conservation of Migratory Species of Wild Animals (CMS ${ }^{86}$ deal with species conservation, therefore they are also relevant for animal protection. Beside the further development of environmental law, UNEP, through its Division of Environmental Law and Conventions (DELC), creates synergies among MEAs and supervises a coherent implementation of these conventions. ${ }^{87}$ The cooperation between UNEP and MEAs secretariats aims to provide "programmatic and technical advisory support to MEA Secretariats in the operation and implementation of these agreements". ${ }^{88}$ DELC should also enhance dialogue and cooperation among MEAs by promoting participation in international environmental fora and Conferences and Meetings of the Parties (COP/MOPs) ${ }^{89}$ UNEP faces some obstacles in performing the role of coordination among MEAs mainly for two reasons. Firstly, UNEP is not entitled to any formal authority over MEAs. ${ }^{90}$ Secondly, the UNEP secretariat located in Nairobi is physically distant from MEAs' secretariats. ${ }^{91}$ The location of the secretariat is not of secondary importance because it is related to the different cultural perception of UNEP. Since its creation in the postcolonial historical context of 1972, UNEP has been perceived as a western institution opposed to the interests of developing countries. ${ }^{92} \mathrm{UNEP}$ is one of the few international institutions based in a developing country. This logistic choice has been criticized because it keeps UNEP away from the main political centres of Geneva and New York.${ }^{93}$ However, given the conflicting perception of UNEP, Nairobi as UNEP headquarters assumes a symbolic significance.

UNEP contributes to the creation of environmental knowledge and to the assessment of the global environmental situation. ${ }^{94}$ The acquisition of scientific and technical information is functional to the elaboration of policies and the definition of priorities for international cooperation. ${ }^{95}$ UNEP analyses and reviews the data collected by various institutions, NGOs, and universities around the world and publishes

\footnotetext{
${ }^{80}$ UNEP, supra note 75 at rule 61 p. 15 .

${ }^{81}$ Ibid., at rule 63 p. 15.

${ }^{82}$ UNEP, Environment Fund. Webpage: https://www.unenvironment.org/about-un-environment/funding/funding-facts/environmentfund [Retrieved July 8, 2019].

${ }^{83}$ UNEP, Links to UNEP MEA Secretariats. Webpage: http://web.unep.org/divisions/delc/resources/links-unep-mea-secretariats [Retrieved August 9, 2019].

${ }^{84} \mathrm{CBD}$, supra note 4.

${ }^{85}$ CITES, supra note 4.

${ }^{86} \mathrm{CMS}$, supra note 4.

${ }^{87}$ UNEP, UNEP Signs Agreement to Improve Monitoring of Hundreds of International Environmental Accords, 09 September 2013. Webpage: https://www.unenvironment.org/news-and-stories/press-release/unep-signs-agreement-improve-monitoring-hundredsinternational [Retrieved May 4, 2020].

${ }^{88}$ UNEP, MEAs Support and Cooperation. Webpage:

http://web.unep.org/divisions/delc/our-work/env-governance-conventions/meas-support-and-cooperation [Retrieved August 9, 2019]. ${ }^{89}$ Ibid.

${ }^{90}$ IVANOVA, M., Can the Anchor Hold? Rethinking the United Nations Environment Programme for the 21st Century. Forestry \& Environmental Studies Publications Series, 27 (2005).

${ }^{91}$ Ibid.

${ }^{92}$ See NAJAM, A., Developing Countries and Global Environmental Governance: From Contestation to Participation to Engagement. International Environmental Agreements: Politics, Law and Economics, 5(3) (2005), 303-321. DOI: https://doi.org/10.1007/s10784005-3807-6.

${ }^{93}$ IVANOVA, supra note 90, at 38. See also NAJAM, A., PAPA, M., TAIYAB, N., Global Environmental Governance: A Reform Agenda (Winnipeg 2006) 39-40.

94 UNGA, supra note 69.

95 Nairobi Declaration on the Role and Mandate of UNEP (UNEP/Gc19/1/1997). Adopted during the Nineteenth Session of the Governing Council.

Webpage: https://wedocs.unep.org/bitstream/handle/20.500.11822/17274/97_GC19 proceedings.pdf?sequence=23\&isAllowed=y [Retrieved
} August 19, 2019].

72 Derecho Animal. Forum of Animal Law Studies, vol. 11/2 
assessment reports in the Global Environmental Outlook (GEO). ${ }^{96}$ This collecting and reviewing process has provided a fundamental contribution to the spread of environmental knowledge and awareness especially among policy makers, academics, and scientists, but also in the general public. ${ }^{97}$ GEO has also been adopted as a methodology of reporting by governments that have shaped their national environmental reports on the GEO model. ${ }^{98}$

UNEP works within the framework of the 2030 Agenda for Sustainable Development, ${ }^{99}$ and has developed the Environmental, Social and Economic Sustainability (ESES) Framework a policy tool for evaluating projects, policies, and activities performed by UNEP or its partners. ${ }^{100}$ It is based on two fundamental principles and nine Safeguards Standards. The two approaches that apply to all projects where UNEP is directly or indirectly involved ${ }^{101}$ are: the science-based precautionary approach, and the human rights-based approach. The Safeguard Standards are concrete requirements that UNEP has to implement in its projects and activities. They concern nine thematic areas:

1. Biodiversity conservation, natural habitats, and sustainable management of living resources;

2. Resource efficiency, pollution prevention and management of chemicals and wastes;

3. Safety of dams;

4. Involuntary resettlement;

5. Indigenous peoples;

6. Labor and working conditions;

7. Protection of tangible cultural heritage;

8. Gender equality;

9. Economic sustainability.

UNEP was established to fulfil ambitious goals with a quite wide mandate, however the financial and structural resources it was provided with were inadequate and insufficient. ${ }^{102}$ To address organizational and functional difficulties, an ongoing debate on possible solutions has advanced the idea to upgrade UNEP to a United Nations Environmental Organization (UNEO) with the status of specialized agency. In 2003, the French president Jaques Chirac launched the proposal of UNEO. ${ }^{103} \mathrm{UN}$ programmes are created under Art. 22 of the UN Charter. UN programmes are not autonomous organizations, they are subsidiary bodies of the UN General Assembly, do not have full legal personality, and depend on voluntary funding. UN specialized agencies, by contrast, are established under arts. 57 and 63 of the UN Charter, they benefit from an autonomous status, legal personality, and higher and more stable budget than UN programmes. ${ }^{104}$ The problem of guaranteeing stronger funding was one of the main issues raised in favour of the transformation of UNEP into a specialized agency. ${ }^{105}$ The financial mechanism based on voluntary contributions has kept UNEP highly dependent on states interests and political will, ${ }^{106}$ allowing states to impose their own priorities. ${ }^{107}$ Consequently, the authority and independence of UNEP have been questioned. ${ }^{108}$ In the view of supporters of the UNEO proposal, better funding would improve the effectiveness of UNEP work, it would also allow it to enlarge its staff, guarantee more autonomy, and eventually help the accomplishment of its mandate. Opposing arguments suggest that a new organization with the status of a specialized agency would not solve these

\footnotetext{
${ }^{96}$ IVANOVA, supra note 90 , at 16.

${ }^{97}$ Ibid.

${ }^{98}$ Ibid.

${ }^{99}$ UNEP, Environmental, Social and Economic Sustainability Framework. Webpage: https://www.unenvironment.org/about-unenvironment/why-does-un-environment-matter/environmental-social-and-economic [Retrieved July 8, 2019].

${ }^{103}$ CHIRAC, J., Discours de M. Jacques Chirac, Président de la République, sur la Coopération Franco-Britannique sur la Lutte Contre le Changement Climatique, le Développement Durable et la Protection de la Biodiversité (2003, November 24). Webpage: http://discours.vie-publique.fr/notices/037000360.html [Retrieved August 21, 2019].

${ }^{104}$ OLSEN, S. H., \& ELDER, M., Strengthening International Environmental Governance by Two-Phased Reform of UNEP: Analysis of Benefits and Drawbacks, (2011). Webpage: https://www.files.ethz.ch/isn/143825/ieg_policy_report_s_olsen.pdf [Retrieved August 19, 2019].

${ }^{105}$ MEYER-OHLENDORF, N., KNIGGE, M., A United Nations Environment Organization. In L. S. PERRY, Global Environmental Governance - Perspectives on the Current Debate (New York 2007) 125.

${ }^{106}$ IVANOVA, supra note 90 , at 34 .

${ }^{107}$ Ibid.

${ }^{108}$ Ibid., at 35
} 
problems, ${ }^{109}$ because the real root cause is the states' unwillingness to "provide UNEP with the resources that would be required to do what they claim it ought to do". ${ }^{110}$ According to this view, the creation of an environmental agency is a purely formal cosmetic upgrade that would not guarantee substantial resources to $\mathrm{UNEP} / \mathrm{UNEO}$ to address environmental problems and fulfil its mandate; on the contrary, expanding the organizational structure of the organization would probably generate more costs, adding financial and bureaucratic burden. UNEO would also improve UNEP's role as global environmental governance coordinator. According to some scholars, the creation of other competing international institutions operating in the field of environment ${ }^{111}$ has marginalized UNEP and has made clear its weakness and impossibility to keep the leadership. ${ }^{112}$ UNEO would dispose of enhanced functions and authority that would allow it to take the leadership of the international environmental governance. ${ }^{113}$ UNEO would rationalize the existing MEAs by strengthening coherence and coordination in order to avoid institutional fragmentation and overlapping areas. ${ }^{114}$ However, the upgrade to a specialized agency status would not automatically resolve the problem of coherence of the various MEAs and it is not in itself a guarantee of enhanced capacity of coordination.

In 1972, the option of establishing an environmental agency was excluded ${ }^{115}$ because other existing UN specialized agencies were already dealing with environmental issues at that time, ${ }^{116}$ and if a new specialized agency had been created, competences and environmental authority should have been transferred to the new agency. This handover had been judged complicated and as a possible cause of jurisdictional disputes. ${ }^{117}$ Moreover, a specialized agency was not synonymous with efficiency and good performance; on the contrary, the apparatus of a specialized agency entails a consolidated hierarchical structure with complex bureaucratic procedures. ${ }^{118}$ The coordinating function of UNEP necessitated high flexibility and the ability to quickly respond to external inputs, and these requirements did not fit with the inflexible mechanisms and the bureaucracy of a specialized agency. ${ }^{119}$ Also, the parties chose the programme status for UNEP because the establishment of a specialized agency would have required a complex and long negotiation among states for the definition of the funding treaty. ${ }^{120}$ These arguments are still valid today and have been considered in the recent debate about UNEO. While the proposal to upgrade UNEP is still on the table and has gained growing support, ${ }^{121}$ the focus of the debate has become broader, including more general considerations about the substantial strengthening of the global environmental governance. ${ }^{122}$

\subsection{United Nations Forum on Forests}

UNFF was established in October 2000 by the United Nations Economic and Social Council (ECOSOC) resolution 2000/35. This resolution was the result of a process that started in 1992 with the United Nations Conference on Environment and Development of Rio de Janeiro. On this occasion, the Authoritative Statement of Principles for a Global Consensus on the Management, Conservation and Sustainable Development of All Types of Forests and the Agenda 21 were adopted. ${ }^{123}$ To implement the principles adopted in the Rio conference, the UN established in 1995 the Intergovernmental Panel on Forests (IPF) and in 1997 the Intergovernmental Forum on Forests (IFF). ${ }^{124}$ IPF and IFF were working groups reporting to the

\footnotetext{
${ }^{109}$ YOUNG, O. R., The Architecture of Global Environmental Governance: Bringing Science to Bear on Policy. Global Environmental Politics, 8(1) (2008), 14-32, p. 17-20. DOI: https://doi.org/10.1162/glep.2008.8.1.14.

${ }^{110}$ NAJAM, A., The Case Against a New International Environmental Organization. Global Governance, 9(3) (2003), 367-384, p. 372. DOI: https://doi.org/10.1163/19426720-00903008.

${ }^{111}$ In the 1990s, the Commission on Sustainable Development and the Global Environment Facility were established with an environmental protection mandate. At the same time the World Bank began to focus its work on environment related themes.

112 IVANOVA, supra note 90 , at 22.

${ }^{113}$ BIERMANN, F., Reforming Global Environmental Governance. From UNEP Towards a World Environment Organization. In L. SWART, \& E. PERRY, Global Environmental Governance. Perspectives on the Current Debate (2007), Political Science, Multilayered Governance in Europe and Beyond (MLG) 105-106.

${ }^{114}$ KHOR, M., Global Governance and the Environment. In J. DATOR, D. PRATT, \& Y. SEO, Fairness, Globalization, and Public Institutions: East Asia and Beyond (Honolulu 2006) 163.

115 IVANOVA, M., Institutional Design and UNEP Reform: Historical Insights on Form, Function and Financing. International Affairs, 88(3) (2012), 565-584, p. 576. DOI: https://doi.org/10.1111/j.1468-2346.2012.01089.x.

116 Ibid., at 576-577. At that time, the Man and Biosphere programme of the United Nations Educational Scientific and Cultural Organization (UNESCO), the WHO work on health and environment, and the FAO Codex Alimentarius exercised functions in the environmental field.

${ }^{117}$ Ibid., at 577.

${ }^{118}$ Ibid.

${ }^{119}$ Ibid.

120 Ibid.

${ }^{121}$ Ibid., at 569.

122 YOUNG, supra note 109.

${ }^{123}$ UNFF, UN Forum on Forests. Webpage: https://www.un.org/esa/forests/forum/index.html [Retrieved June 25, 2019].

${ }^{124}$ HUMPHREYS, D., The Creation of the United Nations Forum on Forests. Environmental Politics, 10 (2001), 160-166, p. 160. 
Commission on Sustainable Development (CSD), whose proposals led to the creation of UNFF as a subsidiary body of ECOSOC. UNFF's mandate is to promote "the conservation, management and sustainable development of all types of forests and to strengthen long-term political commitment to this end". ${ }^{125}$ Its functions are: ${ }^{126}$

a) To provide a coherent, open, transparent and participatory global platform for policy development, dialogue, cooperation and coordination on issues related to all types of forests, including emerging issues, in an integrated and holistic manner, including through cross-sectoral approaches;

b) To promote, monitor and assess the implementation of sustainable forest management, in particular the non-legally binding instrument on all types of forests and the achievement of its global objectives on forests, and mobilize, catalyse and facilitate access to financial, technical and scientific resources to this end;

c) To promote governance frameworks and enabling conditions at all levels to achieve sustainable forest management;

d) To promote coherent and collaborative international policy development on issues related to all types of forests;

e) To strengthen high-level political engagement, with the participation of major groups and other stakeholders, in support of sustainable forest management.

Membership is based on universal participation, which means that all UN member states and specialized agencies are members of UNFF. UNFF reports directly to ECOSOC. ${ }^{127}$ UNFF represents an unique case in the UN system; as no other ECOSOC subsidiary body has a membership larger than ECOSOC itself. ${ }^{128}$ Since 2007, UNFF members meet every two years and decisions are taken by consensus. ${ }^{129}$ The structure of UNFF's work is based on multi-year programs of work which consist in the description of activities that UNFF will perform in the framework of the Rio Declaration on Environment and Development, Agenda 21, and the IFF/IPF proposals including financial provisions. ${ }^{130}$ UNFF also develops strategic plans for forests, the most recent one being the strategic plan for forests 2017-2030. At the end of each UNFF session, the Bureau chairperson and its four vices are elected, they are responsible for the follow up ${ }^{131}$ of decisions made at UNFF sessions, and for the preparation of future sessions. ${ }^{132}$ Further, the Bureau chairperson represents the UNFF in various fora. The administrative and logistic work is carried out by the UNFF secretariat based in New York. The Secretariat works in coordination with the secretariat of the $\operatorname{CSD}^{133}$ and serves also the Collaborative Partnership on Forests (CPF). UNFF has close collaboration with the CSD and respects the UN Sustainable Development Framework. ${ }^{134}$ UNFF can establish ad hoc expert groups that should provide advices on technical and financial issues. ${ }^{135}$ In the initial intentions of the ECOSOC resolution 2000/35, UNFF should have recommended "parameters of a mandate for developing a legal framework on all types of forests". ${ }^{136}$ In this regard, in 2007 UNFF adopted the Non-legally Binding Instrument on All Types of Forests ${ }^{137}$ and the four Global Objectives on Forests. ${ }^{138}$ In 2015, a working group was established to develop proposals for the replacement of the reference to the Millennium Development Goals in the Non-Legally Binding Instrument on all Types of Forests with a framework that refers to the new UN Sustainable

DOI: https://doi.org/10.1080/714000519.

${ }^{125} \mathrm{UNFF}$, supra note 123.

${ }^{126}$ ECOSOC Resolution 2015/33 International arrangement on forests beyond 2015, UN Doc. E/RES/2015/33 (22 July 2015), art. 3.

${ }^{127}$ HUMPHREYS, D., The United Nations Forum on Forests: Anatomy of a Stalled International Process. Global Environmental Change, 13 (2003), 319-323, p. 320. DOI: https://doi.org/10.1016/S0959-3780(03)00008-6.

${ }^{128}$ ECOSOC counts 54 members states elected every three years on the basis of regional representation criteria; see ECOSOC, FAQWhere Can I Find the Current Membership?. Webpage: https://www.un.org/ecosoc/en/FAQ\#currentmember [Retrieved August 23, 2019]. About UNFF universal membership, see HUMPHREYS, D., Logjam: Deforestation and the Crisis of Global Governance (New York 2006) 88.

${ }^{129}$ MAGUIRE, R., Global Forest Governance: Legal Concepts and Policy Trends (Cheltenham 2013) 100.

${ }^{130}$ See HUMPHREYS, supra note 127.

${ }^{131}$ It is not clear whether "follow up" means actively implementing or monitoring the development of the decisions.

132 UNFF, Forum Bureau. Webpage: https://www.un.org/esa/forests/forum/bureau/index.html [Retrieved June 10, 2019].

${ }^{133}$ ECOSOC Resolution 2000/35 Report on the fourth session of the Intergovernmental Forum on Forests, UN Doc. E/RES/2000/35 (18 October 2000), para. 10

${ }^{134}$ Ibid., at para. 4(h).

${ }^{135}$ UNFF, Ad-hoc Expert Groups. Webpage: https://www.un.org/esa/forests/forum/aheg/index.html [Retrieved April 25, 2020].

${ }^{136}$ ECOSOC, supra note 133, at para. 3 (c) (i).

${ }^{137}$ UNGA Resolution 62/98 Non-legally binding instrument on all types of forests, UN Doc. A/RES/62/98 (17 December 2007).

138 UNFF, Global Objectives on Forests. Webpage: https://www.un.org/esa/forests/documents/global-objectives/index.html [Retrieved April 25, 2020]. 
Development Goals (SDGs). ${ }^{139}$ As in the case of UNEP, the involvement of civil society stakeholders in UNFF is organized through nine Major Groups defined in Agenda 21. The Major Groups can participate in the multi-stakeholder dialogue by developing proposals to contribute to the work of UNFF. ${ }^{140}$ Through their focal points, ${ }^{141}$ they submit to the Secretariat inputs about issues that will be discussed in the UNFF sessions. ${ }^{142}$ The cooperation with other organizations is regulated through the CPF, which is composed of 15 institutions with a focus on forests, including, among others: FAO, Secretariat of CITES, UNEP, World Bank, the Global Environment Facility, and the World Conservation Union. ${ }^{143}$

\subsection{Assessment of the three reference models}

The multidisciplinary tasks and plurality of actors that characterise the EU Platform on Animal Welfare are common features with the foreseen institution on animal protection. Both institutions share the need to bring different kinds of stakeholders to work together. The EU Platform provides an excellent model for this purpose ${ }^{144}$ because its members represent a plurality of actors and interests. In particular, the fact that private business, States, NGOs, and the academic experts are all equal parts of the same institution is a fundamental feature that can guarantee effective and concrete results. Since IOs, such as the OIE, the World Bank, and FAO, are also members of the EU Platform, the dialogue between the EU Commission and these organizations is integrated in the constitutive structure of the Platform. This model of participation can be imitated in the future global institution to facilitate synergies and cooperation. Membership and involvement might be modulated according to different needs, in order to enable a more open participation. The thematic subgroups can be useful to organize the work of the future global organization on animal protection in order to deal with specific issues with a more oriented strategy. According to the initial OIPA proposal, the future organization will have an executive function performing concrete activities such as the creation of information desks and the active promotion of international initiatives on animal protection. ${ }^{145}$ The model of the EU Platform does not fully respond to these needs because it has a consultative function on request of the EU Commission. Therefore, other models need to be considered concerning the implementation of activities.

UNEP deals with the complexity of environment protection and has a very wide mandate. This model is therefore useful to address the complexity of animal protection and its wide scope. The structure of UNEP divisions can be copied to create ad hoc units for each thematic component of animal protection. The functional criteria of UNEP divisions has been widely criticized since it creates overlapping mandates and fragmentation of expertise with consequent inefficiency and waste of resources. ${ }^{146}$ Due to the functional criteria, the UNEP divisions do not have exclusive competences on specific environmental themes, and this constitutes an obstacle to the development of coherent and coordinated policies. This aspect should be taken into account in the organization on animal protection, and a thematic criteria should be preferred for the creation of the internal divisions. Collateral functional divisions devoted, for example, to legal affairs, communication and external relation, financial division etc., could be established to support the work of the thematic divisions. Both UNEP and UNFF's governing body concedes universal membership for UN member states. The membership criteria are of primary importance in the proposed organization on animal protection. The concept of universal membership should be further investigated and re-interpreted to include non-state actors. A mechanism of participation in the plenary sessions that grants more than a mere observer status should be evaluated and might take a cue from the model of major groups of UNEP and UNFF. Another of UNEP and UNFF's features to pay attention to is the mechanism of voting decisions by consensus or majority. On one hand, consensus guarantees an effective negotiation and subsequent acceptance of the outcomes; ${ }^{147}$ on the other hand, it risks slowing down the decision making process and impeding progress and necessary changes. In a unanimity/consensus regime, every member state has potentially a veto right, ${ }^{148}$ which might be used as a powerful political tool to settle individual questions not necessarily related to the protection of

\footnotetext{
139 UNFF, UNFF Working Group and Special Session, Webpage: https://www.un.org/esa/forests/forum/2017-working-group-andspecial-session/index.html [Retrieved April 25, 2020].

${ }_{140}$ UNFF, Major Groups Workplan. Webpage: https://www.un.org/esa/forests/major-groups/major-groups-workplan/index.html [Retrieved June 25, 2019].

${ }^{141}$ A focal point is a representative of a major group, each group has a focal point.

${ }^{142}$ UNFF, Multi-Stakeholder Dialogue. Webpage:

https://www.un.org/esa/forests/major-groups/multi-stakeholder-dialogue/index.html [Retrieved June 25, 2019].

${ }_{143}$ CPF, About the Collaborative Partnership on Forests. Webpage: http://www.cpfweb.org/73947/en/ [Retrieved June 26, 2019].

${ }^{144}$ ANDRIUKAITIS, supra note 63.

145 OIPA, supra note 49.

${ }^{146} \mathrm{UN}$, supra note 73 , at 3 .

147 KLABBERS, J., An Introduction to International Organizations Law (Cambridge 2015), 176-177. In decisions adopted by consensus members simply do not express formal objections.

${ }^{148}$ Ibid.

76 Derecho Animal. Forum of Animal Law Studies, vol. 11/2
} 
animals.

An important activity of the organization could be the diffusion of knowledge about animal protection and the assessment of the situation in various regions of the world. The UNEP experience with GEO could be a model for consolidating a network of universities, research institutions, NGOs, experts, and national authorities that could provide data and information about animal protection issues in various countries. This information would help the organization in defining priorities and goals for its policies.

The ESES framework could be adequately adapted to animal protection. Especially, the standards related to biodiversity conservation, natural habitat, sustainable use of land, resources efficiency and pollution prevention (for example in the livestock sector), economic sustainability, and food security will be particularly relevant for the definition of a sustainability framework for the activities related to animal protection. On the basis of safeguard standards, a framework for linking animal protection to SDGs should be created in the new organization. Another lesson that should be taken from UNEP is the importance of different cultural perceptions in the consideration of animals. The fact that there is no consensus on the consideration of animals and their legal status should not be underestimated in the process of the creation of the new institution.

Given the cultural barriers in the perception of animals as holders of fundamental interests that deserve to be protected, and the probable opposition from interest groups, it could be useful for the future organization on animal protection to foresee bridging institutions that can pave the way and facilitate the establishment of the future organization on animal protection, as IPF and IFF did in the case of UNFF. However, the replication of this type of institution might face important difficulties due to the uniqueness of UNFF's institutional form. Many states, EU states in particular, were reluctant to accept the creation of a subsidiary body of ECOSOC with universal membership. ${ }^{149}$ This choice has been considered a "regrettable precedent" by the EU which obtained that resolution 2000/35 explicitly declares that UNFF does not constitute a precedent for the creation of similar institutions. ${ }^{150}$ Given this background, the attempt to replicate the process of establishment of the UNFF might face difficulties and diplomatic obstacles.

\section{A Global institution for animal protection}

The possible constitutive elements of the future institution and the foreseen goals and mandate are outlined in this section. An attempt to design the structure of the proposed organization will be made by describing the main bodies of the organization and drafting their potential duties, functions, and powers. Different membership criteria will also be assessed, and possible dispute settlement mechanisms will be presented. In the context of the developing international animal governance, the interests of animals could find representation in international relations through a public institution capable of interacting as a peer with other IOs. This organization might contribute in strengthening the current animal protection legal and political framework by providing a forum for states to conclude new treaties and strengthen the domestic legislation and policies, promulgating soft law instruments, and providing new criteria and standards for interpreting existing law. In the forthcoming analysis, many unsettled debates over the current development of international law in globalized society will emerge (e.g. the international status of non-state actors such as NGOs and TNCs, the changing role of states and sovereignty in globalized society, and the debate about extraterritorial jurisdiction). It goes beyond the aim of this work to clarify or directly address these unresolved issues. Nevertheless, they might need further consideration during future steps towards the creation of the proposed institution, since they strongly influence the context where the project of this institution will be developed.

\subsection{Goals and mandate}

OIPA has described the ultimate goal of this institution as the will to overcome the hygienic-health emergency approach to animal related issues by shaping a more general and solid strategy of development of animal protection. ${ }^{151}$ The proposal of creating an institution for animal protection is conceived as a strategy to address the need for a global approach to animal protection. In that perspective, the proposed organization should assume the role of leading institution in animal protection governance. It should provide a legal and political framework of reference for the coordination of different actors operating in the field of animal protection and promote animal advocacy in all levels of governance. This institution should operate internationally as an independent centre of power ${ }^{152}$ in juxtaposition with states and other IOs. As leader

\footnotetext{
${ }^{149}$ HUMPHREYS, supra note 127 , at 320 .

150 Ibid.

${ }^{151}$ OIPA, supra note 49 .

${ }^{152}$ About IOs as independent actors in international relations see TREVES, T., Diritto Internazionale, Problemi Fondamentali (Milano
} 
institution in animal protection, the organization would take the responsibility to inform the international community, it would raise awareness about the animal condition, and should work with other OIs for the solution of the main global problems concerning animal protection. It should act as an authoritative focal point capable to catalyse resources and efforts oriented to the fulfilment of its goals. This role of leading institution recalls the UNEP mandate as coordinating institution for the global environmental governance. In 1972, the institutional design of UNEP was shaped in order to guarantee the flexibility required to perform a coordinating role. ${ }^{153} 30$ years later, the UNEO proposal was intended to strengthen UNEP authority and its leadership role. A consolidated institution such as a UN specialised agency presents advantages and disadvantages. On one hand, it can count on a stable budget, a solid authority, and a relative autonomy of action; on the other hand, the bureaucracy and financial burden of its structure constitute important obstacles to its performances. Moreover, the possibility that states show interest and find an agreement on a constitutive treaty for such an institution is remote. ${ }^{154}$ In the definition of the institutional form it has to be considered that the structure and mechanisms of functioning of the proposed organization will have to be designed in order to pursue its goals, ensure a global outreach, and address the complexity of animal protection. That means that a light structure, such as a programme or a forum, will be overburdened and unable to meet the complex features of the topic. A limited membership would probably not guarantee the achievement of global solutions. A weak authority and a fragile independence would impede the realisation of its activities. It is not possible to indicate now the final institutional form of the future organization on animal protection. In this very preliminary phase, we can only look at the previous experience of UNEP in the definition of the possible organizational structure and be aware that particular attention should be given to the balance among authority, leadership capacity, global outreach, universal membership, complexity, bureaucracy, financial costs, flexibility, and adaptability.

Taking into consideration the general description provided by OIPA, ${ }^{155}$ and integrating it in more detailed and extensive discourse about the goals and functions of the proposed organization, the main tasks that this organization should perform are:

- Monitoring and acquisition of knowledge: periodically assessing the current situation in the various fields of animal protection to provide reports to national authorities and partners. This assessment will require the collection of data, acquisition of knowledge and exchange of information with other IOs, member states and partners, and the promotion of scientific research in animal related matters. Following the UNEP example with GEO, the proposed organization could build a network of universities, research centres, NGOs, and local authorities.

- Defining an animal protection agenda: the organization should set an agenda for priorities of intervention in animal protection, advancing standards and policies, and coordinating the actions of other IOs dealing with animals. Similarly to the UNEP Environment Assembly, which defines the environmental agenda, the plenary body of the proposed organization should fulfil this task.

- Law making: the organization should elaborate international norms and promote the adoption of regulations protecting animals at domestic level. Effective multilateral negotiations and dialogue among all actors will guarantee the definition and implementation of global agreements, guidelines, and standards-setting on animal protection. As in the case of the EU Platform, the involvement of all actors in the decision making process should facilitate actors' voluntary commitment. The future institution could refer to the models of UNFF legal framework on forests management and UNEP initiatives for the further development of environmental law.

- Institutional capacity: the organization, in partnership with other IOs, should encourage institutional initiatives at international level and develop institutional capacity by publishing information, enhancing scientific knowledge to spread a culture of respect towards animals, promoting educational and training programmes, and activating services providing information about policies and animal law provisions in the various legal systems. ${ }^{156}$

- Support to member states: the organization should provide technical assistance to member states to achieve the required standards of protection, and implement projects on specific aspects of animal protection in collaboration with national authorities.

2005), p 137; ALVAREZ, supra note 17, at 15-16.

153 IVANOVA, supra note 115 , at 577 .

${ }^{154}$ BLATTNER, supra note 8, at 55. Blattner uses an economic analysis to approach this question.

155 OIPA, supra note 49.

${ }^{156}$ Ibid.

78 Derecho Animal. Forum of Animal Law Studies, vol. 11/2 


\subsection{Structure}

The structure of the new institution will influence the mechanisms of interaction among its members and will determine its autonomy. ${ }^{157}$ The new organization should be created through a diplomatic conference and a negotiation process. At the base of the institution lies, therefore, the community of the constitutive member states represented in the plenary governing body, ${ }^{158}$ which is entitled to take decisions for its members. The UNEP and UNFF plenary bodies granted universal membership to states. The proposed organization on animal protection should ensure the widest possible participation and, besides representatives of all member states, IOs, accredited NGOs, and business actors should be involved in its plenary sessions and in the decision making process. Following the model of the tripartite structure of the International Labour Organization (ILO), ${ }^{159}$ where governments' representatives are flanked by workers and employers delegates, the plenary body of the animal protection organization could be organized in three groups of actors: member states, NGOs as representatives of animals' fundamental interests, and business actors' spokespersons. Whether the delegates of the non-governmental groups should enjoy equal individual voting rights is an issue that deserves deeper analysis and that will be further discussed in the following section about membership. The plenary body elects the secretary general, approves the budget of the organization, elects the members of the permanent board, and appoints experts for the creation of a specialized committee in charge of reviewing the compliance reports. ${ }^{160}$

While the plenary bodies of IOs normally meet only once a year or biannually, the permanent board is a smaller executive body that guarantees a continuous supervision upon the implementation of the plenary body's decisions. ${ }^{161}$ In the proposed organization on animal protection, the members of the permanent board are elected by the plenary body not only, as in the case of UNFF Bureau, respecting an equitable geographical representation, but they should also represent the three main components: states, NGOs, and business actors. The elected members have a temporary mandate ${ }^{162}$ and the period of time they remain in office should be defined during the negotiation process for the creation of the proposed institution. A chairperson elected by the members should direct the meetings. The permanent board is in charge of coordinating and supervising the activities of the divisions, ensuring the implementation of the decisions and performing duties delegated by the plenary body ${ }^{163}$ In particular, the permanent board might create ad hoc working groups in accordance with the decisions and priorities approved by the plenary body.

An independent secretariat could provide administrative services and logistic support. ${ }^{164}$ It could also constitute the contact point with other IOs and coordinate the activities with them. The establishment of a secretariat is important to highlight the autonomy of the organization from its members. ${ }^{165}$ Among its duties there might be the definition of transparent and independent accreditation criteria for NGOs. The personnel policy should be developed in a way that facilitates staff's commitment towards the institution rather than to the interest of any particular state. ${ }^{166}$ The secretary general might have a crucial political role ${ }^{167}$ representing the organization in external fora and advancing animal protection and its principles.

Unlike UNEP, the internal organization of the institution's activities should rely on technical thematic

\footnotetext{
${ }^{157}$ About the autonomy of organizations see PETERS, A., Membership in the Global Constitutional Community. In J. KLABBERS, A. PETERS, \& G. ULFSTEIN, The Constitutionalization of International Law (New York 2010) 208. Peters defines IOs autonomy as "the originality and non-derivability of the organization's law, its 'autonomous' basis of validity". Autonomy could also refer to the non-interference of member states in the definition of the organization's policies, about the policy autonomy see LALL, R., Beyond Institutional Design: Explaining the Performance of International Organizations. International Organization, 71(02) (2017), 245-280, p. 254-255 DOI:10.1017/s0020818317000066.

158 TREVES, supra note 152 , at 146 .

159 The ILO plenary body constitutes a unique case where the delegates of the assembly represent governments, employers, and employees. The employers' and employees' representatives are chosen by the member state upon agreement with the national organizations of the two categories. Both governmental and non-governmental delegates have the right to vote. See ILO, Tripartite Constituents. Webpage: http://www.ilo.org/global/about-the-ilo/who-we-are/tripartite-constituents/lang--en/index.htm [Retrieved July 28, 2019]. See also KLABBERS, supra note 147, at 209; MARTENS, K., Examining the (Non-)Status of NGOs in International Law, Indiana Journal of Global Legal Studies, 10 (2003), 1-24, p.13, DOI: https://doi.org/10.2979/gls.2003.10.2.1; REBASTI, E., Beyond Consultative Status: Which Legal Framework for an Enhanced Interaction between NGOs and Intergovernmental Organizations?. In NGOs in International Law: Efficiency in Flexibility? (Cheltenham 2008) 48.

${ }^{160}$ About the general duties of IOs' bodies, see TREVES, supra note 152, at 146-149.

${ }^{161}$ Ibid., at 147; ALVAREZ, supra note 17, at 9.

${ }^{162}$ A temporary mandate guarantees a rotation among the members of the organization. See SCHERMERS \& BLOKKER, supra note 17 , at 225 .

163 TREVES, supra note 152 , at 147.

${ }^{164}$ KLABBERS, supra note 147 , at 211.

165 ALVAREZ, supra note 17 , at 7.

${ }^{166}$ KLABBERS, supra note 147 , at 244-245.

${ }^{167}$ Klabbers suggests that the "good leader is not merely a faceless bureaucrat, but also, to some extent, a visionary, able to spot the political opportunities and able to adapt the organization to changing times and circumstances". Ibid., at. 259.
} 
divisions. The divisions might focus on the following areas: animal welfare and health, species conservation, habitat conservation, use of animals in research, agriculture and food production, legal personality of animals and animal rights, economy and trade. In each division could work both technical and policy experts. The technical divisions would be supported by functional offices for crosscutting issues such as communication, legal, finance, and ethics, ${ }^{168}$ etc. Within the divisions, technical subgroups on the model of the EU Animal Welfare Platform might be created according to the priorities defined in the political agenda.

As demonstrated by the UNEP case, the funding system is of primary relevance for guaranteeing the autonomy of the new institution. ${ }^{169}$ Also, criteria of transparency should be considered. Regardless of the final institutional form of the organization, it could be envisaged as a system where member states could participate with established financial quota ${ }^{170}$ and eventually provide supplementary contribution in specific projects to cover the additional operational costs. ${ }^{171}$ The contribution of business actors might partially provide financial support on ad hoc initiatives with adequate supervision and transparency mechanisms that should mitigate risks and prevent abuses. ${ }^{172}$ Donations from private companies are a reality for many organizations. ${ }^{173}$ It is important to be aware that the economic support of business actors to specific projects could be used as a tool to inappropriately influence the political agenda. ${ }^{174}$ It would also risk promoting only those projects that correspond to the interests of industry, rather than to real priorities of animal protection. The private funding might steer the outcome of the projects and undermine the autonomy of the organization and its capacity to find and develop adequate solutions to animal protection problems. Therefore, private funding should be limited, transparent, and kept strictly under surveillance in order to avoid a conflict of interests and to protect the independence of the organization.

At national level, the member states could appoint a National Contact Point (NCP) in charge of promoting compliance with the organization's guidelines. ${ }^{175}$ NCPs should organize activities and provide support to companies and national authorities in implementing guidelines. They should also respond to companies' enquires and act as a first entity of conciliation for the resolution of issues that might impede the observance of the guidelines provisions. NCPs should submit an annual report to the organization secretariat with the description of the activities organized to promote the adherence to the guidelines and problems encountered.

\subsection{Members and partners 4.3.1 Universality}

This institution should facilitate the dialogue among stakeholders and bring together different interests. Typically, the founding treaty defines which actors could become members of an organization, as well as the requirements and procedures for membership. ${ }^{176}$ Since this institution aims to have a global reach, universal participation would constitute the best criteria of membership. ${ }^{177}$ In the traditional ius inter nationes, universality refers to the community of states ${ }^{178}$ and to the requisite of statehood ${ }^{179}$ with its criteria of permanent population, defined territory, government, and capacity to enter in relation with other states. For the purpose of this work, the fundamental question that should be asked is whether states alone could provide adequate representation of all interests related to animal protection in the best and most comprehensive way. Given the intrinsically global nature of this matter and the contemporary international socio-legal situation, the answer to this question is necessarily partially negative. New forms of participation should be explored in

\footnotetext{
${ }^{168}$ For an example of Ethic Office see UNDP, Ethics @ UNDP. Webpage: https://www.undp.org/content/undp/en/home/accountability/ethics.html [Retrieved July 10, 2019].

${ }^{169}$ KLABBERS, supra note 147, at 125. KLABBERS has noted that often states use voluntary contribution to gain political influence through the control of the money they donate eroding the autonomy of the organization. About IOs' policy autonomy see LALL, supra note 157.

${ }^{170}$ The membership status of states usually implies the obligation to pay a contribution to the organization to cover the administrative costs. See KLABBERS, supra note 147, at 113.

${ }^{171}$ SCHERMERS \& BLOKKER, supra note 17, at 674-675.

172 Private funding risks undermining the public and democratic character of IOs by making them "contractors for bilateral or publicprivate projects". SEITZ, K., MARTENS, J., Philanthrolateralism: Private Funding and Corporate Influence in the United Nations, Global Policy, 8 (2017), 46-50. DOI: https://doi.org/10.1111/1758-5899.12448.

${ }^{173}$ Ibid., at 46-48; KLABBERS, supra note 147, at 124.

${ }^{174}$ Ibid., SEITZ \& MARTENS, at 49.

175 The model of NCP has been developed by the Organisation for Economic Co-operation and Development (OECD) in the context of its guidelines for multinational enterprises. OECD, National Contact Points. Webpage: http://mneguidelines.oecd.org/ncps/ [Retrieved August 10, 2019].

${ }^{176}$ KLABBERS, supra note 147 , at 90 .

177 Ibid., at 24.

178 ALVAREZ, supra note 29, at 148

${ }^{179}$ Ibid.

80 Derecho Animal. Forum of Animal Law Studies, vol. 11/2
} 
order to give equal representation to the plurality of players involved in animal protection; the concept of universal participation should be extended to non-state actors such as NGOs, IOs, and business organizations. Many scholars have argued that the nation-state centered approach, based on the sacredness of sovereignty and territoriality, is no longer suitable to respond to the current needs of a global society. ${ }^{180}$ On the basis of the ILO tripartism, ${ }^{181}$ NGOs and private business representatives should be officially recognized as participants in the decision making process. According to this model, public and private actors work together to negotiate regulations and to find shared solutions to global problems. This form of collaboration and participation would better represent the contemporary reality and would give voice to the different interests at stake in animal protection, with the final goal to enhance the effectiveness of the organization. Civil society organizations are active on the international scene and have an essential complementary role to states. ${ }^{182}$ Although NGOs and TNCs have been acknowledged as de facto international players, a corresponding formal legal status has not been officially recognized. ${ }^{183}$ In many fields, NGOs have given a very important contribution to the development and updating of standards and international norms. ${ }^{184}$ They usually have a consultative or observer status in IOs without the right to vote in the plenary body. ${ }^{185}$ Business actors' contribution would be frustrated by a mere consultative status since they would not be able to provide their concrete inputs without a proper status of active participants, as in the case of the EU Platform on Animal Welfare. As for NGOs and for business actors, the terms of participation and membership in the governing body of the future organization should be balanced and carefully regulated.

Globalization has called for a transformation of international law ${ }^{186}$ and international society towards a global community, a global civil society, and a corresponding global law. ${ }^{187}$ Domingo defines the global community as a "community of persons and groups, political organizations, municipalities and metropolises, people and nations, corporations, civil associations, churches and other religious organizations, and of course, supranational institutions". ${ }^{188}$ Global civil society "is composed of all those agents who, sharing common interests and universal values, contribute apart from state action to humanity's development by resolving problems that have acquired a global dimension. [...] Global civil society rules by means of a so-called global governance, the fruit of consensus among its social and economic actors based on an implicit social contract". ${ }^{189}$ As it has been stated in the introduction, animal protection has a peculiar global dimension that reflects the structure described by Domingo. The universal inclusion of non-state actors in the proposed organization on animal protection will contribute to the definition of a new global community. However, the problem of legitimacy of NGOs and the risks related to the economic interests of business actors cannot be denied or avoided. In order to deal with these issues, the involvement and the membership of the various participants should be modulated to mitigate these critical aspects. Moreover, since the full membership status and the right to vote of non-state actors would represent an important change in international law, the potential problems and consequences of this option have to be carefully considered.

The participation of different types of actors should in the end respect the independence ${ }^{190}$ of the future organization. The several interests represented in its constitutive bodies should be well balanced and internal procedures should be transparent in order to avoid bias, politicization, prevailing of economic interests and to guarantee neutrality and effectiveness. ${ }^{191}$ Independence will allow the organization to be proactive in the definition of the political agenda ${ }^{192}$ and to undertake autonomous initiative to enhance animal protection.

\footnotetext{
${ }^{180}$ DARIAN-SMITH, supra note 38 , at 7; DOMINGO, supra note 37 , at 53.

${ }^{181}$ See ILO, supra note 159; MARTENS, supra note 159, at 13; KLABBERS, supra note 147, at 209.

182 REBASTI, supra note 159, p. 25 -26. The author states: "not only have NGOs become even more important operational partners in the implementation of IGOs programmes and projects but they have also proves to be able to shape rather than observe the intergovernmental decision-making process in a growing number of fields. NGOs have started playing a crucial role in setting the international agenda, in influencing international rulemaking and in contributing to the implementation of international norms". The dynamic described by Rebasti corresponds to what NGOs have done in the field of animal protection.

${ }^{183}$ MARTENS, supra note 159 , at 2 .

${ }^{184}$ Ibid. at 6; REBASTI supra note 159 , at 25.

185 KLABBERS, supra note 147 , at 98 .

${ }^{186}$ DOMINGO, supra note 37 , at 99 .

187 Ibid., at 102.

188 Ibid.

189 Ibid.

${ }^{190}$ ABBOTT, K. W., SNIDAL, D., Why States Act through Formal International Organizations. The Journal of Conflict Resolution, 42(1) (1998, February), 3-32, p. 16. DOI: https://doi.org/10.1177/0022002798042001001.

${ }^{191}$ According to Abbott and Snidal "IOs facilitate interstate collaboration by pushing negotiations forward. This role could be played by, say, a dominant state, but suspicions of bias might impede cooperation, an independent IO may be more acceptable because it is neutral". Ibid., at 17.

${ }^{192}$ Ibid.
} 


\subsubsection{States}

States have the power to establish IOs specialized in matters where the need for a structured cooperation with other states is perceived. ${ }^{193}$ IOs are normally established by international multilateral agreements negotiated by states, which define the competences and the range of autonomy within which an organization can operate. In other words, IOs can act only with the consent of, and within the limits established by states. ${ }^{194}$ States are the primary participants of IOs and usually they are the only members entitled with the right to vote. Consequently, they maintain a strict control over the decision making process. Even though the globalization process has challenged states' sovereignty and territoriality ${ }^{195}$ the current norms remain the traditional ones regulating an international community dominated by national sovereignities where the decision power in OIs is an exclusive prerogative of states. ${ }^{196}$ The proposed organization on animal protection will make no exception. It will need a multilateral negotiation among states that, through a convention or a UN resolution, will constitute the organization. The diplomatic process that will lead to the promulgation of the founding text of the new institution will be crucial. Why should states come together to establish such an institution? Why should they cooperate on animal protection? It is not within the possible scope of this work to provide a comprehensive analysis of the several theories of international relations applied to the creation of an international institution on animal protection. Only two among the major approaches will be considered: realism and constructivism. ${ }^{197}$ From a realistic perspective, ${ }^{198}$ states might engage themselves in the negotiation, if they envisage benefits higher than costs with the possibility to pursue their own interests. ${ }^{199}$ According to the realistic logic, through the proposed organization, states with high domestic standards of animal protection could motivate other states to enhance their own standards in order to stop the dumping effect of lower standards. In this way, states might find in the new institution a partner for reinforcing the effectiveness of national animal protection norms. ${ }^{200}$ States that host endangered species on their territories might benefit from participation in this institution because it would improve cooperation on species conservation and against illegal trade and hunting. The constructivist perspective considers collective meanings, shared values and socially constructed interests of states. ${ }^{201}$ According to this theory, states engage in the creation of an international institution only when "they share a basic perception of the problem". ${ }^{202}$ Constructivism recognizes the importance of non-state actors, civil society, and epistemic communities (transnational communities of experts) ${ }^{203}$ in shaping and promoting the adherence of states and international actors to collective meanings and values. ${ }^{204}$ This emphasizes the autonomous development of international organizations $\mathrm{s}^{205}$ as agents capable of influencing their own members and the entire international community. ${ }^{206}$ The proposed institution would encourage the circulation of information, ideas, and practices about the protection of animal rights and interests, and would eventually enhance state capacity in managing animal protection. Through this organization states would be able to perform collective actions that only a

\footnotetext{
193 TREVES, supra note 152, at 129. Schermers and Blokker argue that the creation of IOs "is the result of the need felt by states to cooperate within an institutional framework. This need arises because states no longer consider themselves capable of performing a given task independently"; the existence of IOs is therefore "entirely instrumental, directly related to the performance of certain functions". SCHERMERS \& BLOKKER, supra note 17, p.18.

${ }^{194}$ Ibid. TREVES, at 116.

${ }^{195}$ DOMINGO, supra note 37 , at 65-76.

196 TREVES, supra note 152 at 31-32.

197 These two theoretical approaches are the most relevant to the type of organization proposed here. As Abbott and Snidal state: "The creation and development of IOs often represent deliberate decisions by states to change their mutually constituted environment and, thus, themselves. IOs can affect the interests and values of states in ways that cannot be fully anticipated. Yet, it is important to stress that these processes are initiated and shaped by states. Furthermore, IOs are constrained by institutional procedures-including financial contributions leadership appointments-that are controlled by states and, ultimately, by the ability of (some) states to withdraw, albeit at some cost. These possibilities and limitations make IOs an important window into the relation between rationalist and constructivist analysis". ABBOTT, \& SNIDAL, supra note 190, at 26-27. For further analysis on international relations theoretical approaches see KLABBERS, supra note 147.

198 Ibid. KLABBERS, at 28.

${ }^{199}$ ABBOTT, \& SNIDAL, supra note 190, at 8.

${ }^{200}$ Alvarez notes a tension between IOs independence and their role as states' agents reinforcing national governance and "making national efforts more effective". ALVAREZ, supra note 17, at 262.

${ }^{201}$ HURD I., Constructivism. In C. REUS-SMITH, D. SNIDAL, The Oxford Handbook of International Relations (Oxford 2009$) 302$. DOI: https://doi.org/10.1093/oxfordhb/9780199219322.003.0017.

${ }^{202}$ RITTBERGER, V., ZANGL, B., KRUCK, A., DIJKSTRA, H., International Organization (London 2019$) 24$.

${ }^{203}$ HAAS, P. M., Introduction: Epistemic Communities and International Policy Coordination, International Organization, vol. 46, no. 1 (1992), 1-35. DOI: https://doi.org/10.1017/S0020818300001442.

${ }^{204}$ RITTBERGER, V., ZANGL, B., KRUCK, A., DIJKSTRA, H, supra note 202, at 24.

${ }^{205}$ ABBOTT, \& SNIDAL, supra note 190, at 8; KLABBERS, supra note 147, at 31-32

${ }^{206}$ RITTBERGER, V., ZANGL, B., KRUCK, A., DIJKSTRA, H, supra note 202, at 24-25.

82 Derecho Animal. Forum of Animal Law Studies, vol. 11/2
} 
multilateral agent such as an international organization can carry out. ${ }^{207}$ An example of collective action in animal protection is the call of the European Parliament for a global ban of cosmetic tests on animals. ${ }^{208} \mathrm{An}$ older example is the creation in 1924 of OIE. States agreed on the creation of this institution because they recognized the need for international cooperation in addressing zoonosis, a problem that could have not been solved by single states alone. A collective organization also constitutes an advantage in terms of efficiency in the use of resources, integrated efforts, and results. These benefits might mitigate the financial costs and the bureaucratic burden of this institution. The primary motivation for states to establish this organization is the need to cooperate on the issue of animal protection, and for this purpose they have to create a shared platform with a stable functional structure that allows the implementation of various activities.

\subsubsection{NGOs}

NGOs have contributed substantially to the evolution of animal protection. Through publications and communication campaigns documenting for example the brutal conditions of transportation of live animals and the abuses in agriculture and in research, NGOs raise awareness and influence public opinion. Through advocacy and lobbying, they manage to influence the political process and ameliorate standards and laws at domestic and international level. Many NGOs have the capacity to strongly advocate in favour of animals, mobilize resources, and influence the public debate. There are many examples of communication campaigns shaping public opinion and legal actions in favour of animals, ${ }^{209}$ vegan societies promoting a cruelty free and sustainable way of living, and NGOs in Europe lobbying at EU institutions. ${ }^{210}$ They encourage a public discourse on animal protection and a cultural change in the perception of animals that will be reflected in the law. ${ }^{211}$ NGOs can also be partners of public authorities in law enforcement, as demonstrated by the actions of Sea Shepherd in the case of the Thunder, an outlaw fishing vessel wanted by Interpol that was sunk and its crew arrested thanks to a Sea Shepherd operation against illegal poaching. ${ }^{212}$ Through these activities NGOs have acquired considerable experience and specialized knowledge in the various branches of animal protection that could be useful in the proposed global institution. While the majority of states do not fully acknowledge animals as subjects of law with legitimate interests, animal protection NGOs are the only actors that recognize and represent animals interests. NGOs are therefore major experts in animal protection and genuinely act as representatives of animals, having their best interests at heart. Consequently, in an IO focused on animal protection, the possibility should be given to NGOs to participate and positively use their experience.

The model provided by the EU Animal Welfare Platform could be taken into consideration for defining the parameters of NGOs selection and participation in the proposed organization. The selection criteria could also refer to the requisites for NGOs consultative status with ECOSOC, or association with the Department of Public Information (DPI) ${ }^{213}$ There are three different categories of accreditation for consultative status by ECOSOC: general, special, and rooster. ${ }^{214}$ The general consultative status is granted to NGOs that perform activities concerning most of the domain of interest of ECOSOC and therefore they are expected to contribute substantially to the realization of UN goals. ${ }^{215}$ NGOs specialized in few domains of activity of ECOSOC are granted the special consultative status. ${ }^{216}$ The rooster list includes NGOs that can provide occasional

\footnotetext{
${ }^{207}$ ABBOTT, \& SNIDAL, supra note 190, at 12.

${ }^{208}$ Only a multilateral entity such as the European Parliament could have the chance to propose this kind of initiative. A single state alone would not have the means and the diplomatic strength to achieve the results that only through a concerted action could be realized.

${ }^{209}$ An example among many is the case of the orca Tilikum. The People for the Ethical Treatment of Animals (PETA) sued SeaWorld for keeping Tilikum in a state of slavery. The court decision affirmed that the Thirteen Amendment of US Constitution applies only to humans. See United States District Court, S.D. California, Tilikum v. SeaWorld Parks \& Ent., Inc., 842 F. Supp. 2 d 1259 (S.D.Cal 2012) (U.S.). See also the work of the Non-human Rights Project, supra note 33.

${ }^{210} \mathrm{An}$ example is the work of the Eurogroup for Animals, which advocates at EU level to improve animal protection. See Eurogroup for Animals. Webpage: https://www.eurogroupforanimals.org/key-achievements [Retrieved May 8, 2020].

${ }^{211}$ About the importance of public discourse as a driver of democratic change in the law see SANKOFF, P., Canada's Experiment with Industry Self-Regulation in Agriculture: Radical Innovation or Means of Insulation? Canadian Journal of Comparative and Contemporary Law, 5(1) (2019), 299-348, p. 326.

212 Sea Shepherd Operation Icefish News. Webpage: https://www.seashepherdglobal.org/our-campaigns/icefish/latest-news/ [Retrieved July 28, 2019].

${ }^{213}$ UNOG, The United Nations \& Civil Society. Webpage:

https://www.unog.ch/80256EE60057E07D/(httpHomepages)/2E72458FCDA07B16C1257ED700313B19?OpenDocument

[Retrieved July 28, 2019]. About the ECOSOC consultative status see REBASTI, supra note 159. The author explains that the term

"consultative" was intended to explicitly exclude NGOs from the decision making process.

${ }^{214}$ Ibid. REBASTI, at 25.

${ }^{215}$ ECOSOC Resolution 1996/31 NGO related Resolution, UN Doc. E/RES/96/31 (25 July 1996), para. 22.

${ }^{216}$ Ibid., para. 23.
} 
contribution. ${ }^{217}$ Given the great variety of NGOs active in animal protection, it would be useful to maintain in the proposed institution a modulated accreditation according to the degree of expertise, size, representativeness, and relevance of the NGOs' activities for the institution. ${ }^{218} \mathrm{~A}$ fundamental point in the involvement of NGOs is the neutrality in the admission procedures. The definition of the criteria for accreditation should not be decided directly by states in order to avoid unwanted interference from national interests. ${ }^{219}$ The secretariat of the organization, which would act as guarantor of the independence of the institution, should be in charge of the definition of transparent and fair accreditation criteria. ${ }^{220}$ The model of Major Groups provided by UNEP and UNFF could be adapted to the context of the institution for animal protection by grouping NGOs in relevant sectors. Some of these sectors could be: animal welfare, research and alternative methods, veterinary and animals health care, species and habitat conservation, agriculture, working animals (including animals used in entertainment), and animal rights. The members of each group should elect their focal points, which will represent the group in the sessions of the plenary body of the organization.

The traditional consultative status or observer role seem insufficient to grasp the potential contribution of NGOs in the international community, ${ }^{221}$ in particular in the field of animal protection. Whether representatives of NGOs should be granted the right to vote remains a controversial question, which would also imply an important change in contemporary international law. ${ }^{222}$ On one hand, NGOs have given a paramount contribution to animal protection, and they might deserve to actively participate in the decision making process of the organization with the right to vote. On the other hand, NGOs are not elected entities, therefore recognizing the right to vote would require addressing the difficulties related to their legitimacy ${ }^{223}$ and accountability. ${ }^{224}$ The fragility of their legitimacy represents a considerable obstacle to the acknowledgement of the right to vote in the organization's governing body, which might also hide some risks, such as the participation of NGOs not fully committed to the protection of animals, for example hunter organizations, breeders, and zoos, etc. In the field of animal protection, NGO legitimacy and accountability are difficult to assess. They rely mainly on the value of NGOs' concrete actions and transparency policies, which make NGOs credible as legitimate representatives of animals' interests. The legitimacy of NGOs is not defined on the basis of democratic, territorial, or citizenship arguments; instead, it is grounded on the transparent and clearly declared representation of specific public concerns and interests, on the commitment in protecting those interests, and on the scale of support they gain in terms of membership. NGOs are a fundamental part of the global dialogue and theoretically they act independently ${ }^{225}$ from economic and political powers. ${ }^{226}$ Also, accreditation by IOs contributes to the legitimacy of NGOs in legal terms. ${ }^{227}$ NGOs are accountable to their members and sponsors, however they lack a stable democratic structure and transparent mechanisms and procedures. ${ }^{228}$ Despite these weaknesses, NGO legal status and capacity to participate in the decision making process of the proposed organization on animal protection should be strengthened by virtue of the fact that NGOs have demonstrated strong commitment in representing animals interests and that they have acquired credibility through their factual contribution to the development of animal protection.

\subsubsection{Economy and business actors}

Economic interests are the "unmoved mover" in contemporary globalized society. They play a pivotal role in the current consideration of animals as property and units of production, ${ }^{229}$ and they influence the

\footnotetext{
217 Ibid., para. 24.

218 PETERS, supra note 157, at 224.

${ }^{219}$ Ibid., at 223.

${ }^{220}$ Ibid.

${ }^{221}$ Ibid., at 221. See also REBASTI, supra note 159 , at 26, 38 and 39.

${ }^{222}$ About the status of NGOs in international law, see KLABBERS, supra note 17, at 96. See also the constitutionalist approach to international community proposed by Peters, PETERS, supra note 157.

${ }^{223}$ Ibid., PETERS, at 235-236. Legitimacy is usually related to the democratic structure of the organization. However, Peters suggests that "NGOs possess legalist legitimacy through their international accreditation. They enjoy moral legitimacy depending on the worthiness and credibility of their aims and mission. Their social legitimacy derived from acceptance is visible in a large membership and broad donorship".

${ }^{224}$ Ibid., at 237. Concerning accountability, Peters states that "NGOs are legally accountable to their 'chartering' governments, and also subject to reputational and financial accountability. [...] Only to a limited extent, NGOs satisfy cross-cutting accountability principles such as transparency, participation, evaluation, and complaint and response".

${ }^{225}$ See MARTENS, supra note 159.

${ }^{226}$ REBASTI, supra note 159 , at 45.

227 PETERS, supra note 162, at 235 -236.

228 Ibid., at 237-238.

${ }^{229}$ Despite a process of de-objectification of animals has begun, it is still a common and accepted belief to associate animals to objects 
development of animal protection. ${ }^{230}$ By addressing the unresolved issues of protection of animals used in agriculture and other economic sectors, ${ }^{231}$ the proposed organization on animal protection could influence the economic development towards a more sustainable model of production. ${ }^{232}$ The involvement of international financial institutions and private business representatives in the future organization should facilitate the transition from a system based on animal exploitation to a new economic paradigm that dismisses the use of animals as profitable resources. It would also contribute to updating the sustainability framework by taking into account animal protection principles in social responsibility policies, private business guidelines, good practices, and certifications. ${ }^{233}$

\section{International financial institutions}

Livestock has been acknowledged having negative consequences for the environment and social justice, ${ }^{234}$ which should be taken into account by international financial institutions in their investment criteria. The business responsibility policies of international financial institutions include provisions about environmental protection, sustainability, and in some cases animal welfare. The International Finance Corporation (IFC) refers to animal welfare as a business opportunity that improves efficiency and profitability by increasing production and quality, and responds to consumers demand and international market requirements. ${ }^{235}$ IFC has developed a "Good Practice Note Improving Animal Welfare in Livestock Operations". ${ }^{236}$ The initial draft was reviewed by NGOs, international institutions and national ministries. ${ }^{237}$ While a general opposition to intensive farming was expressed, the idea of exploitation of animals for food production was challenged only by a minority of the reviewers and only one of them supported animal rights. ${ }^{238}$ The Note recognises animal welfare as a component of sustainable development, ${ }^{239}$ an opportunity, ${ }^{240}$ and a "competitive advantage" 241 for business. The Note is complementary to IFC's

at humans' disposal that can be traded, eaten, worn and used as commodities in many economic sectors. See KELCH, supra note 11, at 23. About the process of de-objectification see GIMÉNEZ- CANDELA, M., The De-objectification of Animals (I). dA Derecho Animal (Forum of Animal Law Studies), vol. 8/2 (2017), 1-4. DOI: https://doi.org/10.5565/rev/da.318; GIMÉNEZ-CANDELA, M., The De-objectification of Animals (II). dA Derecho Animal (Forum of Animal Law Studies), vol. 8/3 (2017), 1-2. DOI: https://doi.org/10.5565/rev/da.250; GIMÉNEZ-CANDELA, M., The De-objectification of Animals in Spanish Civil Code. dA Derecho Animal (Forum of Animal Law Studies) vol. 9/3 (2018), 28-47. DOI: https://doi.org/10.5565/rev/da.361.

${ }^{230}$ The relationship between economy and animal protection is twofold: on one hand, economic interests have been decisive in motivating states to create agreements on species conservation such as CITES and the International Convention for the Regulation of Whaling (ICRW); on the other hand, economy has an important role in limiting animal protection only to some categories of animals, excluding for example livestock animals. CITES and ICRW were originally driven by the need to find a balance between the protection of commercial interests related to the exploitation of specific species and the preservation of an ecological equilibrium that would have guaranteed the existence of the economic activities. In the ICRW, whales are considered as resources and commodities, the conservation of whale stocks is functional to the development of the whaling industry. CITES combines species protection with "sustainable" trade. In this context, the term "sustainable" means that the survival of specimens of the protected species should not be threatened by over-exploitation. See BLATTNER, supra note 10, at 25-26.

${ }^{231}$ Animals used in industrial production of food and other goods constitute the majority of animals that have an interaction with humans, they do not benefit from the same degree of protection as other categories of animals (e.g. pets). Livestock animals are the least protected by the law because they are considered as profitable products to whom applies the dogma of maximisation of productivity and efficiency. For example in the USA livestock animals are excluded from the protection of the Animal Welfare Act, see United States of America, Federal Animal Welfare Act. Webpage: https://www.govinfo.gov/content/pkg/USCODE-2015title7/html/USCODE-2015-title7-chap54.htm [Retrieved October 29, 2019].

232 STEINFELD, supra note 22 , at 4 ; FAO, supra note 23.

${ }^{233}$ BLATTNER, supra note 8 , at 199 .

${ }^{234}$ Livestock contributes for example to small farmers exclusion and poverty, land grabbing, unequal distribution of resources. See NELLEMANN, supra note 23, at 26; FAO, supra note 22, at 3; STEINFELD, supra note 22, at 4-6 and 24; ALEXANDER \& DUDLEY, supra note 29 , at 8 .

${ }_{235}$ IFC, Creating Business Opportunity through Improved Animal Welfare. Webpage: http://documents.worldbank.org/curated/en/494081468177535252/pdf/626320BRI0Crea00Box0361488B0PUBLIC0.pdf [Retrieved August 15, 2019].

${ }^{236}$ IFC, Good Practice Note Improving Animal Welfare in Livestock Operations. Webpage: https://www.ifc.org/wps/wcm/connect/c39e4771-d5ae-441a-9942-

dfa4add8b679/IFC+Good+Practice+Note+Animal+Welfare+2014.pdf?MOD=AJPERES\&CVID=kGxNx5m. [Retrieved August 13, 2019].

237 BOTHA, C. S., Tip Sheet: Key Changes to IFC's 2006 Good Practice Note on Animal Welfare and Summary of Outreach (2014). Webpage: $\quad$ https://www.ifc.org/wps/wcm/connect/62ab36e9-0cb4-4485-975242b279469095/Animal_Welfare_Key_Changes_December_2014_final.pdf?MOD=AJPERES\&CVID=kJhvnjz. [Retrieved August 13, 2019].

${ }^{238}$ RYAN, O., Animal Welfare and Economic Development: A Financial Institution Perspective. In J. D'SILVA, \& J. TURNER, Animals, Ethics and Trade: The Challenge of Animal Sentience (Oxon, 2006) 241.

${ }^{239}$ IFC, supra note 236 , at 21.

${ }^{240}$ RYAN, supra note 238 , at 240 .

${ }^{241}$ IFC, supra note 236 , at 1. 
Performance Standards on Environmental and Social Sustainability, in particular to the chapter on Biodiversity conservation and Sustainable Management of Living Natural Resources. ${ }^{242}$ The World Bank encourages pastoral development and considers livestock as a fundamental sector for vulnerable communities and in sustainable food system. ${ }^{243}$ However, the Bank avoids "funding large-scale commercial grain-fed feedlot systems and industrial milk, pork, and poultry production". ${ }^{244}$ The World Bank sustains "climatesmart" measures ${ }^{245}$ to mitigate the negative livestock environmental impact. The Environmental and Social Policy of the European Bank for Reconstruction and Development (EBRD) excludes the possibility to finance projects that involve forced feeding of ducks and geese and fur production. ${ }^{246}$ EBRD's requirements about the sustainable management of living natural resources refer to EU animal welfare standards in case of farming, transport and slaughtering of animals; ${ }^{247}$ they also address the issue of antimicrobial resistance in accordance with EU environmental standards. ${ }^{248}$ A relevant topic concerning EBRD is the exclusion of financial support to tobacco industry. ${ }^{249}$ The exact reasons of this exclusion are not clarified by EBRD. However, if the motivation is based on health and social concerns, the same reasoning might be applied to livestock and production of meat.

Although the sustainability policies of the international financial institutions incorporate some mitigating measures and animal welfare principles, they do not question the existence of livestock and do not envisage the need to change paradigm in food production and food security. The fact that in many countries livestock sector is heavily subsidized by governments ${ }^{250}$ and international investments constitutes an obstacle to change, it alters the market self-regulating mechanism, externalizes costs, and promotes inefficient use of resources. ${ }^{251}$ Despite the mitigation measures, the funding provided by international financial institutions to livestock sector contributes to this distorting mechanism. The investments of financial institution could be used as incentives to shift the governments' economic focus towards other forms of agriculture avoiding the use of animals. The proposed organization should act as powerful drivers of political and economic change supporting investors and governments in exploring alternative ways to guarantee food security and economic development. In collaboration with international financial institutions, the proposed organization should translate the technical and scientific information about the unsustainable environmental and social impact of livestock, into new sustainability criteria for the allocation of investments consistent with animal protection principles.

\section{Private business}

The involvement of business actors such as TNCs representatives in the future organization might focus on animal welfare private governance standards, and on plant-based business which excludes animals from

\footnotetext{
${ }^{242}$ Ibid.; IFC, Performance Standard 6: Biodiversity Conservation and Sustainable Management of Living Natural Resources. Webpage: https://www.ifc.org/wps/wcm/connect/topics ext_content/ifc_external_corporate_site/sustainability-at-ifc/policiesstandards/performance-standards/ps6 [Retrieved August 15, 2019].

243 WORLD BANK, Moving Towards Sustainability: The Livestock Sector and the World Bank. Webpage: https://www.worldbank.org/en/topic/agriculture/brief/moving-towards-sustainability-the-livestock-sector-and-the-world-bank. [Retrieved August 18, 2019].

${ }^{244}$ DE HAAN, C., VAN VEEN, T. S., BRANDENBURG, B., GAUTHIER, J., LE GALL, F., MEARNS, R., \& SIMEON, M., Livestock Development: Implications for Rural Poverty, the Environment, and Global Food Security (2001), p. 65. Webpage: http://documents.worldbank.org/curated/en/306051468740146162/Livestock-development-implications-for-rural-poverty-theenvironment-and-global-food-security [Retrieved August 7, 2019].

${ }^{245}$ Some of the sustainable "climate-smart" measures are: the use of bio-digesters, reduction of the use of fertilizer, improved conservation of water, better waste management in meat-processing plants, conversion of degraded land into silvo-pastoral systems which generate carbon sequestration and facilitate conservation of biodiversity. WORLD BANK, supra note 243; WORLD BANK, Climate Smart Agriculture. Webpage: https:/www.worldbank.org/en/topic/climate-smart-agriculture [Retrieved August 20, 2019].

${ }^{246}$ EBRD, Environmental and Social Policy, p.13. Webpage: https://www.ebrd.com/news/publications/policies/environmental-andsocial-policy-esp.html [Retrieved August 19, 2019].

${ }^{247}$ Ibid., at 58. Despite the inclusion of animal welfare requirements in EBDR Environmental and Social Policy, the investment decisions of the Bank have raised concerns among animal welfare NGOs. An example is the case of the Ukrainian poultry producer MHP which has applied for $€ 100$ million loan to EBRD for the acquisition of a majority stake in a Slovenian poultry products producer. EBRD, MHP Regional. Webpage: https://www.ebrd.com/work-with-us/projects/psd/mhp-balkans.html [Retrieved August 19, 2019]; SWABE, J., Animal Welfare Deserves Better from Investment Policy. Webpage: https://www.euractiv.com/section/eurofinance/opinion/animal-welfare-deserves-better-from-investment-policy/ [Retrieved August 19, 2019]; ANIMAL WELFARE INTERGROUP, Ending the Investment of International Finance Institutions into Intensive Animal Agriculture Outside the EU. Webpage: https://www.animalwelfareintergroup.eu/2017/02/09/ending-the-investment-of-international-finance-institutions-intointensive-animal-agriculture-outside-the-eu/ [Retrieved August 19, 2019].

${ }^{248}$ EBRD, supra note 246, at 58.

${ }^{249}$ EBRD, Project Finance. Webpage: https://www.ebrd.com/work-with-us/project-finance.htm [Retrieved August 19, 2019].

${ }^{250}$ STEINFELD, supra note 22, at 222.

${ }^{251}$ Ibid., at 223.

86 Derecho Animal. Forum of Animal Law Studies, vol. 11/2
} 
the supply chain and avoids their use as commodities.

Animal welfare represents a quite new component of corporate social responsibility ${ }^{252}$ and has become part of the general category of voluntary quality standards ${ }^{253}$ responding to a specific consumers demand and willingness to afford higher prices. ${ }^{254}$ Animal welfare labels often are Business to Consumers (B2C) ${ }^{255}$ "premium" standards that differentiate the certified products from the "normal" not-certified ones. ${ }^{256}$ Beside B2C standards, "baseline"257 Business to Business standards (B2B) standards provide information among producers, suppliers and retailers (but not to consumers) about the safety and quality of products. B2B standards are defined internationally by large groups of industry stakeholders ${ }^{258}$ and ensure the conformity of the production process to safety and quality requirements and to minimum conditions of market access. Some of them, such as Global Good Agricultural Practices (GlobalG.A.P.), include requirements about animal welfare. ${ }^{259}$ Since baseline standards have an impact on general market access, the issue of their legitimacy becomes relevant. In the case of GlobalG.A.P., Diane Ryland suggests that legitimacy can be acknowledged by consumers, public authorities, and the capacity to find shared solutions to issues of common interest. ${ }^{260}$ These solutions should take into account scientific evidences and consumers moral values. According to Ryland, the legitimacy of GlobalG.A.P. animal welfare standards could be strengthened by establishing a dialogue with public authorities responsible for animal welfare, namely OIE. ${ }^{261}$ The proposed organization on animal protection could also participate in this dialogue to reinforce the commitment of GobalG.A.P. and other B2B standards in favour of animals. ${ }^{262}$ The ultimate aim should be to introduce principles of animal protection into the safety and quality criteria of baseline standards. ${ }^{263}$ The proposed organisation could also supervise the application of self-regulating standards to prevent animal welfare from being used to artificially increase prices with few inconsistent changes in animal husbandry that barely meet the minimum certification requirements. Certifications could be used as profitable marketing tools to improve a brand image. For these reasons animal welfare standards have been widely criticized and tagged as "humane-washing" ${ }^{264}$ marketing initiatives. The main argument against animal welfare standards claims that certifications do not really tackle the problems and do not provide a comprehensive response to the needs for sustainable methods of production, protection of consumers and workers' health and respect of animals. On the contrary they sell a misleading unrealistic animal-friendly propaganda ${ }^{265}$ whose final goal is the preservation of livestock production and the

${ }^{252}$ MORATH, S. J., Private Governance and Animal Welfare, George Washington Journal of Energy and Environmental Law, 9 (2018), 21-32, p. 26.

${ }^{253}$ In the last decades the number of standards in the food sector is tremendously augmented especially in the field of animal welfare. RANSOM, E., The Rise of Agricultural Animal Welfare Standards as Understood through a Neo-Institutional Lens, International Journal of Sociology of Agriculture and Food, 15(3) (2007), 26-44, p. 26. About the definition of best practice to review animal welfare standards see MAIN, D. C., MULLAN, S., ATKINSON, C., COOPER, M., WRATHALL, J. H., \& BLOKHUIS, H. J., Best Practice Framework for Animal Welfare Certification Schemes. Trends in Food Science \& Technology, 37(2) (2014), 127-136. DOI: https://doi.org/10.1016/j.tifs.2014.03.009.

${ }^{254}$ RANSOM, supra note 253 , at 27 . The label that comes with the certification of conformity with a certain standard could be used as a marketing tool and price leverage by the producers.

255 They provide information to final consumers about the special features of the product.

${ }^{256}$ HENSON, S., HUMPHREY, J., Private Standards in Global Agri-food Chains. In A. MARX, M. MAERTENS, \& J. F. SWINNEN, Private Standards and Global Governance Economic, Legal and Political Perspectives (Cheltenham 2012) 101.

257 Ibid., at 102.

258 Ibid., at 99.

${ }^{259}$ GlobalG.A.P. takes into account livestock, transportation, and aquaculture in the Integrated Farm Assurance requirements. In 2011 , GlobalG.A.P. created a committee on animal welfare to define better standards that should go beyond minimum animal welfare legal requirements for pigs and broilers, also a check list with evaluating parameters for the welfare of pigs has been developed. GLOBALG.A.P., GlobalG.A.P. Animal Welfare Add-on. Webpage: https://www.globalgap.org/uk_en/for-producers/globalg.a.p.add-on/animal-welfare/ [Retrieved August 2, 2019]; GLOBALG.A.P., Animal Welfare Add-on Module for Pigs/Finishers Checklist. Webpage:

https://www.globalgap.org/.content/.galleries/documents/130214_gg_add-on_aw_pg_cl_v1_0_protected_en.pdf [Retrieved August 2, 2019].

${ }^{260}$ RYLAND, D., Animal Welfare Governance : Global G.A.P. and the Search for External Legitimacy. Journal of Environmental Law, 30 (3) (2018), 453-482, p. 460, 466 and 467. DOI: https://doi.org/10.1093/jel/eqy015.

261 Ibid., at 465.

${ }^{262}$ Legitimacy can be ensured through dialogue and cooperation between private and public governance structure. For example, public authorities establish guidelines that are operationalized through private governance standards, an example in the field of food is the Codex Alimentarius. In this way private governance standards act within the framework of public governance guidelines. HENSON \& HUMPHREY, supra note 256, at 106; BLATTNER, supra note 8, at 224.

${ }^{263}$ Ibid. BLATTNER; RYLAND, supra note 260, at 465.

${ }^{264}$ STUCKI, S., (Certified) Humane Violence? Animal Welfare Labels, the Ambivalence of Humanizing the Inhumane, and What International Humanitarian Law Has to Do with It, AJIL Unbound, 111 (2017), 277-281, p.278. DOI: https://doi.org/10.1017/aju.2017.65.

265 DALTON, J., Supermarkets 'Trick Customers into Buying Chickens that Suffered in Industrial Farming'. Webpage: https://www.independent.co.uk/news/uk/home-news/chicken-supermarket-offers-industrial-farming-price-asda-aldi-lidl-tescosainsbury-morrisons-a8758861.html [Retrieved August 5, 2019]. 
consideration of animals as profitable products. However, the fact that TNCs somehow respond to the demands of consumers by setting standards has positive implications. ${ }^{266}$ Those standards have created a private governance structure ${ }^{267}$ and transnational minimum requirements for the entire food supply chain that could partially fill legal voids at domestic and international level. ${ }^{268} \mathrm{TNCs}$ and standards certification entities, thanks to their economic power, can be extremely persuasive in obtaining that producers and suppliers in countries with low animal welfare standards comply with stricter standards of retailers and consumers from countries where legal requirements and cultural sensibility towards animals are higher. ${ }^{269}$ These dynamics could be described as a "race to the top" effect ${ }^{270}$ which, in the perspective of animal protection, should be channelled in a more efficient direction. For the sake of animals and sustainability, efficiency means excluding animals from the production process and finding alternatives to their exploitation. ${ }^{271}$ The political action of an international institution devoted to animal protection could facilitate this change by collaborating with the emerging plant-based sector. ${ }^{272}$ The focus on animal protection in self-regulating business codes of conduct would prioritize plant-based products instead of supporting animal farming and its supply chain. Plant-based business is functional to the safeguard of animals' interests because it completely removes animals from the economic equation and replace their exploitation with vegetable alternatives. This business model does not attempt to make production less cruel, nor to guarantee an "ethically" acceptable standard in the use of animals; on the contrary, it changes the production paradigm by inventing new solutions. The plant-based food industry has rapidly grown ${ }^{273}$ thanks also to meat and dairy producers and TNCs investing in this sector. ${ }^{274}$ Flexitarian consumers together with vegetarians and vegans are driving the global expansion of the plant-based food sector for ethical, environmental and health reasons. ${ }^{275}$ If the sensibility towards animal

${ }^{266}$ MORATH, supra note 252, at 29. Production is somehow driven by consumers' choices. About the relation between labels and certifications and consumers choices see MEYBECK, A., GITZ, V., Signs to Choose: Voluntary Standards and Ecolabels as Information Tools for Consumers. In A. MEYBECK, S. REDFERN, Voluntary Standards for Sustainable Food Systems: Challenges and Opportunities (Rome 2013).

${ }^{267}$ MORATH, supra note 252 , at 24 .

${ }^{268}$ See for example the effects of the National Farm Animal Care Council (NFACC) Code process in Canada, SANKOFF, supra note 211, at 324-28. The soft law self-regulating instruments might also be integrated into hard law regulation by national authorities.

269 The persuasion of the economic power and private governance standards as International Featured Standards (IFS), GlobalG.A.P., British Retail Consortium (BRC), Safe Quality Food (SQF) and Global Food Safety Initiative (GFSI) could somehow implement a change in production methods and consumers' habits that states and public standards might not be able to impose. About the relation between public and private standards see SANTACOLOMA, P., Nexus Between Public and Private Food Standards: Main Issues and Perspectives. In A. MEYBECK, S. REDFERN, Voluntary Standards for Sustainable Food Systems: Challenges and Opportunities (Rome 2013). The adoption of private standards is voluntary, however retailers might require that their suppliers provide certified products and by doing so they automatically enforce the adoption of certain standards. As a result, standards and certifications can exert a strong influence on the entire supply chain by shaping and raising the bar of criteria of quality, safety and access to market. See HENSON \& HUMPHREY, supra note 256, at 100- 101; RYLAND, supra note 260, at 460.

270 BLATTNER, supra note 8 , at 60 .

${ }^{271}$ The food industry should invest more in meat, dairy and eggs substitutions and shift towards a plant-based production, and fashion industry should use plant-based textiles to replace fur, leather, wool and silk. See for example WICKER, A., Fashion's Long Hunt for the Perfect Vegan Leather. Webpage: https:/www.voguebusiness.com/technology/vegan-faux-leather-stella-mccartney-pradaversace [Retrieved August 26, 2019]; TODESCHINI, B. V., CORTIMIGLIA, M. N., CALLEGARO-DE-MENEZES, D., \& GHEZZI, A., Innovative and Sustainable Business Models in the Fashion Industry: Entrepreneurial Drivers, Opportunities, and Challenges. Business Horizons, 60(6) (2017), 759-770; CAMILLI, S., 8 Eco-Friendly Vegan Fabrics to Replace Wool - Without Plastic (February 21, 2019). Webpage: https://www.plantbasednews.org/lifestyle/8-eco-friendly-vegan-fabrics-replace-wool-without-plastic [Retrieved August 26, 2019].

272 HENSON, S., The Role of Public and Private Standards in Regulating International Food Markets. Journal of International Agricultural Trade and Development, 4 (2008), 63-81, p. 65.

${ }^{273}$ UBS, Plant-based Protein is Disrupting Meat Markets. Webpage:

https://www.ubs.com/global/en/wealth-management/marketnews/financial-education/article.1442540.html [Retrieved August 25, 2019]; ROCKEMAN, O., Plant-Based Sales Are Rising. If Only We Could Pick a Definition. Webpage: https://www.bloomberg.com/news/articles/2019-07-16/plant-based-sales-are-rising-if-only-we-could-pick-a-definition [Retrieved August 25, 2019]. According to Deloitte analysts "[t]he global meat and dairy sector is currently going through an unprecedented level of competition and disruption, driven by the growth of viable plant-based alternatives across many categories. Gone are the days when plant-based alternative products were for the niche consumer and warranted limited shelf space". DELOITTE, Plant-based Alternatives Driving Industry M\&A., p.1. Webpage: https://www2.deloitte.com/content/dam/Deloitte/uk/Documents/consumer-business/deloitteuk-plant-based-alternatives.pdf [Retrieved October 26, 2019].

${ }^{274}$ For some examples of companies investing in meat substitutes see FELSTED, A., Beyond Meat Should Take Notes From Juul. Webpage: https://www.bloomberg.com/opinion/articles/2019-08-23/big-food-s-embrace-of-fake-meat-faces-obstacles-like-vaping [Retrieved August 25, 2019]. About Danone investment strategy in diary free products see AXWORTHY, N., Danone CEO: PlantBased to Become as Big as Dairy. Webpage: https://vegnews.com/2019/5/danone-ceo-plant-based-to-become-as-big-as-dairy [Retrieved August 25, 2019].

${ }_{275}$ DELOITTE, supra note 273, at 2. The EAT-Lancet Commission on healthy diets from sustainable food systems recommends to increase the consumption of plant-based food and to reduce the intake of animal source food, WILLETT, W., ROCKSTRÖM, J., LOKEN, B., et al.,Food in the Anthropocene: the EAT-Lancet Commission on Healthy Diets from Sustainable Food Systems. The Lancet, 393 (2019), 447-492, p. 448. DOI: https://doi.org/10.1016/S0140-6736(18)31788-4. The New Zealand Health Ministry has officially endorsed the recommendation of a plant-based diet to reduce consumption of red meat as a measure to combat climate 
protection or the ethical and health arguments are not enough to change consumers' behaviours and TNCs strategy, the economic and technical arguments could contribute to the reduction of animal exploitation on purely rational and economic grounds. ${ }^{276}$ The traditional animal meat supply is expected to fall by $33 \%$ by 2040 and will be replaced by cultured meat and plant-based products. ${ }^{277}$ With the advent of plant based business, the exploitation of animals would become anti-economical and therefore will be gradually abandoned and replaced with more efficient and sustainable vegetable solutions.

The proposed organization on animal protection should acknowledge the existing private business initiatives about animal welfare and plant-based production, and should insert them in the more general framework of animal protection ${ }^{278}$ with the aim of facilitating the transition from an economic system based on animal exploitation to a new paradigm that dismisses the use of animals as profitable resources. The involvement of business actors will be crucial to guarantee a tripartite negotiation and provide concrete inputs that will contribute to the enforcement and direct applicability of norms and decisions of the organization. It might help industry to give consistency to their claimed interest in animal welfare. ${ }^{279}$ Thanks to social pressure and consumers demand, animal welfare could become part of the social responsibility schemes of private business $^{280}$ and of a new framework of sustainability that takes into account animal protection principles. The direct participation of private business actors in the negotiation of policies and regulations about animal protection would achieve more efficient and enforceable outcomes and would provide practical and technical solutions to the problems that might come up.

Although business participation in the organization could be an asset, at the moment a full membership status including the right to vote might entail relevant risks and might not be beneficial. Given the contemporary economic context where the majority of business actors have an interest in the exploitation of animals, foreseeing the right to vote for business representatives might be hazardous because it would give them the power to heavily influence the decision making process. ${ }^{281}$ It would also undermine the effectiveness of the proposed organization in advancing animal protection and it would impede the transition towards the replacement of animal products with vegetable or other non-animal alternatives.

\subsubsection{Cooperation with other international organizations}

Since animal protection is characterized by interdependency among multiple disciplines, collaborations with other IOs could be fundamental for the proposed organization on animal protection in order to reach its goals. As UNEP coordinates environmental protection initiatives, ${ }^{282}$ the proposed organization on animal protection should coordinate the actions of other IOs that marginally deal with animal related matters. As in the case of UNEP Environment Assembly, ${ }^{283}$ representatives of interested UN specialized agencies, bodies, and other IOs could participate in the governing body of the organization without the right to vote. Cooperation between the organization on animal protection and other IOs could take the form of specific projects, and could develop strategies of networking and policies. The partnership could be regulated through memoranda of collaboration. ${ }^{284}$ Possible areas of cooperation could be foreseen with WTO, OIE, FAO, and WHO, which have a clear interest in the regulation of animal protection.

change, NEW ZEALAND MINISTRY OF HEALTH, Sustainability and the Health Sector, p. 16. Webpage: https://www.health.govt.nz/publication/sustainability-and-health-sector [Retrieved August 25, 2019]. The same message is supported by the latest UN Intergovernmental Panel on Climate Change (IPCC) report on Climate Change and Land. IPCC, Climate Change and Land: an IPCC Special Report on Climate Change, Desertification, Land Degradation, Sustainable Land Management, Food Security, And Greenhouse Gas Fluxes in Terrestrial Ecosystems, chapter 5, p. 5- 76. Webpage: https://www.ipcc.ch/srccl-report-downloadpage/ [Retrieved August 26, 2019].

276 "The combination of the growing number of consumers looking to eat plant-based alternatives, and the significant investment in new product innovation, is having a spiralling effect, driving the large growth in the overall market. This trend is expected to continue to accelerate". DELOITTE, supra note 273 , at 3.

${ }^{277}$ GERHARDT, C., SUHLMANN, G., ZIEMSSEN, F., DONNAN, D., WARSCHUN, M., \& KÜHNLE, H., How Will Cultured Meat and Meat Alternatives Disrupt the Agricultural and Food Industry?, ATKearney, p. 17. Webpage :

https://www.atkearney.com/documents/20152/2795757/How+Will+Cultured+Meat+and+Meat+Alternatives+Disrupt+the+Agricult ural+and+Food+Industry.pdf/06ec385b-63a1-71d2-c081-51c07ab88ad1?t=1559860712714 [Retrieved 26 October, 2019].

${ }^{278}$ BLATTNER, supra note 8 , at 199.

${ }^{279}$ RANSOM, supra note 253, at 26; MAIN, supra note 253; HENSON \& HUMPHREY, supra note 256, at 101.

${ }^{280}$ MORATH, supra note 252, at 26; BLATTNER, supra note 8, at 219- 220.

${ }^{281}$ PETERS, supra note 157 , at 156.

${ }^{282}$ UNGA, supra note 69 , at preamble; see also UNEP, supra note 70.

${ }^{283}$ UNEP, supra note 75 , at rule 69 p. 16.

${ }^{284}$ See for example the cooperation agreements between OIE and other IOs. OIE, Cooperation Agreements Between the OIE and Intergovernmental Organisations and Other International Nongovernmental Organisations. Webpage: https://www.oie.int/aboutus/key-texts/cooperation-agreements/ [Retrieved May 9, 2020]. 
The collaboration with WTO would focus on international trade law, which has a deep influence on the consideration of animals as tradable objects. As Blattner and Kelch have pointed out, the WTO law should be further analysed to explore under which conditions it offers the possibility to advance animal protection. ${ }^{285}$ Through this partnership the proposed organization should pursue a crucial objective: extending the process of de-objectification of animals to international trade law. The collaboration between the two organizations should clarify how to conciliate animal welfare domestic requirements with the provisions of the General Agreement on Tariffs and Trade (GATT) ${ }^{286}$ in order to avoid a race to the bottom in animal welfare. According to the most favoured nation principle (art. I GATT), the most favourable conditions accorded by the importing country to a given nation should be equally offered to all other nations trading with that country. ${ }^{287}$ Under articles III:1 and III:2 GATT, any attempt to protect domestic animal welfare standards by imposing tariffs, taxes or quantitative restrictions on imported products produced using lower animal welfare standards could be considered as negatively affecting trade since it would impose restrictions and obstacles to imports. ${ }^{288}$ Art. III:4 GATT introduces the principle of the likeness of product for the application of no less favourable treatment than domestic products. ${ }^{289}$ The likeness of animal products is strictly intertwined with the unsettled question of whether they could be considered, and thus treated, differently according to the level of animal welfare standards used during the production process. ${ }^{290}$ This is relevant for the application of restrictive trade measures to imported animal products that do not comply with domestic animal welfare standards, and for the consequent risk of a race to the bottom. ${ }^{291}$ Art. XX GATT specifies the general exceptions that justify the nonadherence to the treaty; the most relevant for animal protection are: the necessity to protect public morals; the necessity to protect human, animal or plant life or health; conservation of exhaustible natural resources. The WTO Dispute Settlement Body (DSB) has recognized that animal welfare concerns public morals and therefore it can be considered as a valid exception according to art. XX(a) GATT. ${ }^{292}$ Whether the exception about human, animal and plant life or health applies also to animal welfare has not been clarified by WTO and it is debated by scholars. ${ }^{293}$ The exception about exhaustible natural resources is relevant because animals are sometimes considered as such, as stated in a number of cases by WTO DSB. ${ }^{294}$

According to the Agreement on Technical Barriers to Trade (TBT) ${ }^{295}$ and the Agreement on the Application of Sanitary and Phytosanitary Measures (SPS), ${ }^{296}$ in order to prevent obstacles and facilitate trade, states should orient themselves towards harmonized international standards based on scientific evidence. ${ }^{297}$ The international standards recognized by TBT and SPS are used by the DSB as a tool for the interpretation

\footnotetext{
${ }^{285} \mathrm{KELCH}$, supra note 11, at 239; BLATTNER, supra note 8, at 88.

${ }^{286}$ General Agreement on Tariffs and Trade (GATT) (adopted October 30, 1947) 55 UNTS 194.

287 This principle was invoked by Canada and Norway against the EU decision prohibiting the importation of seal products. The WTO Appellate Body recognised the violation of the most favoured nation rule of the GATT because an advantage was recognized only to Greenland (which is not considered part of the EU) and denied to Norway and Canada. See WTO Appellate Body Report, supra note $34, \S 5.95$ p. 122.

${ }^{288}$ BLATTNER, supra note 8, at 91, 94-99; see also WTO Panel Report, US-Restrictions on Imports of Tuna, WTO Doc. DS21/R39S/155 [Tuna /Dolphin I, Panel Report] and WTO Panel Report. US-Restrictions on Imports of Tuna, WTO Doc. DS29/R-39S/155 [Tuna /Dolphin II, Panel Report].

${ }^{289}$ The definition of "likeness" is not provided in international trade law and is determined on a case-by-case basis. Ibid. BLATTNER, at 97.

${ }^{290}$ Ibid., at 100 - 106. The opinion of the WTO Panel Report on the Tuna /Dolphin I case suggested that process and methods of production should not be considered as criteria to distinguish products and determine their "likeness". However the Panel Report on the Tuna /Dolphin I case was not adopted, therefore cannot be considered as an official and accepted interpretation of GATT provisions. As highlighted by Blattner, the interpretation of art. III GATT should be updated in order to consider the current public concerns about animal welfare.

${ }^{291}$ Ibid.; KELCH, supra note 11, at 268.

${ }^{292}$ WTO Appellate Body Report, supra note 34, at $131 \S 5.137-5.139$.

${ }^{293} \mathrm{KELCH}$, supra note 11 , at 257; BLATTNER supra note 8, at 111 and 112 .

${ }^{294}$ DSB relevant cases on this issues are: WTO Panel Report, US- Prohibition of Imports of Tuna and Tuna Products from Canada, WTO Doc. L/5198- 29S/91 (adopted February 22, 1982) [US-Tuna I, panel Report], §4.9; WTO Panel Report, Canada- Measures Affecting Exports of Unprocessed Herring and Salmon, WTO Doc. L/6268- 35S/98 (adopted March 22, 1988) [Herring and Salmon, Panel Report], §4.4; WTO Appellate Body Report. US- Import Prohibition of Certain Shrimp and Shrimp Products, , WTO Doc. WT/DS58/AB/R (adopted November 6, 1998) [Shrimp / Turtle I, AB Report], § 127. Blattner has noted that the consideration of animals as exhaustible resources becomes relevant for the conservation of animals as species that could become extinct, BLATTNER supra note 8 , at 110 .

${ }^{295}$ Agreement on Technical Barriers to Trade (TBT) (adopted April 15, 1994) 1868 UNTS 120.

${ }^{296}$ Agreement on the Application of Sanitary and Phytosanitary Measures (SPS) (adopted April 15, 1994) 1867 UNTS 493.

${ }^{297}$ Ibid., preamble, art. 3 and art. 5; TBT, supra note 295, preamble; WTO, Understanding the WTO: the Agreements Standards and safety. Webpage: https://www.wto.org/english/thewto_e/whatis_e/tif_e/agrm4_e.htm\#TRS [Retrieved October 8, 2019]. States can apply stricter sanitary and phytosanitary measures than international standards only if they are based on scientific justifications and on a risk assessment analysis.
}

90 Derecho Animal. Forum of Animal Law Studies, vol. 11/2 
of WTO treaties. In this perspective, the activity of standard- setting and enhancement of scientific knowledge of the proposed organization on animal protection could influence the interpretation of international trade law in favour of animals.

OIE

The partnership with OIE might focus on the further development of guidelines on animal welfare and health, and on defining strategies of control and protocols for the health management of stray cats and dogs, and alien species. Projects about ethology of pets species could also be undertaken to improve animals quality of life. The proposed organization on animal protection could join the OIE-FAO-WHO collaboration on the reduction of health risks deriving from the human-animal ecosystems interaction. ${ }^{298}$ The organization on animal protection should engage in a dialogue with OIE about including the rejection of arbitrary killing of animals for human use in the definition of animal welfare. ${ }^{299}$

FAO

The definition of a common vision of sustainability ${ }^{300}$ in agriculture that includes principles of animal protection should constitute the priority in the collaboration with FAO. The focus should be on methods of food production that guarantee nutritional security and, at the same time, combine protection of animals through the gradual reduction (until the exclusion) of animal exploitation in agriculture. One of FAO's goals is the transition toward a sustainable agricultural system in line with SDGs vision. ${ }^{301}$ So far FAO seams to focus on technology development, improvement of efficiency in production, better management of manure, efficient use of energy and recycling to mitigate the negative environmental impact of livestock and aquaculture. ${ }^{302}$ These measures however do not tackle the root causes of the problem. Rather, they safeguard the current economic and food production model based on the use of animals as economic products. ${ }^{303}$ In the international debate about sustainability and food security, the theme of animal protection has not received the attention that it deserves yet. Through the partnership with FAO, the proposed organization on animal protection should ensure the consideration of principles of animal protection in the development of new sustainable agricultural models. This implies a shift towards a food production system that does not consider animals as exploitable resources. Other relevant aspects for the collaboration between the proposed institution

\footnotetext{
${ }^{298}$ FAO, OIE, WHO, The FAO-OIE-WHO Collaboration: Sharing Responsibilities and Coordinating Global Activities to Address Health Risks at the Animal-Human-Ecosystems Interfaces. Webpage:

https://www.who.int/foodsafety/zoonoses/final_concept_note_Hanoi.pdf?ua=1 [Retrieved October 6, 2019].

${ }^{299}$ See the definition of animal welfare provided by Art. 7.1.1 of OIE Terrestrial Animal Health Code, supra note 7.

${ }^{300}$ FAO has published numerous reports about the negative environmental impact of livestock sector, see STEINFELD, supra note 22. FAO has also developed a tool for calculating livestock carbon footprint see FAO, Sizing up Livestock Farming's Carbon Footprint: Tool Helps Livestock Farmers to Improve Productivity and Reduce Greenhouse Gas Emissions. Webpage: http://www.fao.org/news/story/en/item/429417/icode/ [Retrieved October 4, 2019].

${ }^{301}$ FAO sustainability vision is currently based on 5 principles: efficient use of natural resources; conservation, protection and enhancement of natural resources; improvement of rural livelihood, equity and social wellbeing; enhancement of people, community and ecosystems' resilience; responsible and effective governance. Starting from these principles a common sustainability vision that conciliates agricultural development with animal protection could be developed. See FAO, Sustainable Food and Agriculture. Webpage: http://www.fao.org/sustainability/en/ [Retrieved October 3, 2019].

${ }^{302}$ FAO, Tackling Climate Change Through Livestock. Webpage:

http://www.fao.org/ag/againfo/resources/en/publications/tackling_climate_change/index.htm [Retrieved October 4, 2019]. For further information about FAO mitigating measures see GERBER, P., STEINFELD, H., HENDERSON, B., MOTTET, A., OPIO, C., DIJKMAN, J., TEMPIO, G., Tackling Climate Change Through Livestock - A Global Assessment of Emissions and Mitigation Opportunities (Rome 2013); FAO, Livestock Solutions for Climate Change. Webpage: http://www.fao.org/3/a-i8098e.pdf [Retrieved October 4, 2019].

${ }^{303}$ FAO Director has stated that livestock "can play a key role in improving the lives of millions by: providing the world with sufficient and reliable supplies of meat, milk, eggs and dairy products; increasing the direct consumption of animal-source foods; helping to generate income and create employment; and strengthening the assets that rural households use to achieve their livelihood objectives. It can also help improve children's cognitive and physical development as well as school attendance and performance; empower rural women; improve natural resource-use efficiency; broaden access to clean and renewable energy; and support sustainable economic growth. Finally, it can generate fiscal revenue and foreign exchange; create opportunities for value addition and industrialization; stimulate smallholder entrepreneurship, close inequality gaps; promote sustainable consumption and production patterns; increase the resilience of households to climate shocks; and bring together multiple stakeholders to achieve all these goals". FAO, Transforming the Livestock Sector through the Sustainable Development Goals. Webpage: http://www.fao.org/3/ca1201en/CA1201EN.pdf [Retrieved October 4, 2019].
} 
on animal protection and FAO are the Codex Alimentarius ${ }^{304}$ and the welfare of farmed animals. ${ }^{305}$

\section{WHO}

The partnership with the WHO might focus the One Health approach, multi-resistance to antimicrobials, and nutritional guidelines. The consideration of animal protection in the health sector could also be extended to collateral aspects such as the physical and psychological health of slaughterhouses workers and the economic health costs caused by the consumption of animal products. The One Health ${ }^{306}$ approach recognizes the interaction among humans, animals and the environment in the determination of health. A tripartite coalition among WHO, FAO and $\mathrm{OIE}^{307}$ is currently developing a tool for the risk assessment of zoonosis considering the human-animal-environment interface. ${ }^{308}$ The proposed organization on animal protection could join this coalition to ensure that the interests of animals are taken into consideration in the further development of the One Health approach. One of the major issue in One Health is the problem of antimicrobial resistance ${ }^{309}$ which is strictly related to the use of antibiotics and antimicrobials in livestock. ${ }^{310}$ Concerning the nutritional aspects, WHO is already promoting the adoption of healthy diet based on the consumption of fruits and vegetables, and on the reduction of fats intake to less than $30 \%$ of total energy intake preferably from unsaturated fats (present in fish, and vegetable food such as: avocado, nuts, and in sunflower, soybean, canola and olive oils) rather than from saturated fats (present in palm and coconut oil and in animal food products: fatty meat, butter, cream, cheese, ghee and lard). ${ }^{311}$ By collaborating with WHO on nutritional guidelines, the proposed organization on animal protection might advocate for further reduction of the consumption of food animal products. In the Global Action Plan for the Prevention and Control of Noncommunicable Diseases 2013-2020, WHO considers the use of fiscal and economic tools - supported by scientific evidence - "to improve access to healthy dietary choices and create incentives for behaviors associated with improved health outcomes and discourage the consumption of less healthy options". ${ }^{312}$ So far WHO has focused on tax on sugar, ${ }^{313}$ the possibility to use taxes and subsidies to favor plant-based food options over animal products could be further explored by the future organization on animal protection in collaboration with WHO. Some scholars have considered the possibility to introduce a health-motivated tax on meat. ${ }^{314}$ Further analysis are needed also on dairy products and eggs.

\footnotetext{
${ }^{304}$ FAO and WHO collaborate to the development of the Codex Alimentarius a set of standards and guidelines for food safety, production and trade that aims to protect consumers' health and guarantee fairness in food trade. The Codex has been recognized by the SPS as reference standard for the resolution of trade dispute. FAO, WHO, About Codex Alimentarius. Webpage: http://www.fao.org/fao-who-codexalimentarius/about-codex/en/ [Retrieved October 4, 2019].

305 The current challenge for FAO "is to increase food animal production while simultaneously ensuring good animal welfare and protecting food security”, VAPNEK, J., CHAPMAN, M., Legislative and Regulatory Options for Animal Welfare, FAO Legislative Study 104 (2011), preface. To address this challenge FAO has created the "Gateway to Farm Animal Welfare" where animal welfare is defined as "a global common good which forms an integral part of a responsible development of the livestock sector". FAO, About the Gateway. Webpage: http://www.fao.org/ag/againfo/themes/animal-welfare/aw-abthegat/aw-whaistgate/en/ [Retrieved October 4, 2019].

${ }^{306}$ WHO, One Health. Webpage: https://www.who.int/features/qa/one-health/en [Retrieved, October 6, 2019].

${ }^{307}$ Ibid. This tripartite collaboration has the aim "to promote multi-sectoral responses to food safety hazards, risks from zoonoses, and other public health threats at the human-animal-ecosystem interface and provide guidance on how to reduce these risks". See also FAO, OIE, WHO, supra note 298.

${ }^{308}$ FAO, OIE, WHO, Conducting National Joint Risk Assessment: a Tripartite Operational Tool. Webpage: https://extranet.who.int/sph/docs/file/3526 [Retrieved October 6, 2019].

${ }^{309}$ WHO, supra note 26; MARSHALL \& LEVY, supra note 26.

${ }^{310}$ FAO, supra note 22, at 7; WHO, Global Action Plan on Antimicrobial Resistance, p. 3. Webpage: https://apps.who.int/iris/bitstream/handle/10665/193736/9789241509763_eng.pdf?sequence=1 [Retrieved October 6, 2019].

${ }^{311}$ Saturated fat should be reduced to less than $10 \%$ of total energy intake. WHO, Healthy Diet Fact Sheet N 394 . Webpage: https://www.who.int/nutrition/publications/nutrientrequirements/healthy_diet_fact_sheet_394.pdf?ua=1 [Retrieved October 7, 2019]; WHO, Global Strategy on Diet, Physical Activity and Health. Webpage: https://www.who.int/dietphysicalactivity/diet/en/ [Retrieved October 7, 2019].

312 WHO, Global Action Plan for the Prevention and Control of Noncommunicable Diseases 2013-2020, p. 33. Webpage:

https://apps.who.int/iris/bitstream/handle/10665/94384/9789241506236_eng.pdf?sequence=1 [Retrieved October 7, 2019]; WHO, Fiscal Policies for Diet and Prevention of Non-communicable Diseases. Webpage:

https://apps.who.int/iris/bitstream/handle/10665/250131/9789241511247-
}

eng.pdf;jsessionid=4DF13B5CA5E8E23B299F67192BFF8DB8? sequence=1 [Retrieved October 7, 2019].

313 WHO, Fiscal Policies for Diet and the Prevention of Non-Communicable Diseases. Webpage: https://www.who.int/dietphysicalactivity/publications/fiscal-policies-diet-prevention/en/ [Retrieved October 7, 2019].

314 SPRINGMANN, M., MASON-D'CROZ, D., ROBINSON, S., WIEBE, K., GODFRAY, H., RAYNER, M., \& al., Healthmotivated Taxes on Red and Processed Meat: A Modelling Study on Optimal Tax Levels and Associated Health Impacts. PLoSONE, 13(11) (2018). DOI: https://doi.org/10.1371/journal.pone.0204139.

92 Derecho Animal. Forum of Animal Law Studies, vol. 11/2 


\subsection{Functioning and competences}

On the basis of the model of the EU Animal Welfare Platform, the proposed organization could constitute a forum to foster dialogue among stakeholders. The mechanism of participation and the voting procedures will define the power relationships among actors, each with its own interests, nature, and experience. A tripartite model of negotiation among member states, NGOs, and business representatives could facilitate cooperation and co-regulation of animal protection issues. As already discussed, the delicate issue of the attribution of the right to vote to NGOs and business actors will be crucial for the definition of the membership criteria. The mechanisms for the distribution of votes among the various members of the governing body should be decided during the negotiating process. In order to preserve the legitimacy of the organization, it is important that criteria of fair and balanced representation are respected, that a party does not take control over the others, ${ }^{315}$ and that the economic power of business stakeholders does not unfairly influence the decision-making process. As mentioned, the participation of TNCs and business actors could present some risks. ${ }^{316}$ Clearly their involvement should be channelled toward the protection of animals, which means that the economic interest has to be re-interpreted in way that rejects the exploitation of animals and safeguards their interests.

An important point that should be discussed in the definition of the code of conduct of the organization is the voting procedure in the governing body. Decisions could be approved by majority as in the UNEP Environment Assembly, or by consensus as in the case of the UNFF governing body. A majority mechanism would provide more autonomy and a faster decision making process. However, decisions adopted through a majority driven mechanism could be perceived as "imposed" by the dissenting minority. While decisions adopted by consensus require a longer negotiation, they take into consideration all participants' opinions in the definition of the final result. On one hand, decisions by consensus guarantee more solid agreements and future compliance; on the other hand, the long negotiating process might slow down and reduce the efficacy of the organization. Also, decisions adopted by consensus are more likely to be less ambitious and less progressive. A mixed system could be foreseen where members decide which type of decisions require consensus and which can be approved by majority.

According to the outlined mandate of the organization, an important activity would be the production of knowledge about animals and our interaction with them. In this respect, the UNEP experience with GEO could provide useful inputs. Periodic publications and assessment reports about the state of animal protection in the world and studies about animal related issues will require an effort of collaboration among members, academic experts, research centres, national authorities, international institutes, and NGOs. The studies could be useful to highlight major issues in animal protection, share and advance knowledge, and identify problems and possible solutions. They would also provide a scientific ground for future policies, recommendations, and best practices. The neutrality and independence of the organization are vital in order to provide credible information and also for the organization to be trusted. ${ }^{317}$ Scientific and reliable analysis favours the neutrality of the institution by proving that the decisions and the agenda of the organization are based on scientific data.

Working groups on specific topics could be created following the model of the EU Animal Welfare Platform. The working groups would constitute the place where the actual work of the organization is carried out. They could be established by decision of the permanent board and participation should be open to representatives of all members of the organization. Given the interdependency of many themes of animal protection, interdisciplinary working groups could involve several divisions. The working groups would develop new ideas, enhance knowledge, and propose concrete initiatives to ameliorate animal protection. The information derived from the reporting activity might constitute a starting point for developing ad hoc initiatives and projects supervised by the working groups to address specific regional or domestic problems.

A possible approach to tackle some of the main problems related to animal protection is the conclusion of multilateral treaties. Examples of animal protection treaties exist at regional level. The Council of Europe $(\mathrm{CoE})$ has developed conventions regulating the use of animals in farming ${ }^{318}$ transportation, ${ }^{319}$ procedures of slaughter, ${ }^{320}$ pets, ${ }^{321}$ and use of animals in research experiments. ${ }^{322}$ These conventions cover only some

\footnotetext{
315 About the balance of power of parties in shared decision making process on animal welfare regulating bodies in Canada and New Zealand see SANKOFF, supra note 211, at 37-40.

316 PETERS, supra note 157 , at 156.

317 ABBOTT \& SNIDAL, supra note 190, at 20.

318 Council of Europe, European Convention on the Protection of Animals Kept for Farming purposes (adopted March 3, 1976) ETS No.087.

${ }^{319}$ Council of Europe, supra note 6.

${ }^{320}$ Council of Europe, European Convention for the Protection of Animals for Slaughter (adopted May 10, 1979) ETS No.102.

${ }^{321}$ Council of Europe, European Convention for the Protection of Pet Animals (adopted November 13, 1987) ETS No.125.

322 Council of Europe, European Convention for the Protection of Vertebrate Animals used for Experimental and other Scientific
} 
components of animal protection, however they constitute a model that could be further developed and extended to a global scale. ${ }^{323}$ The proposed global organization on animal protection would play a key role in expanding the body of international animal law. It would promote the creation of multilateral conventions and soft law instruments by providing support in the negotiations. It would also have an impact on national norms, since it could provide assistance to member states in defining domestic animal law provisions in compliance with international standards. An important initiative in this regard is the Model Animal Welfare Act, ${ }^{324}$ a guiding legislation model created by the World Animal $\mathrm{Net}^{325}$ with the aim of providing a general template that could be adapted to local needs and facilitate the development of domestic legislation on animal welfare. ${ }^{326}$ This model was created for common and civil law legal systems, the project could be adopted by the new organization and further developed to encounter the need of religious legal systems, ${ }^{327}$ or other specific requirements that might arise. The legislative activity should be one of the main tasks of the organization and it could follow a temporal development with intermediate goals. In the beginning, the production of new norms will probably concern technical aspects with a less controversial nature. Albeit purely technical, these new legal instruments would develop a new sensibility towards animal protection and contribute to globally accepted minimum standards of protection. Following a spillover mechanism, the regulation of technical aspects could generate a cultural change in the consideration of animals that, in the medium or long term, will allow a more general codification of principles and values of animal protection in international instruments. This process should lead to the final affirmation of animal rights. The involvement of business actors and NGOs would add values to the new conventions enhancing the efficiency and direct applicability of the negotiated instruments. Some of the private standards that business actors have already developed could be integrated in the future treaties. Also, the expertise of NGOs could be useful to identify and tackle concrete and specific problems, and to bring successful experiences and lessons learned. An example in this sense, even though at regional level, is the work of the Eurogroup for Animals, which has developed a set of model legal provisions about animal welfare that have been proposed to be included in EU trade agreements with third countries. ${ }^{328}$ A similar document could be created on a wider level by the new organization and proposed to partner IOs as a tool to integrate animal protection provisions in various fields of negotiation. As intended in the case of UNEP, in order to avoid a chaotic development of animal law, the new organization should maintain a role of coordinator of the multilateral animal law agreements and their institutions. The new organization should have an anchor role in the global animal protection governance structure that it will have contributed to create. As in the case of UNEP with MEAs, the new institution could host the secretariats of new conventions on animal protection, providing an administrative structure they can rely upon.

In the international society, there is no executive body responsible for the enforcement of international norms negotiated in treaties. ${ }^{329}$ The proposed organization on animal protection could offer assistance to its members for the implementation of animal protection standards by providing recommendations, technical information, and instructions on treaty provisions. When needed, it could also promote specific projects in the various countries. A reporting, monitoring, and review mechanism could be considered to improve enforcement and provide information about actors' non- compliance with the decisions of the proposed institution. Member states and business actors should submit regular reports about the state of animal protection and compliance with international standards in their territory. A standard methodology of reporting should be put in place in order to harmonise data and information transmission from all member states. These reports could be revised by an independent experts committee that should provide recommendation for improvement. A similar mechanism is already in place in some of the MEA conventions managed by UNEP, such as the Barcelona Convention for the Protection of the Marine Environment and the Coastal Region of the Mediterranean, ${ }^{330}$ the Basel Convention on the Control of Transboundary Movements of Hazardous

Purposes (adopted March 18, 1986) ETS No.123.

323 BLATTNER, supra note 10, at 28-29.

${ }^{324}$ LENNKH, S., COX, J. H., Model Animal Welfare Act. Webpage:

http://worldanimal.net/images/stories/documents/Model_AWA/WAN-Model-Animal-Welfare-Act.pdf [Retrieved August 2, 2019].

${ }^{325}$ World Animal Net. Webpage: http://worldanimal.net/about [Retrieved August 2, 2019 ].

${ }^{326}$ LENNKH \& COX, supra note 324 , at 5.

327 This might be relevant for Muslim countries with legal systems based or influenced by Sharia law.

${ }^{328}$ Eurogroup for Animals Model Animal Welfare Provisions for EU Trade Agreements- Trade \& Animal Welfare Project. Webpage: http://www.eurogroupforanimals.org/wp-content/uploads/E4A-MAWP_Report-screenOKKKK.pdf. [Retrieved August 2, 2019].

329 TREVES, supra note 152 , at 24.

330 UNEP, Coordinating Unit for the Mediterranean Action Plan Governing bodies. Webpage: https://web.unep.org/unepmap/whowe-are/institutional-framework/governing-bodies [Retrieved April 25, 2020]. 
Wastes and their Disposal, ${ }^{331}$ and other IOs. ${ }^{332}$ NGOs' independent reports could also incentivise states and business actors to undertake further efforts to comply with international standards. ${ }^{333} \mathrm{~A}$ complaint mechanism could also be envisaged, where individuals, NGOs or any other entity can submit a complaint for alleged violation of the animal protection standards. The experts committee should assess the complaints and suggest further steps.

Typical dispute settlement mechanisms cited in art. 33 of the UN Charter ${ }^{334}$ are: negotiation, enquiry, mediation, conciliation, arbitration, and judicial settlement. In addition to these mechanisms, the ombudsman and good offices can also be considered. The three organizations taken into consideration as models do not provide any useful reference in this regard. The proposed organization on animal protection, upon agreement among the parties, could offer its good offices, service as mediator, or provide assistance in a fact-finding commission. Concerning arbitration, a representative of animals should always be involved in the arbitration committee in order to guarantee that the interests of the animals are taken into due account during the process. Whether the panel should be a permanent body in the institution or established ad hoc on occasion of litigation can be established during the negotiation phase, the possibility to have an appeal level should also be defined. Another issue that has to be discussed is whether the dispute settlement body should be able to accept claims by all actors of the organization or only by states.

\section{Conclusions}

The establishment of a global institution on animal protection is a possible strategy to address the intrinsic global and holistic dimension of the current challenges regarding animal protection. This analysis has tried to respond to the question about how to create such organization by designing the main features of the institution and discussing possible working mechanisms. This final section presents the theoretical and practical implications of this project in terms of improvement for animal protection governance and regulations. The idea of an international institution for animal protection is a huge and ambitious project that goes far beyond the limited possibilities of this study; therefore, limitations of this work and future paths of research will be also presented across this section.

The proposed organization would assume a leadership role in animal protection and would provide a public institutional space where all different components of animal protection could interact and develop with an holistic global approach. For the realization of this objective, the proposed organization should work on the acquisition and publication of knowledge on animal related themes, it should strategically define a political agenda based on identified priorities of intervention, promote the law-making process at national and international level and guarantee tools of legal protection to animals, collaborate with other IOs on building institutional capacity and spreading a culture of respect and consideration of animals, and it could also engage in concrete projects in collaboration with states. In order to perform these tasks, the organization should be provided with an independent secretariat, a permanent board, and a plenary body based on universal membership of states and large participation of non-state actors. Thematic divisions will be in charge of specific areas of work and could be supported by working subgroups. A financing system should also be foreseen. The analysis of the three reference models has put into light critical aspects that should be taken into due consideration during the process of the creation of the organization: for example the issues of funding, membership and participation, and the institutional form given to the organization. Future research could investigate the contribution of NGOs in advancing animal protection and how to recognize this important role in terms of legitimacy in participating or being voting members of an international organization. It is time that public institutions support the work that NGOs have done so far and take over the responsibility to protect animals. The establishment of a global institution goes in the direction of developing a public governance structure in favour of animal protection. This organization should promote a change of paradigm in the consideration of animals and take a further step in the process of de-objectification of animals: from exploitable economic resources and tradable objects to sentient beings. The creation of an international organization on animal protection could have important implications for a new approach to sustainability that, beside human components, considers animals' interests. It could contribute to the definition of sustainable forms of food production systems and support new business models, such as the plant-based sector which is

\footnotetext{
${ }^{331}$ UNEP, Basel Convention Implementation \& Compliance Committee. Webpage:

http://www.basel.int/TheConvention/ImplementationComplianceCommittee/Overview/tabid/2868/Default.aspx [Retrieved July 27, 2019].

${ }^{332}$ ABBOTT \& SNIDAL supra note 190, at 17. The authors mention the example of ILO expert committee. This kind of compliance mechanism is also adopted by the UN Economic Commission for Europe (UNECE).

${ }^{333}$ ALVAREZ, supra note 17, at 1; PETERS, supra note 157, at 227-235. See also Sea Shepherd, supra note 212.

${ }^{334}$ Charter of the United Nations (adopted October 24, 1945), 1 UNTS 16, art. 33.
} 
concretely implementing animal protection by researching and developing alternatives to animal exploitation. Through partnership with international financial institutions, the existing policies on corporate social responsibility and the criteria for allocation of funds could be redefined to include principles of respect of animals. The involvement of business actors in the proposed organization aims to direct private governance standards towards the inclusion of animal protection principles in their requirements. The existence of soft law tools that mention animal protection would facilitate the development of hard law instruments both in domestic and international legal systems. These private business initiatives appear as mere technical and business-driven solutions and they could overcome cultural and social obstacles to the affirmation of animal protection principles. The change cannot occur by imposing beliefs or a cultural paradigm; rather, the proposed organization should offer concrete means and accessible and feasible options to implement animal protection. The cultural and religious perception of animals and the potential problems related to cultural relativism in the creation of an institution on animal protection could constitute another topic of additional investigation. The cultural aspect is also of primary importance for the negotiating process that should lead to the creation of the organization. In bringing together the various stakeholders, the debate about the consideration of animals in different cultures cannot be avoided.

This institution might reinforce the affirmation of animal protection as a socially relevant topic that deserves to be considered and discussed in the public forum. The establishment of a global institution for animal protection will contribute to the recognition of animals as sentient beings with fundamental interests in the preservation of their life and dignity. Such interests are relevant public issues deserving acknowledgement, protection, and a dedicated space in public institutions. This might be the driver of an institutional change towards a new paradigm of respect for animals and universal rights that recognise the right to existence of other living beings besides humans. 


\section{Bibliography}

- ABBOTT, K. W., SNIDAL, D., Why States Act through Formal International Organizations. The Journal of Conflict Resolution, 42(1) (1998, February), 3-32. DOI: https://doi.org/10.1177/0022002798042001001.

- ALEXANDER, S., DUDLEY, N., The Global Land Outlook. Bonn: United Nations Convention to Combat Desertification, (2017).

- ALVAREZ, J., International Organizations as Law-makers (Oxford 2005).

- BIERMANN, F., Reforming Global Environmental Governance. From UNEP Towards a World Environment Organization. In L. SWART, \& E. PERRY, Global Environmental Governance. Perspectives on the Current Debate (2007), Political Science, Multi-layered Governance in EUrope and Beyond (MLG).

- BLATTNER, C. E., Protecting Animals Within and Across Borders: Extraterritorial Jurisdiction and the Challenges of Globalization (New York 2019).

- BLATTNER, C. E., The Potential and Potential Limits of International Law in Regulating Animal Matters, 3 Mid-Atlantic Journal on Law and Public Policy, 10 (2015), 10-55.

- BOlliger, G., Animal Dignity Protection in Swiss Law - Status Quo and Future Perspectives (Zürich, Basel, Geneva 2016).

- BOUVARD, V., LOOMIS, D., GUYTON, K. Z., GROSSE, Y., GHISSASSI, F., BENBRAHIMTALLAA, L., \& al., Carcinogenicity of Consumption of Red and Processed Meat. Lancet Oncology, 16, (2015), 1599-1600. DOI: https://doi.org/10.1016/S1470-2045(15)00444-1.

- DARIAN-SMITH, E., Law and Societies in Global Contexts: Contemporary Approaches (New York 2013).

- De haAn, C., VAN Veen, T. S., BRANDEnburG, B., GAUThIER, J., LE GAll, F., MEARNS, R., \& SIMEON, M., Livestock Development: Implications for Rural Poverty, the Environment, and Global Food Security (2001), p. 65. Webpage: http://documents.worldbank.org/curated/en/306051468740146162/Livestock-developmentimplications-for-rural-poverty-the-environment-and-global-food-security [Retrieved August 7, 2019].

- DOMINGO, R., The New Global Law (Cambridge 2010).

- FEHL, C., FREISTEIN, K., (Un)making Global Inequalities: International Institutions in a Stratified International Society, Journal of International Relations and Development, (2020). DOI: https://doi.org/10.1057/s41268-020-00190-z.

- FOURNIER, L., Une Agence pour Défendre les Droits des Animaux à l'ONU, Nullius in Verba LSCV, 62 (2018, December).

- Gerber, P., STEINFEld, H., HENDERSON, B., MOTTET, A., OPIO, C., DiJKMAN, J., TEMPIO, G., Tackling Climate Change Through Livestock - A Global Assessment of Emissions and Mitigation Opportunities (Rome 2013).

- GIMÉNEZ- CANDELA, M., The De-objectification of Animals (I). dA Derecho Animal (Forum of Animal Law Studies), vol. 8/2 (2017), 1-4. DOI: https://doi.org/10.5565/rev/da.318.

- GIMÉNEZ-CANDELA, M., The De-objectification of Animals (II). dA Derecho Animal (Forum of Animal Law Studies), vol. 8/3 (2017), 1-2. DOI: https://doi.org/10.5565/rev/da.250.

- GIMÉNEZ-CANDELA, M., The De-objectification of Animals in Spanish Civil Code. dA Derecho Animal (Forum of Animal Law Studies) vol. 9/3 (2018), 28-47. DOI: https://doi.org/10.5565/rev/da.361.

- HAAS, P. M., Introduction: Epistemic Communities and International Policy Coordination, International Organization, vol. 46, no. 1 (1992), 1-35. DOI: https://doi.org/10.1017/S0020818300001442.

- HENSON, S., The Role of Public and Private Standards in Regulating International Food Markets. Journal of International Agricultural Trade and Development, 4 (2008), 63-81.

- HENSON, S., HUMPHREY, J., Private Standards in Global Agri-food Chains. IN A. MARX, M. MAERTENS, \& J. F. SWINNEN, Private Standards and Global Governance Economic, Legal and Political Perspectives (Cheltenham 2012).

- HUMPHREYS, D., Logjam: Deforestation and the Crisis of Global Governance (New York 2006).

- HUMPHREYS, D., The Creation of the United Nations Forum on Forests. Environmental Politics, 10 (2001), 160-166. DOI: https://doi.org/10.1080/714000519.

- HUMPHREYS, D., The United Nations Forum on Forests: Anatomy of a Stalled International 
Process. Global Environmental Change, 13 (2003), 319-323. DOI: https://doi.org/10.1016/S09593780(03)00008-6.

- HURD I., Constructivism. In C. REUS-SMITH, D. SNIDAL, The Oxford Handbook of International Relations (Oxford 2009). DOI: https://doi.org/10.1093/oxfordhb/9780199219322.003.0017

- IVANOVA, M., Assessing UNEP as Anchor Institution for the Global Environment: Lessons for the UNEO Debate, Yale Center for Environmental Law \& Policy, Working Paper No. 05/01, (2005).

- IVANOVA, M., Can the Anchor Hold? Rethinking the United Nations Environment Programme for the 21st Century. Forestry \& Environmental Studies Publications Series, 27 (2005).

- IVANOVA, M., Institutional Design and UNEP Reform: Historical Insights on Form, Function and Financing. International Affairs, 88(3) (2012), 565-584. DOI: https://doi.org/10.1111/j.14682346.2012.01089.x.

- KASPER, A.E.P., Global Governance 2.0. In: M. HOSLI, J. SELLESLAGHS (eds) The Changing Global Order. United Nations University Series on Regionalism, vol 17 (2020). Springer, Cham. DOI https://doi.org/10.1007/978-3-030-21603-0 14.

- KELCH, T. G., Globalization and Animal Law: Comparative Law, International Law, and International Trade (Alphen aan den Rijn 2011).

- KELCH, T. G., Towards Universal Principles for Global Animal Advocacy. Transnational Environmental Law, 5(1) (2016), 81-111. DOI: https://doi.org/10.1017/S2047102515000308.

- KHOR, M., Global Governance and the Environment. In J. DATOR, D. PRATT, \& Y. SEO, Fairness, Globalization, and Public Institutions: East Asia and Beyond (Honolulu 2006).

- KLABBERS, J., An Introduction to International Organizations Law (Cambridge 2015).

- KLABBERS, J., International Law (Cambridge 2017).

- LALL, R., Beyond Institutional Design: Explaining the Performance of International Organizations. International Organization, 71(02) (2017), 245-280.DOI:10.1017/s0020818317000066.

- MAGUIRE, R., Global Forest Governance: Legal Concepts and Policy Trends (Cheltenham 2013).

- MAIN, D. C., MULlAN, S., ATKINSON, C., COOPER, M., WRATHALL, J. H., \& BLOKHUIS, H. J., Best Practice Framework for Animal Welfare Certification Schemes. Trends in Food Science \& Technology, 37(2) (2014), 127-136. DOI: https://doi.org/10.1016/j.tifs.2014.03.009.

- MARTENS, K., Examining the (Non-)Status of NGOs in International Law, Indiana Journal of Global Legal Studies, 10 (2003), 1-24. DOI: https://doi.org/10.2979/gls.2003.10.2.1.

- MEYBECK, A., GITZ, V., Signs to Choose: Voluntary Standards and Ecolabels as Information Tools for Consumers. In A. MEYBECK, S. REDFERN, Voluntary Standards for Sustainable Food Systems: Challenges and Opportunities (Rome 2013).

- MICHA, R., WALlACE, S. K., \& MOZAFFARIAN, D., Red and Processed Meat Consumption and Risk of Incident Coronary Heart Disease, Stroke, and Diabetes Mellitus: A Systematic Review and Meta-Analysis, Circulation, 121 (2010), 2271-2283. DOI: https://doi.org/10.1161/CIRCULATIONAHA.109.924977.

- MORATH, S. J., Private Governance and Animal Welfare, George Washington Journal of Energy and Environmental Law, 9 (2018), 21-32.

- NAJAM, A., Developing Countries and Global Environmental Governance: From Contestation to Participation to Engagement. International Environmental Agreements: Politics, Law and Economics, 5(3) (2005), 303-321. DOI: https://doi.org/10.1007/s10784-005-3807-6.

- NAJAM, A., The Case Against a New International Environmental Organization. Global Governance, 9(3) (2003), 367-384. DOI: https://doi.org/10.1163/19426720-00903008.

- NAJAM, A., PAPA, M., TAIYAB, N., Global Environmental Governance: A Reform Agenda (Winnipeg 2006).

- NELlEMANN, C., MACDEVETTE, M., MANDERS, T., EICKHOUT, B., SVIHUS, B., PRINS, A. G., \& KALTENBORN, B. P., The Environmental Food Crisis - The Environment's Role in Averting Future Food Crises. A UNEP Rapid Response Assessment. United Nations Environment Programme, GRID-Arendal, (2009).

- NEUMANN, J.M., The Universal Declaration of Animal Rights or the Creation of a New Equilibrium Between Species, Animal Law (19) (2012), 91-109.

- MARSHALL, B. M., LEVY, S. B., Food Animals and Antimicrobials: Impacts on Human Health. Clinical Microbiology Reviews, 24(4) (2011) 718-733, DOI: https://doi.org/10.1128/CMR.0000211.

- MAXWELL, S. L., FULLER, R. A., BROOKS, T. M., WATSON, J. E., Biodiversity: The Ravages 
of Guns, Nets and Bulldozers, (2016, August 10). Webpage: https://www.nature.com/news/biodiversity-the-ravages-of-guns-nets-and-bulldozers-1.20381 [Retrieved August 17, 2019].

- MEYER-OHLENDORF, N., KNIGGE, M., A United Nations Environment Organization. In L. S. PERRY, Global Environmental Governance - Perspectives on the Current Debate (New York 2007).

- MINGST, K., Essentials of International Relations (New York 2001).

- OLSEN, S. H., \& ELDER, M., Strengthening International Environmental Governance by TwoPhased Reform of UNEP: Analysis of Benefits and Drawbacks, (2011). Webpage: https://www.files.ethz.ch/isn/143825/ieg_policy_report_s_olsen.pdf [Retrieved August 19, 2019].

- PETERS, A., Global Animal Law: What It Is and Why We Need It, Transnational Environmental Law, 5(1) (2016), 9-23. DOI: https://doi.org/10.1017/S2047102516000066.

- PETERS, A., Introduction to Symposium on Global Animal Law (Part I): Animals Matter in International Law and International Law Matters for Animals, AJIL Unbound, 111 (2017), 252-256. DOI: https://doi.org/10.1017/aju.2017.70.

- PETERS, A., Membership in the Global Constitutional Community. In J. KLABBERS, A. PETERS, \& G. ULFSTEIN, The Constitutionalization of International Law (New York 2010).

- RANSOM, E., The Rise of Agricultural Animal Welfare Standards as Understood through a NeoInstitutional Lens, International Journal of Sociology of Agriculture and Food, 15(3) (2007), 26-44.

- REBASTI, E., Beyond Consultative Status: Which Legal Framework for an Enhanced Interaction between NGOs and Intergovernmental Organizations?. In NGOs in International Law: Efficiency in Flexibility? (Cheltenham 2008).

- REGAN, T., The case for animal rights (Berkeley 1983).

- RITTBERGER, V., ZANGL, B., KRUCK, A., DIJKSTRA, H., International Organization (London 2019).

- RYAN, O., Animal Welfare and Economic Development: A Financial Institution Perspective. In J. D'SILVA, \& J. TURNER, Animals, Ethics and Trade: The Challenge of Animal Sentience (Oxon, 2006).

- RYLAND, D., Animal Welfare Governance : Global G.A.P. and the Search for External Legitimacy. Journal of Environmental Law, 30 (3) (2018), 453-482, p. 460, 466 and 467. DOI: https://doi.org/10.1093/jel/eqy015.

- SANKOFF, P., Canada's Experiment with Industry Self-Regulation in Agriculture: Radical Innovation or Means of Insulation? Canadian Journal of Comparative and Contemporary Law, 5(1) (2019), 299-348.

- SANTACOlOMA, P., Nexus Between Public and Private Food Standards: Main Issues and Perspectives. In A. MEYBECK, S. REDFERN, Voluntary Standards for Sustainable Food Systems: Challenges and Opportunities (Rome 2013).

- SCHERMERS, H.G., BLOKKER, N.M., International Institutional Law: Unity within Diversity (Leiden 2011).

- SEITZ, K., MARTENS, J., Philanthrolateralism: Private Funding and Corporate Influence in the United Nations, Global Policy, 8 (2017), 46-50. DOI: https://doi.org/10.1111/1758-5899.12448.

- SPRINGMANN, M., MASON-D’CROZ, D., ROBINSON, S., WIEBE, K., GODFRAY, H., RAYNER, M., \& al., Health-motivated Taxes on Red and Processed Meat: A Modelling Study on Optimal Tax Levels and Associated Health Impacts. PLoSONE, 13(11) (2018). DOI: https://doi.org/10.1371/journal.pone.0204139.

- STEINFELD, H., GERBER, P., WASSENAAR, T., CASTEL, V., ROSALES, M., \& DE HAAN, C., Livestock's Long Shadow, Environmental Issues and Options, (2006). Webpage: http://www.fao.org/3/a0701e/a0701e00.htm [Retrieved July 8, 2019].

- STUCKI, S., (Certified) Humane Violence? Animal Welfare Labels, the Ambivalence of Humanizing the Inhumane, and What International Humanitarian Law Has to Do with It, AJIL Unbound, 111 (2017), 277-281. DOI: https://doi.org/10.1017/aju.2017.65.

- SYKES, K., Globalization and the Animal Turn: How International Trade Law Contributes to Global Norms of Animal Protection. Transnational Environmental Law, 5(1) (2016), 55-79. DOI: https://doi.org/10.1017/S2047102516000054.

- SYKES, K., 'Nations Like Unto Yourselves': An Inquiry into the Status of a General Principle of International Law on Animal Welfare. 49 Canadian Yearbook of International Law, (2011), 3-49. DOI: https://doi.org/10.1017/S0069005800010316.

- TAYLOR, K., REGO ALVAREZ, L., Regulatory Drivers in the Last 20 Years Towards the Use of 
in Silico Techniques as Replacements to Animal Testing for Cosmetic-Related Substances, $\begin{array}{lllll}\text { Computational } & \text { Toxicology, } & 13 & \text { (2020), } & 100112 .\end{array}$ https://doi.org/10.1016/j.comtox.2019.100112.

- TODESCHINI, B. V., CORTIMIGLIA, M. N., CALlEGARO-DE-MENEZES, D., \& GHEZZI, A., Innovative and Sustainable Business Models in the Fashion Industry: Entrepreneurial Drivers, Opportunities, and Challenges. Business Horizons, 60(6) (2017), 759-770.

- TREVES, T., Diritto Internazionale, Problemi Fondamentali (Milano 2005).

- VAPNEK, J., CHAPMAN, M., Legislative and Regulatory Options for Animal Welfare, FAO Legislative Study 104 (2011).

- WILlETT, W. C., LUDWIG, D. S., Milk and Health, New England Journal of Medicine, 382 (2020), 644-54. DOI: https://doi.org/10.1056/NEJMra1903547.

- WILLETT, W., ROCKSTRÖM, J., LOKEN, B., et al.,Food in the Anthropocene: the EAT-Lancet Commission on Healthy Diets from Sustainable Food Systems. The Lancet, 393 (2019), 447- 492. DOI: https://doi.org/10.1016/S0140-6736(18)31788-4.

- YOUNG, O. R., The Architecture of Global Environmental Governance: Bringing Science to Bear on Policy. Global Environmental Politics, 8(1) (2008), 14-32. DOI: https://doi.org/10.1162/glep.2008.8.1.14.

\section{Legal Sources \\ Legislations \\ Treaties}

- Convention on International Trade in Endangered Species of Wild Fauna and Flora (CITES) (adopted March 3, 1973) 993 UNTS 243.

- Convention on the Conservation of Migratory Species of Wild Animals (CMS) (adopted June 23, 1979) 1651 UNTS 333.

- Convention on Biological Diversity (CBD) (adopted June 5, 1992) 1760 UNTS 79.

- Council of Europe, European Convention on the Protection of Animals Kept for Farming purposes (adopted March 3, 1976) ETS No.087.

- Council of Europe, European Convention for the Protection of Animals for Slaughter (adopted May 10, 1979) ETS No.102.

- Council of Europe, European Convention for the Protection of Vertebrate Animals used for Experimental and other Scientific Purposes (adopted March 18, 1986) ETS No.123.

- Council of Europe, European Convention for the Protection of Pet Animals (adopted November 13, 1987) ETS No.125.

- Council of Europe, European Convention for the Protection of Animals during International Transport (Revised) (adopted November 6, 2003) ETS No.193.

- General Agreement on Tariffs and Trade (GATT) (adopted October 30, 1947) 55 UNTS 194.

- Agreement on Technical Barriers to Trade (TBT) (adopted April 15, 1994) 1868 UNTS 120.

- Agreement on the Application of Sanitary and Phytosanitary Measures (SPS) (adopted April 15, 1994) 1867 UNTS 493.

\section{UN resolutions and declarations}

- Charter of the United Nations (adopted October 24, 1945), 1 UNTS 16.

- ECOSOC Resolution 1996/31 NGO related Resolution, UN Doc. E/RES/96/31 (25 July 1996).

- ECOSOC Resolution 2000/35 Report on the fourth session of the Intergovernmental Forum on Forests, UN Doc. E/RES/2000/35 (18 October 2000).

- ECOSOC Resolution 2015/33 International arrangement on forests beyond 2015, UN Doc. E/RES/2015/33 (22 July 2015).

- Nairobi Declaration on the Role and Mandate of UNEP (UNEP/Gc19/1/1997).

- UNGA Resolution 2997 (XXVII) Institutional and Financial Arrangements for International Environmental Cooperation, UN Doc. A/RES/2997(XXVII) (15 December 1972).

- UNGA Resolution 62/98 Non-legally binding instrument on all types of forests, UN Doc. A/RES/62/98 (17 December 2007). 


\section{EU Legislation}

- Commission Decision of 24 January 2017 Establishing the Commission Expert Group 'Platform on Animal Welfare' (Text with EEA relevance), C/2017/0280, OJ C 31, 31.1.2017, 61-66.

- Directive 2010/63 of the European Parliament and of the Council of 22 September 2010 on the protection of animals used for scientific purposes, OJ L 276, 20.10.2010, 33-79.

- European Parliament Resolution of 26 November 2015 on a New Animal Welfare Strategy for 20162020 (2015/2957(RSP)), OJ C 366, 27.10.2017, 149-150.

- European Parliament Resolution of 3 May 2018 on a Global Ban to End Animal Testing for Cosmetics (2017/2922(RSP)).

\section{National legislation}

- Federal Constitution of the Swiss Confederation. Webpage: https://www.admin.ch/opc/en/classified-compilation/19995395/index.html [Retrieved June 10, 2019].

- United States of America, Federal Animal Welfare Act. Webpage: https://www.govinfo.gov/content/pkg/USCODE-2015-title7/html/USCODE-2015-title7chap54.htm [Retrieved October 29, 2019].

\section{Precedents}

- Court of Appeal of Alberta, Reece v. Edmonton (City), 238 (CanLII) (Aug 04, 2011). Webpage: https://www.canlii.org/en/ab/abca/doc/2011/2011abca238/2011abca238.html\#_ftn28 [Retrieved: 19 April 2019].

- United States District Court, S.D. California, Tilikum v. SeaWorld Parks \& Ent., Inc., 842 F. Supp. 2d 1259 (S.D.Cal 2012) (U.S.).

- WTO Panel Report, US- Prohibition of Imports of Tuna and Tuna Products from Canada, WTO Doc. L/5198- 29S/91 (adopted February 22, 1982) [US-Tuna I, panel Report].

- WTO Panel Report, Canada- Measures Affecting Exports of Unprocessed Herring and Salmon, WTO Doc. L/6268- 35S/98 (adopted March 22, 1988) [Herring and Salmon, Panel Report].

- WTO Appellate Body Report. US- Import Prohibition of Certain Shrimp and Shrimp Products, , WTO Doc. WT/DS58/AB/R (adopted November 6, 1998) [Shrimp / Turtle I, AB Report].

- WTO Appellate Body Report, European Communities - Measures Prohibiting the Importation and Marketing of Seal Products, WTO Doc. WT/DS400/AB/R and WT/DS401/AB/R (adopted June 18, 2014) [EC - Seal Products, AB Report].

- WTO Panel Report, US-Restrictions on Imports of Tuna, WTO Doc. DS21/R-39S/155 [Tuna /Dolphin I, Panel Report].

- WTO Panel Report. US-Restrictions on Imports of Tuna, WTO Doc. DS29/R-39S/155 [Tuna /Dolphin II, Panel Report].

\section{Other Sources}

- ANDRIUKAITIS, V., Speech by Commissioner for Health and Food Safety Vytenis Andriukaitis at the European Parliament's Intergroup on the Welfare and Conservation of Animals in Strasbourg, France (2018, December 13). Webpage: https://ec.europa.eu/commission/commissioners/20142019/andriukaitis/announcements/speech-commissioner-health-and-food-safety-vytenisandriukaitis-european-parliaments-intergroup_en [Retrieved June 14, 2019].

- ANIMAL WELFARE INTERGROUP, Ending the Investment of International Finance Institutions into Intensive Animal Agriculture Outside the EU. Webpage: https://www.animalwelfareintergroup.eu/2017/02/09/ending-the-investment-of-internationalfinance-institutions-into-intensive-animal-agriculture-outside-the-eu/ [Retrieved August 19, 2019].

- ATRA, Une Agence de l'ONU Pour les Droits des Animaux. Webpage: https://www.atra.info/index.php/fr/396-une-agence-de-l-onu-pour-les-droits-des-animaux [Retrieved June 16, 2019].

- AXWORTHY, N., Danone CEO: Plant-Based to Become as Big as Dairy. Webpage: https://vegnews.com/2019/5/danone-ceo-plant-based-to-become-as-big-as-dairy [Retrieved August 
25, 2019].

- BOTHA, C. S., Tip Sheet: Key Changes to IFC's 2006 Good Practice Note on Animal Welfare and Summary of Outreach (2014). Webpage: https://www.ifc.org/wps/wcm/connect/62ab36e9-0cb44485-9752-

42b279469095/Animal_Welfare_Key_Changes_December_2014_final.pdf?MOD=AJPERES\&C $\mathrm{VID}=\mathrm{kJhvnjz.}$ [Retrieved August 13, 2019].

- CAMILLI, S., 8 Eco-Friendly Vegan Fabrics to Replace Wool - Without Plastic (February 21, 2019). Webpage: https://www.plantbasednews.org/lifestyle/8-eco-friendly-vegan-fabrics-replacewool-without-plastic [Retrieved August 26, 2019].

- CHIRAC, J., Discours de M. Jacques Chirac, Président de la République, sur la Coopération FrancoBritannique sur la Lutte Contre le Changement Climatique, le Développement Durable et la Protection de la Biodiversité (2003, November 24). Webpage: http://discours.viepublique.fr/notices/037000360.html [Retrieved August 21, 2019].

- COUNCIL OF THE EUROPEAN UNION, Outcome of The Council Meeting, 3464th Council meeting Agriculture and Fisheries. Brussels, (2016, 17 May).

- CPF, About the Collaborative Partnership on Forests. Webpage: http://www.cpfweb.org/73947/en/ [Retrieved June 26, 2019].

- DALTON, J., Supermarkets 'Trick Customers into Buying Chickens that Suffered in Industrial Farming'. Webpage: https://www.independent.co.uk/news/uk/home-news/chicken-supermarketoffers-industrial-farming-price-asda-aldi-lidl-tesco-sainsbury-morrisons-a8758861.html [Retrieved August 5, 2019].

- DELOITTE, Plant-based Alternatives Driving Industry M\&A., p.1. Webpage: https://www2.deloitte.com/content/dam/Deloitte/uk/Documents/consumer-business/deloitte-ukplant-based-alternatives.pdf [Retrieved October 26, 2019].

- EBRD, Environmental and Social Policy. Webpage: https://www.ebrd.com/news/publications/policies/environmental-and-social-policy-esp.html [Retrieved August 19, 2019].

- EBRD, MHP Regional. Webpage: https://www.ebrd.com/work-with-us/projects/psd/mhpbalkans.html [Retrieved August 19, 2019].

- EBRD, Project Finance. Webpage: https://www.ebrd.com/work-with-us/project-finance.htm [Retrieved August 19, 2019].

- ECOSOC, FAQ- Where Can I Find the Current Membership?. Webpage: https://www.un.org/ecosoc/en/FAQ\#currentmember [Retrieved August 23, 2019].

- Eurogroup for Animals. Webpage: https://www.eurogroupforanimals.org/key-achievements [Retrieved May 8, 2020].

- Eurogroup for Animals Model Animal Welfare Provisions for EU Trade Agreements- Trade \& Animal Welfare Project. Webpage: http://www.eurogroupforanimals.org/wp-content/uploads/E4AMAWP_Report-screenOKKKK.pdf. [Retrieved August 2, 2019].

- EUROPEAN COMMISSION, Launch of the EU Platform on Animal Welfare: Q\&A on Animal Welfare policy (2017, June 6). Webpage: http://europa.eu/rapid/press-release_MEMO-171426_en.htm [Retrieved June 15, 2019].

- EUROPEAN COMMISSION, Register of the Commission Expert Groups and Other Similar Entities, EU Platform on Animal Welfare. Webpage: https://ec.europa.eu/transparency/regexpert/index.cfm?do=groupDetail.groupDetail\&groupID=350 4 [Retrieved April 20, 2020].

- EUROPEAN COMMISSION, Special Eurobarometer 442: Attitudes of Europeans Towards Animal Welfare, (2016, March).

- EUROPEAN PARLIAMENT, Testing Cosmetics on Animals: MEPs Call for Worldwide Ban (2018, May 3). Webpage: http://www.europarl.europa.eu/news/en/pressroom/20180426IPR02613/testing-cosmetics-on-animals-meps-call-for-worldwide-ban [Retrieved May 20, 2019].

- EUROPEAN PARLIAMENT, Why MEPs Want a Global ban on Animal Testing for Cosmetics (2018, February 21). Webpage: http:/www.europarl.europa.eu/news/en/headlines/society/20180216STO98005/why-meps-want-aglobal-ban-on-animal-testing-for-cosmetics [Retrieved May 20, 2019].

- EUROPEAN PLATFORM ON ANIMAL WELFARE, Subgroup on Animal Transport. Webpage: https:/ec.europa.eu/food/animals/welfare/eu-platform-animal-welfare/thematic-sub- 
groups/animal-transport_en [Retrieved June 08, 2019].

- EUROPEAN PLATFORM ON ANIMAL WELFARE, Subgroup on Pigs. Webpage: https://ec.europa.eu/food/animals/welfare/eu-platform-animal-welfare/thematic-subgroups/pigs_en [Retrieved June 08, 2019].

- FAO, About the Gateway. Webpage: http://www.fao.org/ag/againfo/themes/animal-welfare/awabthegat/aw-whaistgate/en/ [Retrieved October 4, 2019].

- FAO, Livestock and the Environment. Webpage: http://www.fao.org/livestock-environment/en/ [Retrieved July 7, 2019].

- FAO, Livestock Solutions for Climate Change. Webpage: http://www.fao.org/3/a-i8098e.pdf [Retrieved October 4, 2019].

- FAO, Shaping the Future of Livestock Sustainably, Responsibly, Efficiently (The 10th Global Forum for Food and Agriculture GFFA), (2018, January). Webpage: http://www.fao.org/3/i8384en/I8384EN.pdf [Retrieved August 17, 2019].

- FAO, Sizing up Livestock Farming's Carbon Footprint: Tool Helps Livestock Farmers to Improve Productivity and Reduce Greenhouse Gas Emissions. Webpage: http://www.fao.org/news/story/en/item/429417/icode/ [Retrieved October 4, 2019].

- FAO, Sustainable Food and Agriculture. Webpage: http://www.fao.org/sustainability/en/ [Retrieved October 3, 2019].

- FAO, Tackling Climate Change Through Livestock. Webpage: http://www.fao.org/ag/againfo/resources/en/publications/tackling_climate_change/index.htm [Retrieved October 4, 2019].

- FAO, Transforming the Livestock Sector through the Sustainable Development Goals. Webpage: http://www.fao.org/3/ca1201en/CA1201EN.pdf [Retrieved October 4, 2019].

- FAO, OIE, WHO, Conducting National Joint Risk Assessment: a Tripartite Operational Tool. Webpage: https://extranet.who.int/sph/docs/file/3526 [Retrieved October 6, 2019].

- FAO, OIE, WHO, The FAO-OIE-WHO Collaboration: Sharing Responsibilities and Coordinating Global Activities to Address Health Risks at the Animal-Human-Ecosystems Interfaces. Webpage: https://www.who.int/foodsafety/zoonoses/final_concept_note_Hanoi.pdf?ua=1 [Retrieved October 6, 2019].

- FAO, WHO, About Codex Alimentarius. Webpage: http://www.fao.org/fao-whocodexalimentarius/about-codex/en/ [Retrieved October 4, 2019].

- FELSTED, A., Beyond Meat Should Take Notes From Juul. Webpage: https://www.bloomberg.com/opinion/articles/2019-08-23/big-food-s-embrace-of-fake-meat-facesobstacles-like-vaping [Retrieved August 25, 2019].

- GERHARDT, C., SUHLMANN, G., ZIEMSSEN, F., DONNAN, D., WARSCHUN, M., \& KÜHNLE, H., How Will Cultured Meat and Meat Alternatives Disrupt the Agricultural and Food Industry?, ATKearney. Webpage https://www.atkearney.com/documents/20152/2795757/How+Will+Cultured+Meat+and+Meat+Al ternatives+Disrupt+the+Agricultural+and+Food+Industry.pdf/06ec385b-63a1-71d2-c08151c07ab88ad1?t=1559860712714 [Retrieved 26 October, 2019].

- Global Animal Law Project Database Legislation. Webpage: https://www.globalanimallaw.org/database/national/index.html [Retrieved July 13, 2019].

- Global Animal Law Project Draft Declaration on Animal Welfare at Universal Level UDAW Proposal. Webpage: https://www.globalanimallaw.org/database/universal.html [Retrieved August 28, 2019].

- GLOBALG.A.P., Animal Welfare Add-on Module for Pigs/Finishers Checklist. Webpage: https://www.globalgap.org/.content/.galleries/documents/130214_gg_addon_aw_pg_cl_v1_0_protected_en.pdf [Retrieved August 2, 2019].

- GLOBALG.A.P., GlobalG.A.P. Animal Welfare Add-on. Webpage: https://www.globalgap.org/uk_en/for-producers/globalg.a.p.-add-on/animal-welfare/ [Retrieved August 2, 2019].

- IARC, Monographs on the Identification of Carcinogenic Hazards to Humans, (2019). Webpage: https://monographs.iarc.fr/list-of-classificationsm [Retrieved August 10, 2019].

- IARC, List of Classifications by Cancer Sites with Sufficient or Limited Evidence in Humans, Volumes 1 to 124, (2019, July 8). Webpage: https://monographs.iarc.fr/wpcontent/uploads/2019/07/Classifications_by_cancer_site.pdf [Retrieved October 7, 2019].

- IFC, Creating Business Opportunity through Improved Animal Welfare. Webpage: 
http://documents.worldbank.org/curated/en/494081468177535252/pdf/626320BRI0Crea00Box036 1488B0PUBLIC0.pdf [Retrieved August 15, 2019].

- IFC, Good Practice Note Improving Animal Welfare in Livestock Operations. Webpage: https://www.ifc.org/wps/wcm/connect/c39e4771-d5ae-441a-9942-

dfa4add8b679/IFC+Good+Practice+Note+Animal+Welfare+2014.pdf?MOD=AJPERES\&CVID= kGxNx5m. [Retrieved August 13, 2019].

- IFC, Performance Standard 6: Biodiversity Conservation and Sustainable Management of Living Natural https://www.ifc.org/wps/wcm/connect/topics_ext_content/ifc_external_corporate_site/sustainabilit y-at-ifc/policies-standards/performance-standards/ps6 [Retrieved August 15, 2019].

- ILO, Tripartite Constituents. Webpage: http://www.ilo.org/global/about-the-ilo/who-weare/tripartite-constituents/lang--en/index.htm [Retrieved July 28, 2019].

- IPCC, Climate Change and Land: an IPCC Special Report on Climate Change, Desertification, Land Degradation, Sustainable Land Management, Food Security, And Greenhouse Gas Fluxes in Terrestrial Ecosystems. Webpage: https://www.ipcc.ch/srccl-report-download-page/ [Retrieved August 26, 2019].

- LENNKH, S., COX, J. H., Model Animal Welfare Act. Webpage: http://worldanimal.net/images/stories/documents/Model_AWA/WAN-Model-Animal-WelfareAct.pdf [Retrieved August 2, 2019].

- NEW ZEALAND MINISTRY OF HEALTH, Sustainability and the Health Sector. Webpage: https://www.health.govt.nz/publication/sustainability-and-health-sector [Retrieved August 25, 2019].

- Non-human Rights Project. Webpage: https://www.nonhumanrights.org/ [Retrieved April 19, 2019].

- OECD, National Contact Points. Webpage: http://mneguidelines.oecd.org/ncps/ [Retrieved August 10, 2019].

- OIE, Bulletin, Animal welfare: an Asset for Livestock Production (2017). Webpage: https://www.oie.int/fileadmin/Home/eng/Publications_\&_Documentation/docs/pdf/bulletin/Bull_2 017-1-ENG.pdf [Retrieved October 2, 2019].

- OIE, Cooperation Agreements Between the OIE and Intergovernmental Organisations and Other International Nongovernmental Organisations. Webpage: https://www.oie.int/about-us/keytexts/cooperation-agreements/ [Retrieved May 9, 2020].

- OIE, Global Animal Welfare Strategy. Webpage: http:/oie.int/en/for-the-media/pressreleases/detail/article/adoption-of-the-first-oie-global-strategy-on-animal-welfare [Retrieved April 19, 2020].

- OIE, Terrestrial Animal Health Code. Webpage: http://www.oie.int/en/standard-setting/terrestrialcode/access-online/ [Retrieved June 20, 2019].

- OIPA, "L’ONU Apra agli Animali": le Associazioni Animaliste Riunite Presso la Sede delle Nazioni Unite a Ginevra Chiedono l'Apertura di un' Agenzia ONU per i Diritti Animali (2018, November 14). Webpage: https://www.oipa.org/italia/conferenza-ginevra/ [Retrieved April 16, 2020].

- ONE WELFARE, About One Welfare. Webpage: https://www.onewelfareworld.org/about.html [Retrieved October 2, 2019].

- ROCKEMAN, O., Plant-Based Sales Are Rising. If Only We Could Pick a Definition. Webpage: https://www.bloomberg.com/news/articles/2019-07-16/plant-based-sales-are-rising-if-only-wecould-pick-a-definition [Retrieved August 25, 2019].

- Sea Shepherd Operation Icefish News. Webpage: https://www.seashepherdglobal.org/ourcampaigns/icefish/latest-news/ [Retrieved July 28, 2019].

- SWABE, J., Animal Welfare Deserves Better from Investment Policy. Webpage: https://www.euractiv.com/section/euro-finance/opinion/animal-welfare-deserves-better-frominvestment-policy/ [Retrieved August 19, 2019].

- UBS, Plant-based Protein is Disrupting Meat Markets. Webpage: https://www.ubs.com/global/en/wealth-management/marketnews/financialeducation/article.1442540.html [Retrieved August 25, 2019].

- UN, Review of the United Nations Environment Programme and the Administrative Practices of Its Secretariat, Including the United Nations Office in Nairobi (UNON). Report of the SecretaryGeneral on the activities of the Office of Internal Oversight Services. (A/51/810) (1997).

- UNDP, Ethics @ UNDP. Webpage: 
https://www.undp.org/content/undp/en/home/accountability/ethics.html [Retrieved July 10, 2019].

- UNEP, Basel Convention Implementation \& Compliance Committee. Webpage: http://www.basel.int/TheConvention/ImplementationComplianceCommittee/Overview/tabid/2868/ Default.aspx [Retrieved July 27, 2019].

- UNEP, Coordinating Unit for the Mediterranean Action Plan Governing bodies. Webpage: https://web.unep.org/unepmap/who-we-are/institutional-framework/governing-bodies [Retrieved April 25, 2020].

- UNEP, Environment Fund. Webpage: https://www.unenvironment.org/about-unenvironment/funding/funding-facts/environment-fund [Retrieved July 8, 2019].

- UNEP, Environmental, Social and Economic Sustainability Framework. Webpage: https://www.unenvironment.org/about-un-environment/why-does-un-environmentmatter/environmental-social-and-economic [Retrieved July 8, 2019].

- UNEP, Environmental, Social and Economic Sustainability Framework (2015, January). Webpage: https://wedocs.unep.org/bitstream/handle/20.500.11822/8718/UNEP_environmental,_social_and_e conomic_sustainability_framework2015UNEP_Environmental_Social_and_Economic_Sustainabil ity_Framework.pdf.pdf? sequence $=2 \& a m p \% 3$ BisAllowed [Retrieved July 3, 2019].

- UNEP, Links to UNEP MEA Secretariats. Webpage: http://web.unep.org/divisions/delc/resources/links-unep-mea-secretariats [Retrieved August 9, 2019].

- UNEP, MEAs Support and Cooperation. Webpage: http://web.unep.org/divisions/delc/ourwork/env-governance-conventions/meas-support-and-cooperation [Retrieved August 9, 2019].

- UNEP, Rules of Procedure of The United Nations Environment Assembly of The United Nations Environment Programme. Webpage: https://www.unenvironment.org/cpr/environment-assemblyrules-procedure [Retrieved May 4, 2019].

- UNEP, Structure and Leadership. Webpage: https://www.unenvironment.org/about-unenvironment/why-does-un-environment-matter/structure-and-leadership [Retrieved July 4, 2019].

- UNEP, UN Environment Assembly and Governing Council. Webpage: http://web.unep.org/environmentassembly/un-environment-assembly-and-governing-council [Retrieved July 8, 2019].

- UNEP, UN Environment Divisions. Webpage: https://www.unenvironment.org/about-unenvironment/why-does-un-environment-matter/un-environment-divisions [Retrieved August 1, 2019].

- UNEP, UNEP Signs Agreement to Improve Monitoring of Hundreds of International Environmental Accords, 09 September 2013. Webpage: https://www.unenvironment.org/news-and-stories/pressrelease/unep-signs-agreement-improve-monitoring-hundreds-international [Retrieved May 4, 2020].

- UNEP, What We Do. Webpage: https://www.unenvironment.org/about-un-environment/what-wedo [Retrieved July 4, 2019].

- UNEP, Why Civil Society Matters. Webpage: https://www.unenvironment.org/civil-societyengagement/why-civil-society-matters [Retrieved August 20, 2019].

- UNFF, Ad-hoc Expert Groups. Webpage: https://www.un.org/esa/forests/forum/aheg/index.html [Retrieved April 25, 2020].

- UNFF, Forum Bureau. Webpage: https://www.un.org/esa/forests/forum/bureau/index.html [Retrieved June 10, 2019].

- UNFF, Global Objectives on Forests. Webpage: https://www.un.org/esa/forests/documents/globalobjectives/index.html [Retrieved April 25, 2020].

- UNFF, Major Groups Workplan. Webpage: https:/www.un.org/esa/forests/major-groups/majorgroups-workplan/index.html [Retrieved June 25, 2019].

- UNFF, Multi-Stakeholder Dialogue. Webpage: https://www.un.org/esa/forests/major-groups/multistakeholder-dialogue/index.html [Retrieved June 25, 2019].

- UNFF, UN Forum on Forests. Webpage: https://www.un.org/esa/forests/forum/index.html [Retrieved June 25, 2019].

- UNFF, UNFF Working Group and Special Session, Webpage: https://www.un.org/esa/forests/forum/2017-working-group-and-special-session/index.html [Retrieved April 25, 2020].

- UNOG, The United Nations \& Civil Society. Webpage: https://www.unog.ch/80256EE60057E07D/(httpHomepages)/2E72458FCDA07B16C1257ED7003 
13B19?OpenDocument [Retrieved July 28, 2019].

- WHO, Antimicrobial Resistance. Webpage: https://www.who.int/en/news-room/factsheets/detail/antimicrobial-resistance. [Retrieved October 7, 2019].

- WHO, Fiscal Policies for Diet and Prevention of Non-communicable Diseases. Webpage: https://apps.who.int/iris/bitstream/handle/10665/250131/9789241511247-

eng.pdf;jsessionid=4DF13B5CA5E8E23B299F67192BFF8DB8?sequence=1 [Retrieved October 7, 2019].

- WHO, Fiscal Policies for Diet and the Prevention of Non-Communicable Diseases. Webpage: https://www.who.int/dietphysicalactivity/publications/fiscal-policies-diet-prevention/en/ [Retrieved October 7, 2019].

- WHO, Global Action Plan for the Prevention and Control of Noncommunicable Diseases 20132020.

Webpage:

https://apps.who.int/iris/bitstream/handle/10665/94384/9789241506236_eng.pdf?sequence=1 [Retrieved October 7, 2019].

- WHO, Global Action Plan on Antimicrobial Resistance. Webpage: https://apps.who.int/iris/bitstream/handle/10665/193736/9789241509763_eng.pdf?sequence $=1$ [Retrieved October 6, 2019].

- WHO, Global Strategy on Diet, Physical Activity and Health. Webpage: https://www.who.int/dietphysicalactivity/diet/en/ [Retrieved October 7, 2019].

- WHO, Healthy Diet Fact Sheet N³94. Webpage: https://www.who.int/nutrition/publications/nutrientrequirements/healthy_diet_fact_sheet_394.pdf? ua $=1$ [Retrieved October 7, 2019].

- WHO, One Health. Webpage: https://www.who.int/features/qa/one-health/en [Retrieved, October 6, 2019].

- WICKER, A., Fashion's Long Hunt for the Perfect Vegan Leather. Webpage: https://www.voguebusiness.com/technology/vegan-faux-leather-stella-mccartney-prada-versace [Retrieved August 26, 2019].

- World Animal Net. Webpage: http://worldanimal.net/about [Retrieved August 2, 2019].

- WORLD BANK, Climate Smart Agriculture. Webpage: https://www.worldbank.org/en/topic/climate-smart-agriculture [Retrieved August 20, 2019].

- WORLD BANK, Moving Towards Sustainability: The Livestock Sector and the World Bank. Webpage: https://www.worldbank.org/en/topic/agriculture/brief/moving-towards-sustainabilitythe-livestock-sector-and-the-world-bank. [Retrieved August 18, 2019].

- WTO, Understanding the WTO: the Agreements Standards and safety. Webpage: https://www.wto.org/english/thewto_e/whatis_e/tif_e/agrm4_e.htm\#TRS [Retrieved October 8, 2019]. 